\title{
A REASSESSMENT OF HISTORICAL ATLANTIC BASIN TROPICAL CYCLONE ACTIVITY, 1700-1855
}

\author{
MICHAEL CHENOWETH \\ Independent Scholar, 6816 Ducketts Lane, Elkridge, Maryland 21075, USA \\ E-mail: m.chenoweth@att.net
}

\begin{abstract}
The chronological table of Atlantic basin tropical cyclones produced by Andrés Poey in 1855 is the foundation stone for present-day knowledge of historical Atlantic tropical cyclone activity. Subsequent researchers have used his table and built upon it, rejecting some of his entries, modifying others, and accepting the rest. A re-analysis of the 1700-1855 portion of Poey's original published list was made using historical newspaper accounts, weather diaries, and ships' logbooks. Of the 348 separate entries in Poey's original list, 149 were rejected and 198 accepted. Due to errors in dating and location, and the linking of separate entries as parts of the same storm, only 170 of the 198 accepted entries are unique storms. Thirteen undated storms of the remaining 170 are now dated. The authorities cited by Poey vary in their reliability. Of those cited 10 or more times, there was an average of one incorrect citation for every 3.1 correct citations. The most and least reliable authorities used by Poey are identified. An updated corrected chronology from all published sources is presented and includes 383 unique storms through 1855.
\end{abstract}

\section{Introduction}

Hurricanes and tropical storms in the Atlantic Ocean have threatened the inhabitants of the region for thousands of years. Written records from European witnesses to these storms date from the voyages of Christopher Columbus. The Spanish, French, English, Dutch, and other Europeans soon discovered the destructiveness of these storms and numerous accounts of the misfortunes brought to mariners and colonists were reported to their home countries.

When the first histories of the Caribbean colonies were written, hurricanes often were mentioned as important events in their history. Du Tertre (1667) mentioned twelve storms in the Lesser Antilles between 1642 and 1666 and his accounts are the main source we have for this time period. Other historians and almanac makers produced local chronologies over the years. Long (1774) apparently used one or more of these accounts to produce his modest list of hurricanes in the Caribbean region. Bryan Edwards's The history, civil and commercial, of the British Colonies in the West Indies first published in 1805, listed 18 separate storms. Poey (1855) considered Moreau de Jonnès's chronology of 1822 to be the first chronological list to attempt to document all of the known hurricanes in the West Indies dating back to 1495. Southey (1827) produced an important list of hurricanes. He also appears to be the first person to use the newspaper collections of the Reverend Dr. Charles Burney, purchased by the British Museum in 1818. This collection is the core of the 
British Library Newspaper Library collection today. Subsequent lists tended to rely heavily on pre-existing chronologies (Evans, 1848; Schomburgk, 1848; Johnston, 1855; Poey, 1855).

By the time Poey produced his 1855 chronology, the scientific investigation of tropical cyclones had been underway for more than three decades. Sir William Reid (1838, 1849), William Redfield (1831, 1854), and Henry Piddington (1848) were the most important researchers publishing their results at this time. None of them produced a chronology as such, but Poey drew on their work to supplement his list. He spent time in New York with Redfield copying out all of the notes on storms that Redfield possessed (Poey, 1855).

The list of Poey is a famous document for students of tropical meteorology. Since 1855, dozens of authors have used his list to produce their own updated lists of hurricanes and tropical storms. Tannehill (1938) used Poey's list (and those made since Poey's time) in his updating of the Atlantic basin hurricane history, omitting all storms in the months of December through May that were included in Poey's list. This was done because it was well known by this time that tropical cyclones in these months are very rare and the number too great in the historical record to be accurate. Subsequent work by Millás (1968) confirmed the dating errors from English sources prior to 1752 due to the late acceptance of the Gregorian calendar in England, relative to that of France and Spain. He also made the first critical analysis of the sources used by Poey, rejecting some storms, and including new storms made by his own research. Ludlum (1963) constructed the best chronology of landfalling tropical cyclones in the United States; a number of these storms can be associated with their earlier history in the Caribbean region. Fernandez-Partagás and Diaz (1995a,b, 1996a,b,c, 1997, 1999) make critical reference to Tannehill's (and, therefore, Poey for 1851 to 1855) chronology in their documentation of Atlantic tropical cyclones from 1851-1910. Their results are available on-line at http://www.aoml.noaa.gov/hrd/hurdat/hurdat_pub.html. Likewise, Rappaport and Fernandez-Partagás (1995) also drew on the same secondary sources. These sources are carried into the North Atlantic hurricane database known as HURDAT (Landsea et al., 2004), and an assessment of their reliability based on new information was made.

\section{The Need to Re-Analyze the Poey Chronology}

The importance of the Poey chronology lies in its persistent use for nearly 150 years. The accuracy of the historical record is important for many research communities. Attempts to reconstruct long-term variability in Atlantic basin hurricanes (e.g., Walsh and Reading, 1991) assume that the available record in populated regions of the Caribbean is largely complete since about 1650 , which is highly unlikely. Boose et al. (2004) use some of these sources in their work on hurricane impacts on Puerto Rican tropical rain forest ecology. Paleohurricane studies using proxy 
data are dependent on accurate historical records for evaluating strike probabilities over time (Liu, 2004; Donnelly et al., 2001; Liu and Fearn, 2000). The insurance industry also requires accurate information of hurricane occurrences (Malmquist, 1998; Elsner and Kara, 1999).

The use of primary source documents is the most accurate way to rediscover historical tropical cyclones. Redfield, Reid and Piddington all used such sources, particularly ships' logbooks, to track tropical cyclones in different parts of the world. More recently, Ludlum (1963), Fernandez-Partagás and Diaz (1995a,b, 1996a,b, 1997, 1999), Rappaport and Fernandez-Partagás (1995), Rappaport and Ruffman (1999), Sandrik and Landsea (2003), Chenoweth (2003), Mock (2004) and GarciaHerrera et al. (2005) have used a variety of primary source documents to reconstruct individual storms and local time series of tropical storms and hurricanes. During the course of investigating Jamaican tropical cyclones, evidence was found that many of the accepted accounts of historical tropical cyclones were in error (Chenoweth, 2003). The high frequency of errors led to a more detailed search for new information to determine the reliability of the Poey chronology, and subsequent work that has relied on Poey and/or the sources he consulted.

\section{Poey's Record}

The original list of Poey, published in the Journal of the Royal Geographical Society in 1855 , contains 401 separate entries of "cyclonic hurricanes" from 1493 through 1855. The dates, localities affected, and the authorities cited are included, along with footnotes of additional information and analysis. Poey suspected, usually correctly, that some individual entries were probably related to adjacent entries in the same year but he made no effort to narrow down his original count. He also notes conflicts on dates of storms between different sources. Dozens of authorities are cited; many provide information on only one hurricane. Only fifteen sources provide ten or more different entries. Poey did not investigate the degree to which later authors used the same sources. The result is the apparent large number of citations for individual storms, which ultimately derive from a single or very small number of sources. The reliability of the most important sources used by Poey will be documented in Section 6.

\section{Source Documents}

The original source for Atlantic basin hurricanes is still not always discernible. Judging from sources mentioned in Poey, historians most often used secondary sources for the majority of cases in the 18th and early 19th centuries. The ultimate sources are most often newspaper accounts. Different newspapers often used the same original colonial newspaper account. The exact source may not be known, but 
in such instances when details are given they can be compared with the newspaper accounts and a source confirmed. Millás (1968) quotes the Annual Register and The Gentleman's Magazine as two sources that were used by early hurricane chroniclers in the mid and late 18th century. These were indeed used but both tended to provide a reduced and edited version that appeared in full in other contemporary English newspapers. Private letters were often published in newspapers giving additional information. Major disasters to naval fleets often received extensive press attention in the official government accounts of European countries. Ship logbook accounts become more frequent in appearance in 19th century newspapers. Mariners often brought accounts of storms encountered at sea to the press in ports throughout the region. Redfield, Reid and Piddington used such press clippings to gather much of their marine data.

The main weakness of newspaper accounts, particularly those carrying accounts of storms elsewhere, is the risk of inaccurate information being propagated any number of ways. Incorrect information passed from the original source, or through misunderstanding by the reporter, could introduce an error in fact at the first point. Typeset could be incorrectly inserted by a hurried or inattentive typesetter. The newspaper item could be picked up by a neighboring newspaper and garbled and this could then be picked up by other sources. Some accounts omit dates and locations, or are vague about the exact time and place of a storm. In some instances, information that is known to be possibly vague is later found to be in error. This requires a more thorough search of newspapers beyond an initial report. A good example of this is reporting on a 1779 tropical cyclone that passed some distance off the South Carolina coast in September of that year. Millás (1968) places the storm near Charles Town, the island of Nevis in the Lesser Antilles, when in fact his source is discussing Charles Town [Charleston] in South Carolina. Information in the original accounts is vague, involving the search of the British Navy for the French Fleet intent on invading the American colonies during the American Revolutionary War. Hence, Millás made a bad assumption based only on the port's name and introduced a major error into his chronology.

Most Caribbean newspapers from the 18th century no longer exist. Accounts must be drawn from other newspapers that republished their original accounts. Another primary source document is ships' logbooks, which remain in great numbers for the entire 1700-1855 period (Chenoweth, 1996; see also www.nmm.ac.uk for an excellent introduction to ships' logbooks in the Climate of the World's Oceans (CLIWOC) section). These records fill in the newspaper gap and are extremely useful for verifying the existence of a tropical cyclone. They provide wind and weather data at sub-hourly to daily resolution, which is invaluable in determining prevailing synoptic weather conditions. Their main limitation can be their failure to make any mention of land-based storm damage, which newspaper accounts provide in greater detail. In fact, both records are excellent sources that add to the other. When a newspaper record is unavailable, the logbook record must be scrutinized 
more closely to infer the potential damage done from the weather reports included in the logbook.

While newspapers and logbooks are important sources of information it should be pointed out that many other archive sources remain to be examined. The huge record of the British Colonial Office provides accounts from all of the colonies on a wide range of topics concerning the important political and economic affairs of the colonies, including storm damage from hurricanes. Likewise, similar Spanish colonial records are beginning to yield invaluable information on Atlantic hurricanes, especially in the Spanish colonies (e.g. Garcia-Herrera et al., 2005). In terms of length of record, Spanish records have potential to provide the longest local time series. A truly comprehensive record of Atlantic hurricanes will require examination of all European and former colonial archives.

\section{Data and Methods}

Newspaper accounts for the period 1700-1855 were consulted from newspaper archives in the U.S. Library of Congress, Washington, DC, the University of Maryland, College Park, Maryland, the British Library Newspaper Library, in London as well as newspapers included in the records of the Colonial Office in the UK National Archives, London. Scores of different newspapers were used and are too numerous to enumerate here. A few of the titles read include The Boston News Letter (1705-1775), The Pennsylvania Gazette (1729-1776, 1783-1792); Lloyd's List (1740-1855), London Times (1785-1855), Jamaica Royal Gazette (1778-1781; 1811-1838); The Royal Gazette and Bahama Advertiser (1804-1811, 1813-1837); Diario de la Marina (Havana) (1844-1855) to name only a few newspapers. A total of 5,606 newspaper accounts were used. Due to duplication of original sources in other newspapers, the estimated number of "unique" accounts is 3,447, after adjusting for duplications and probable same sources being used in other press accounts. British Navy ships' logbooks were used to supplement newspaper coverage. These logbooks are available at the U.K. National Archives in London. Additional logbook data were obtained from other archives in the United States archives (US National Archives, Washington, DC; Mystic Seaport Museum, Mystic, Connecticut; Old Dartmouth Whaling Museum, New Bedford, Massachusetts; Peabody Essex Museum, Salem, Massachusetts). Four hundred and fifty-six logbook records were used in the re-analysis of the Poey chronology. Precisely dated logbook entries allow for improved temporal and spatial continuity in tracking individual storms and detecting potential associations (or their absence) in the mapping and plotting of individual tropical cyclones. Details in press coverage were compared with accounts published in Poey (1855), Ludlum (1963), Millás (1968), Mock (2004) and Garcia-Herrera et al. (2005). In a number of instances, the same (unattributed) newspaper account that was cited 
in the original source was found in the English press. Such sources are likely the original record from which all subsequent accounts are originally based. Table I lists the original Poey entries, with a column indicating whether or not the storm was accepted or rejected and another column indicating the reason for its status.

The period 1700-1855 was chosen for several reasons. First, the great majority of the storms listed by Poey occur after 1700. Secondly, English language sources are easily available and abundant from 1700 onward; newspapers in England began to proliferate in number after 1695 , following the end of royal licensing with the first daily newspaper established in 1703 (Rogers, 2003). Thirdly, newspaper publishing in North America began on a regular basis about the same time. Fourth, logbook records are abundant since 1670 from English sources. Using the Poey record, these primary sources were used to check the chronology for accuracy in the date and location of tropical cyclones.

The Poey record was entered into a database. This record was compared against a separate record of tropical cyclones from original sources cited above, along with daily weather records kept in Jamaica from 1750-1786 (Chenoweth, 2003), St. Eustatia from 1787-1793 (Fahlberg MS Met Obs obtained from the Royal Academy of Sweden), Nassau, Bahamas from 1812-1840 (Chenoweth, 1998), and other shorter weather records. Together, they constitute the most comprehensive collection of daily weather data from the tropical Atlantic for this time period.

Storms included in Poey's list were considered to be in error for the following reasons. (1) absence of independent evidence from primary sources; (2) incorrect years, but correct date; (3) correct dating, but incorrect location; (4) cited source failed to mention weather as a cause of a disaster; (5) correct day of month, but wrong month; (6) date and location are correct, but weather was not associated with a tropical cyclone (e.g., heavy flooding from a thunderstorm).

Storms were accepted even when some errors were evident. These include (1) correct location and month (or just year) without a given day of month which fits, or could plausibly link with independent data; (2) deviations of plus or minus one day from the actual date of maximum storm impact; (3) incorrectly linked storms, but based on otherwise accurate accounts; (4) dates given in old style Julian form, but correct when converted to the modern Gregorian calendar.

Reasons for rejection of the storms were most frequently due to garbled dates. Very frequently the year was incorrect, often offset by a single year. In some instances, the digits in the date were transposed or omitted. Errors in the month, but with a correct day, were common; a few errors were off by one week. This indicates that the original source may have made a reference to the day of the week of the storm, which was correct, but the day of the month was in error for some reason. In some instances, the date was correct, but the location completely in error ("July 27, 1805 - Jamaica" as cited by Poey from Schomburgk's work is actually a storm encountered in the North Atlantic on this date by the fleet sailing from 
REASSESSMENT OF HISTORICAL ATLANTIC TROPICAL CYCLONES

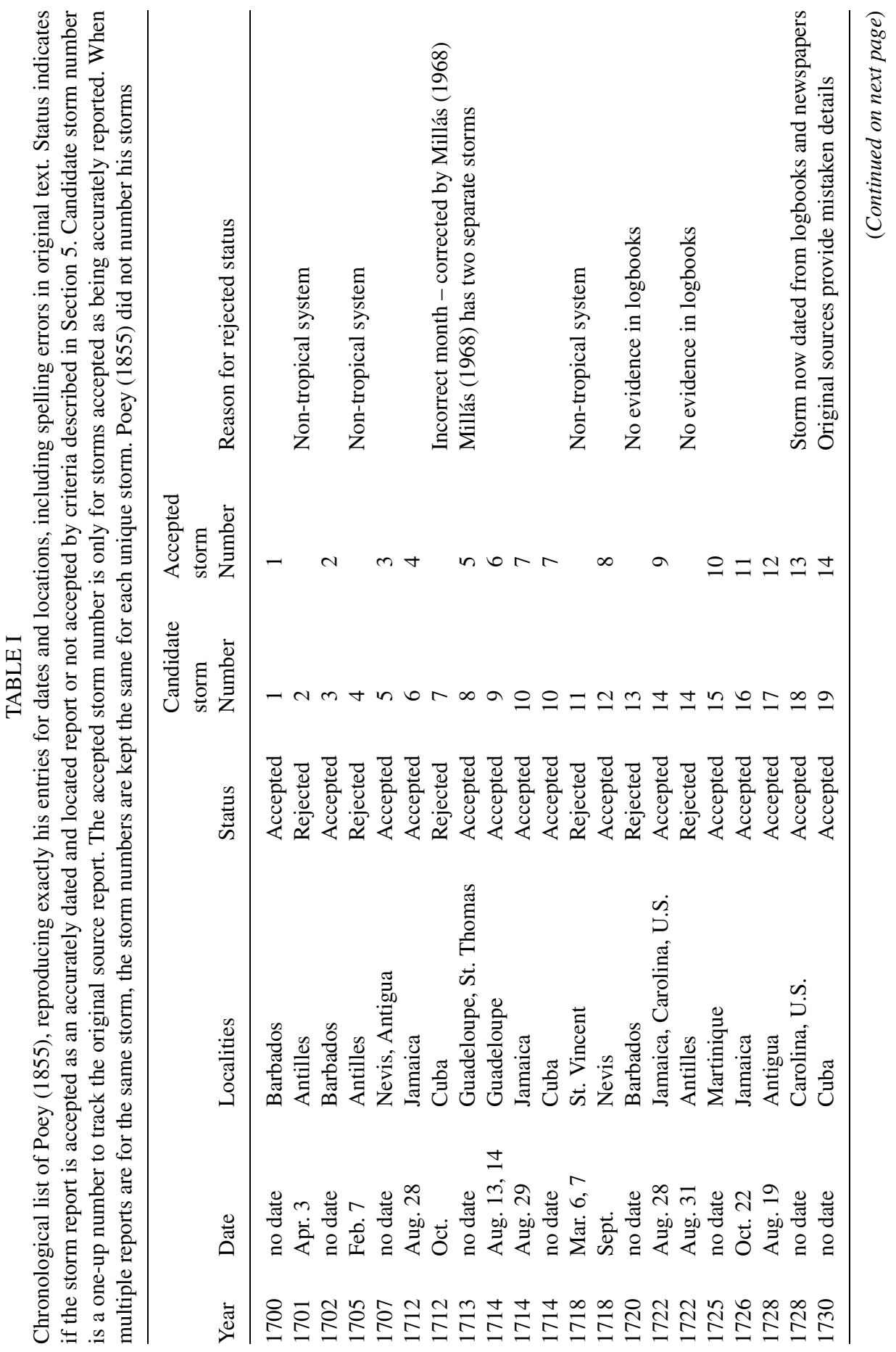




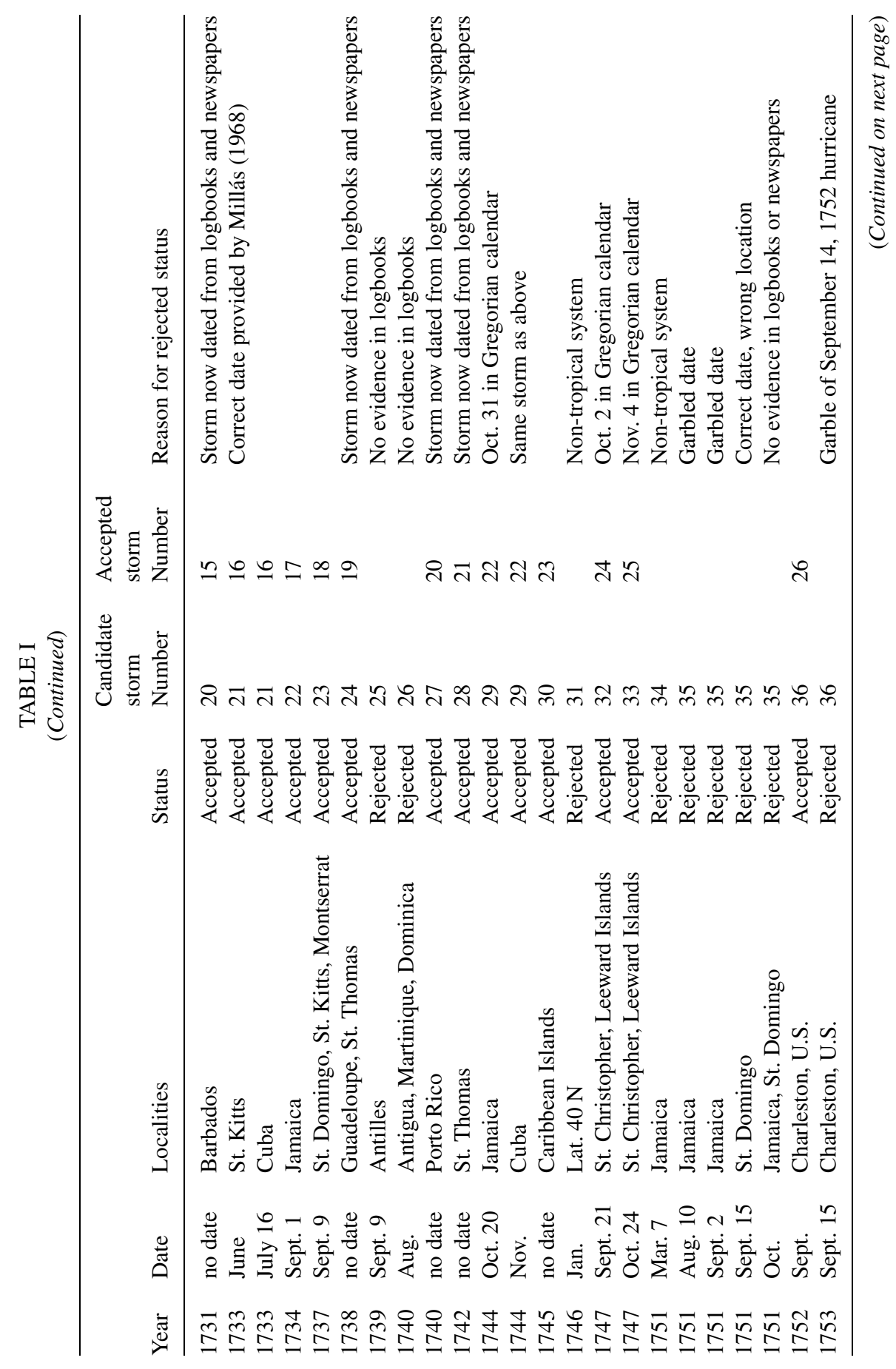


REASSESSMENT OF HISTORICAL ATLANTIC TROPICAL CYCLONES

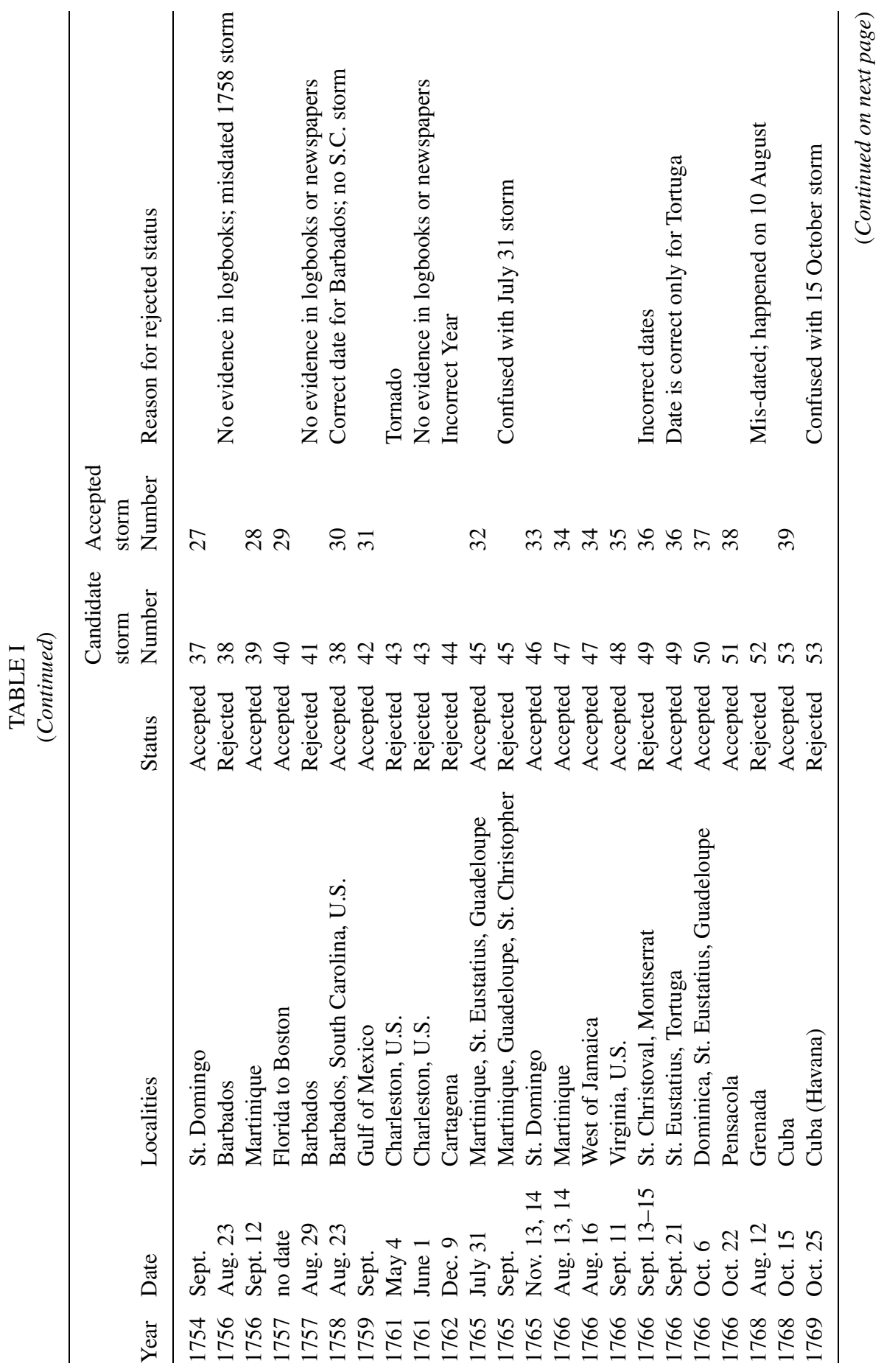




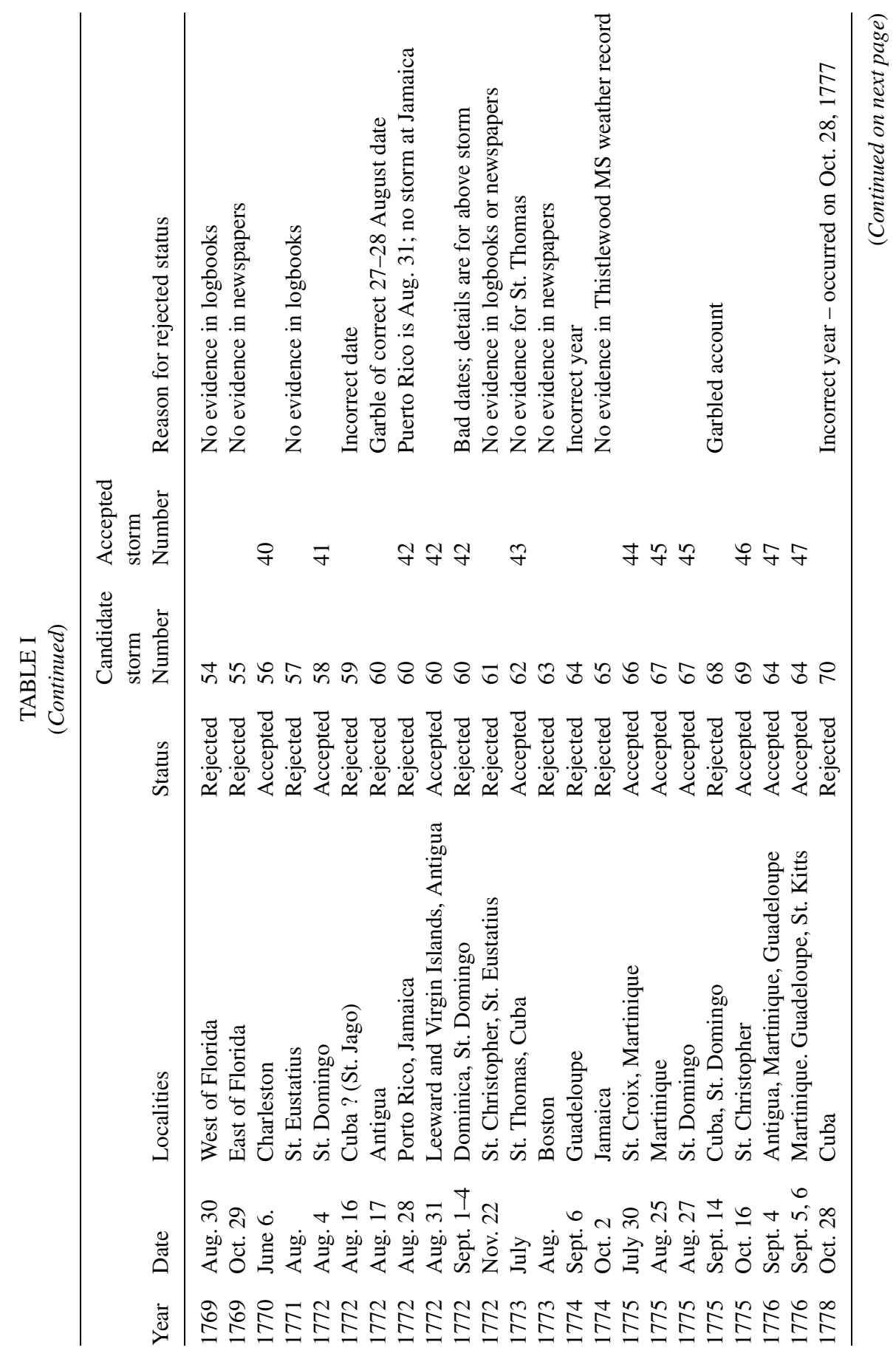


REASSESSMENT OF HISTORICAL ATLANTIC TROPICAL CYCLONES

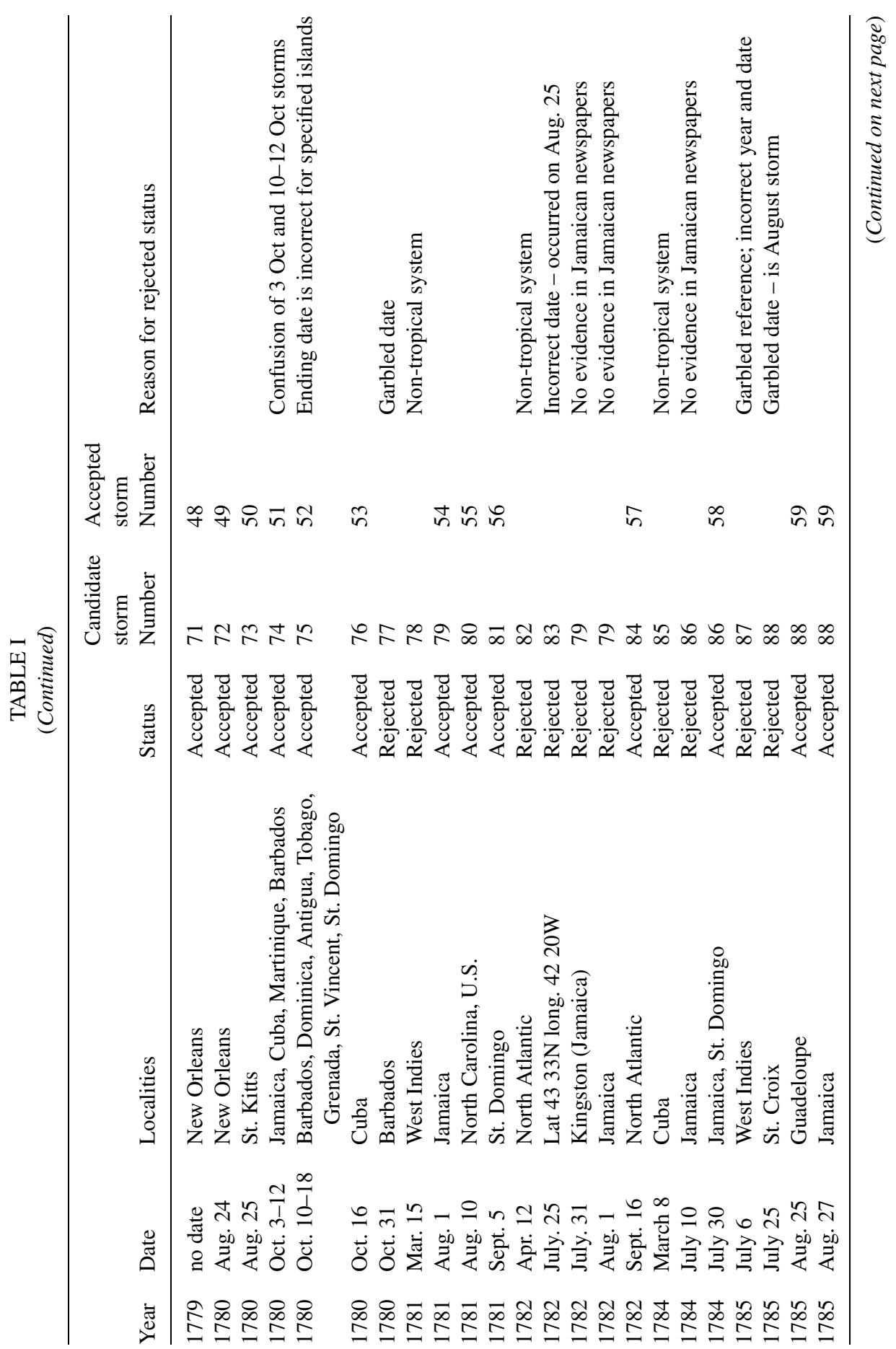


M. CHENOWETH

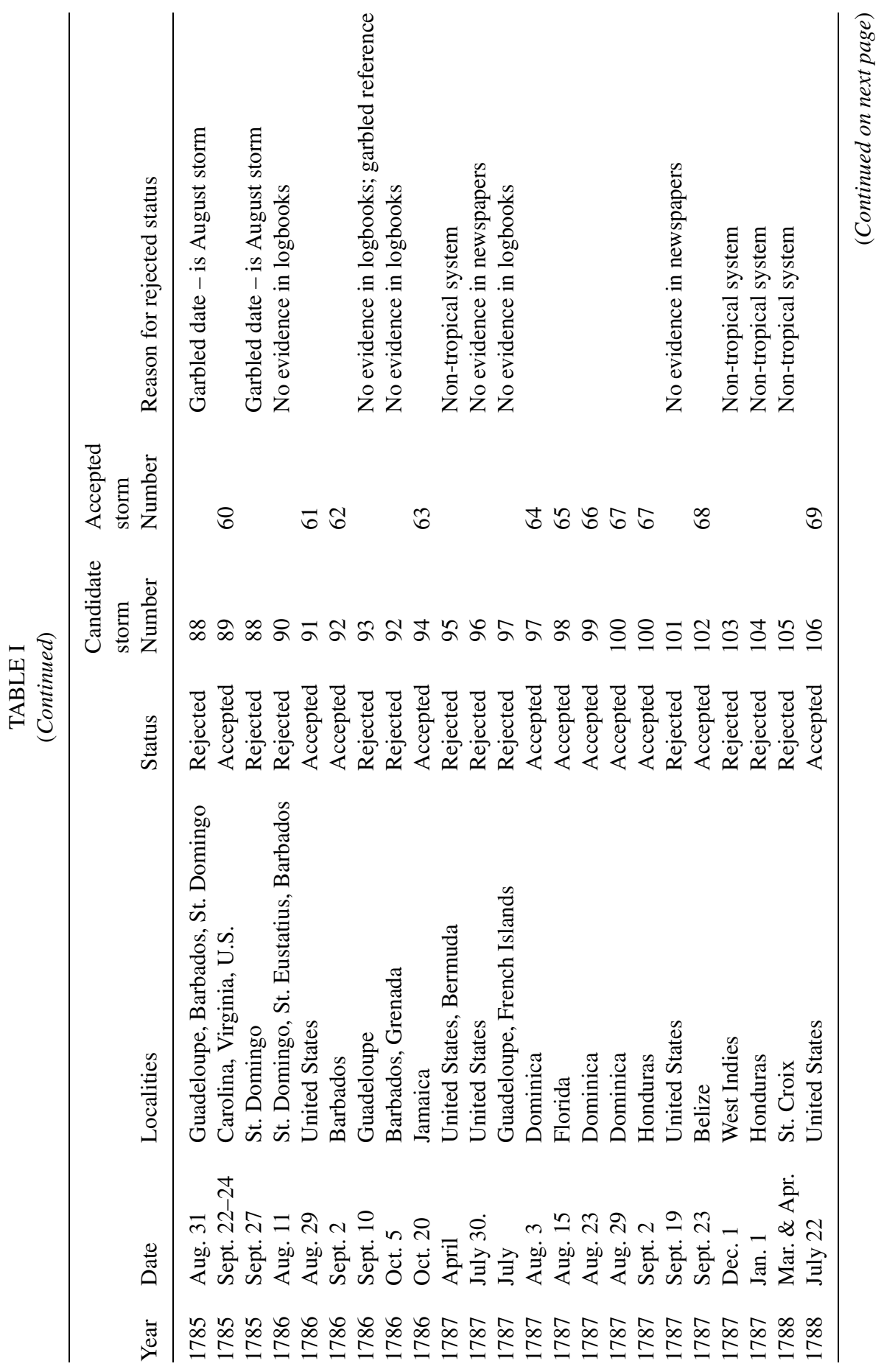


REASSESSMENT OF HISTORICAL ATLANTIC TROPICAL CYCLONES

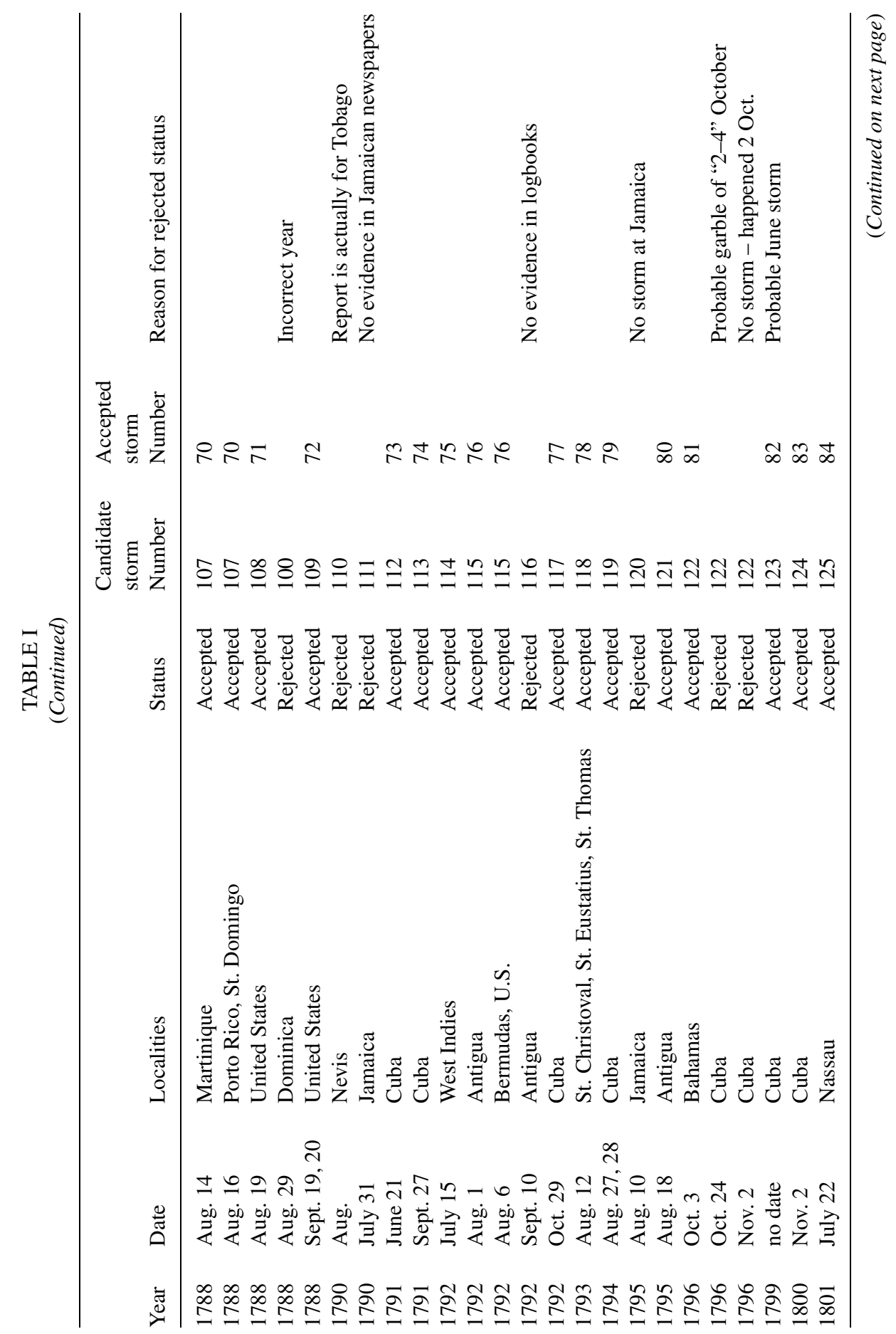


M. CHENOWETH

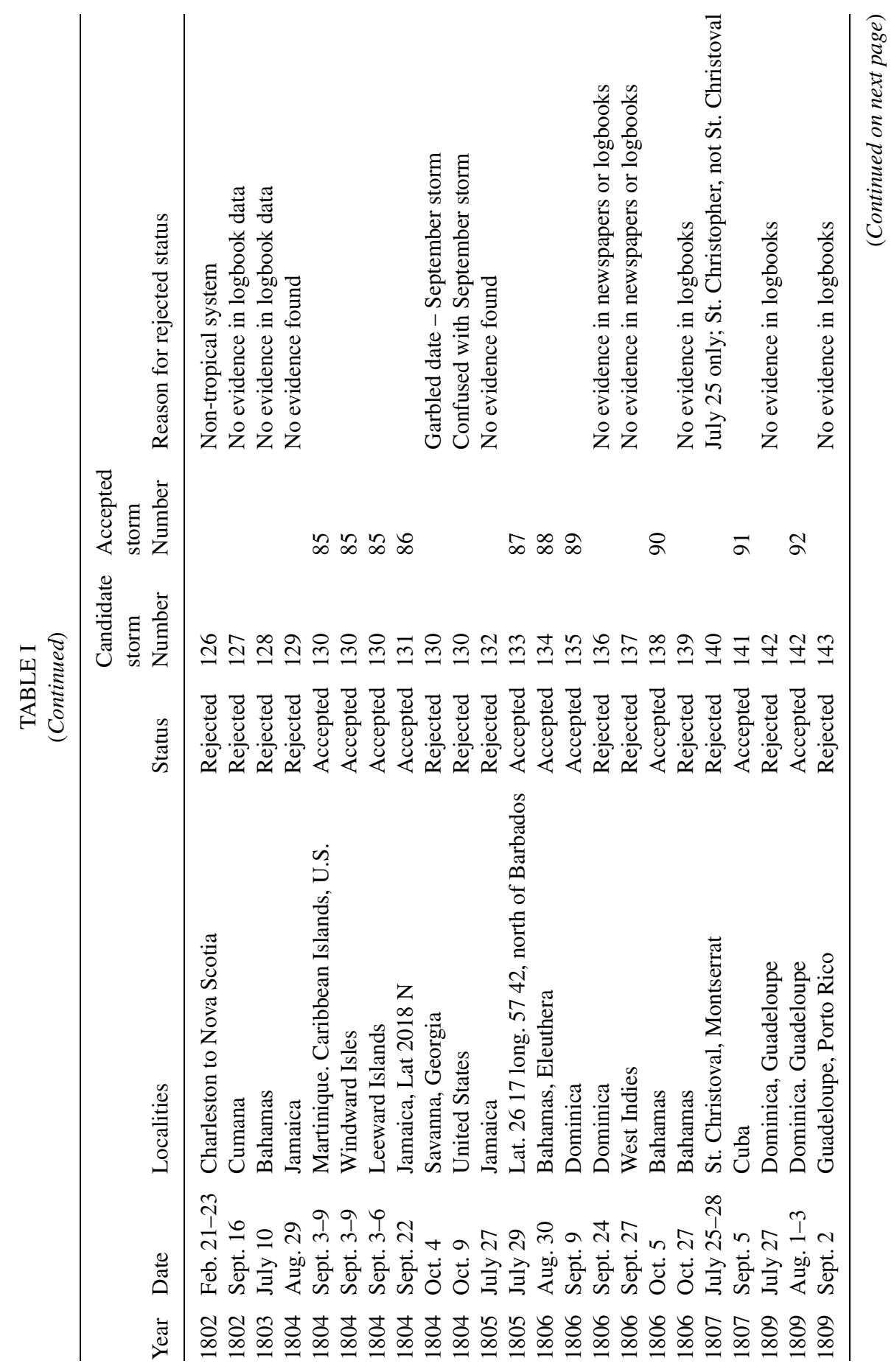


REASSESSMENT OF HISTORICAL ATLANTIC TROPICAL CYCLONES

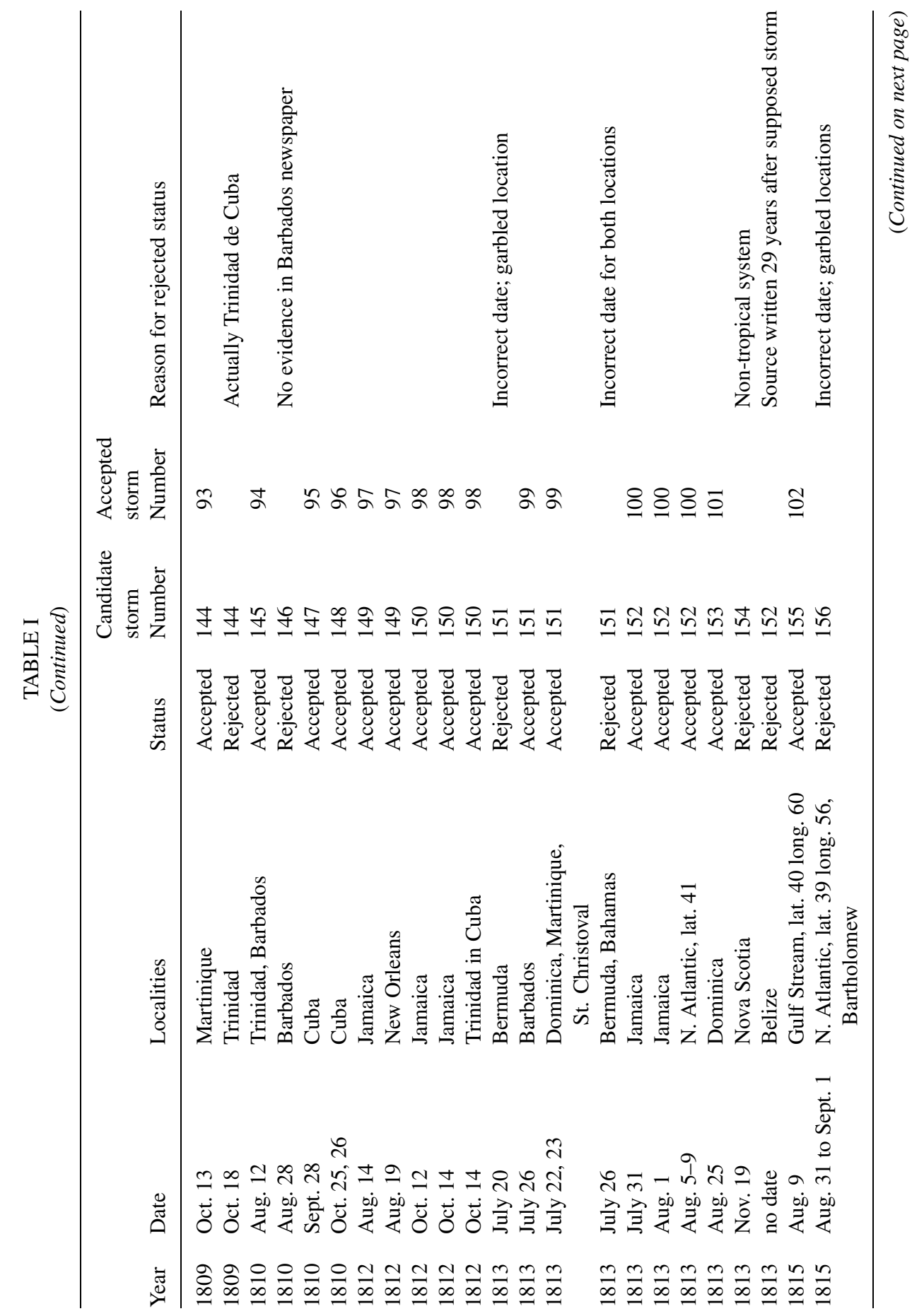


M. CHENOWETH

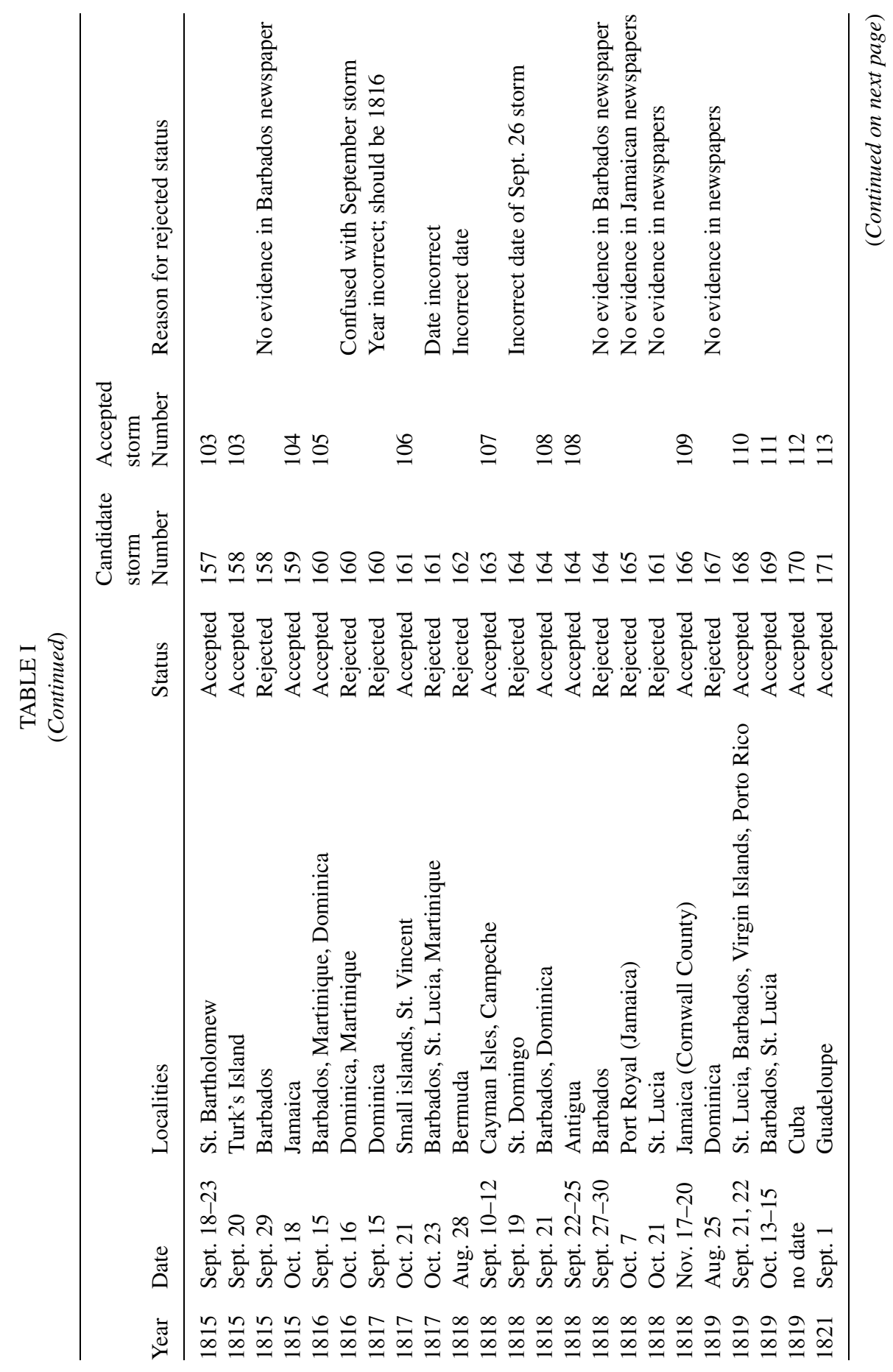


REASSESSMENT OF HISTORICAL ATLANTIC TROPICAL CYCLONES

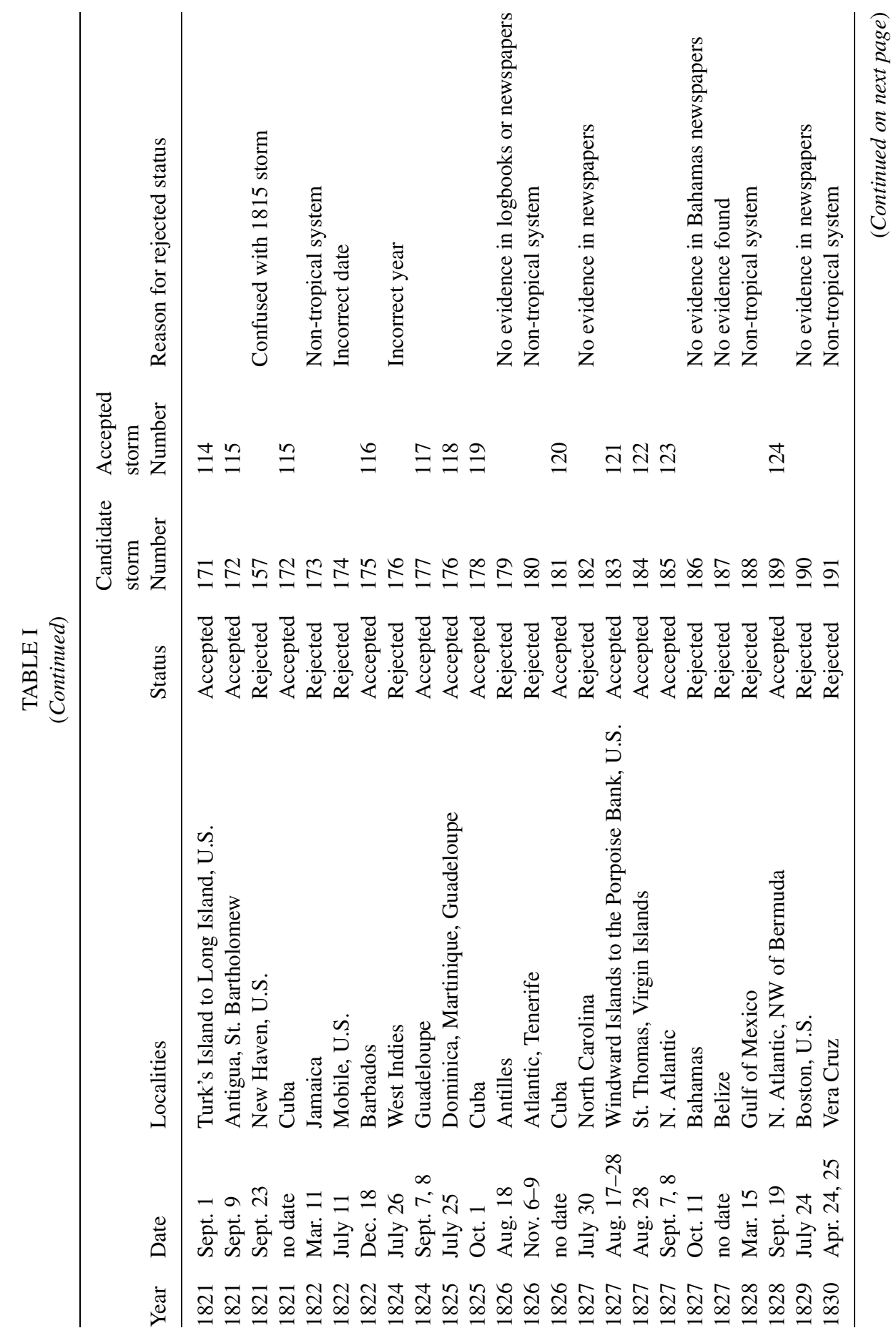


M. CHENOWETH

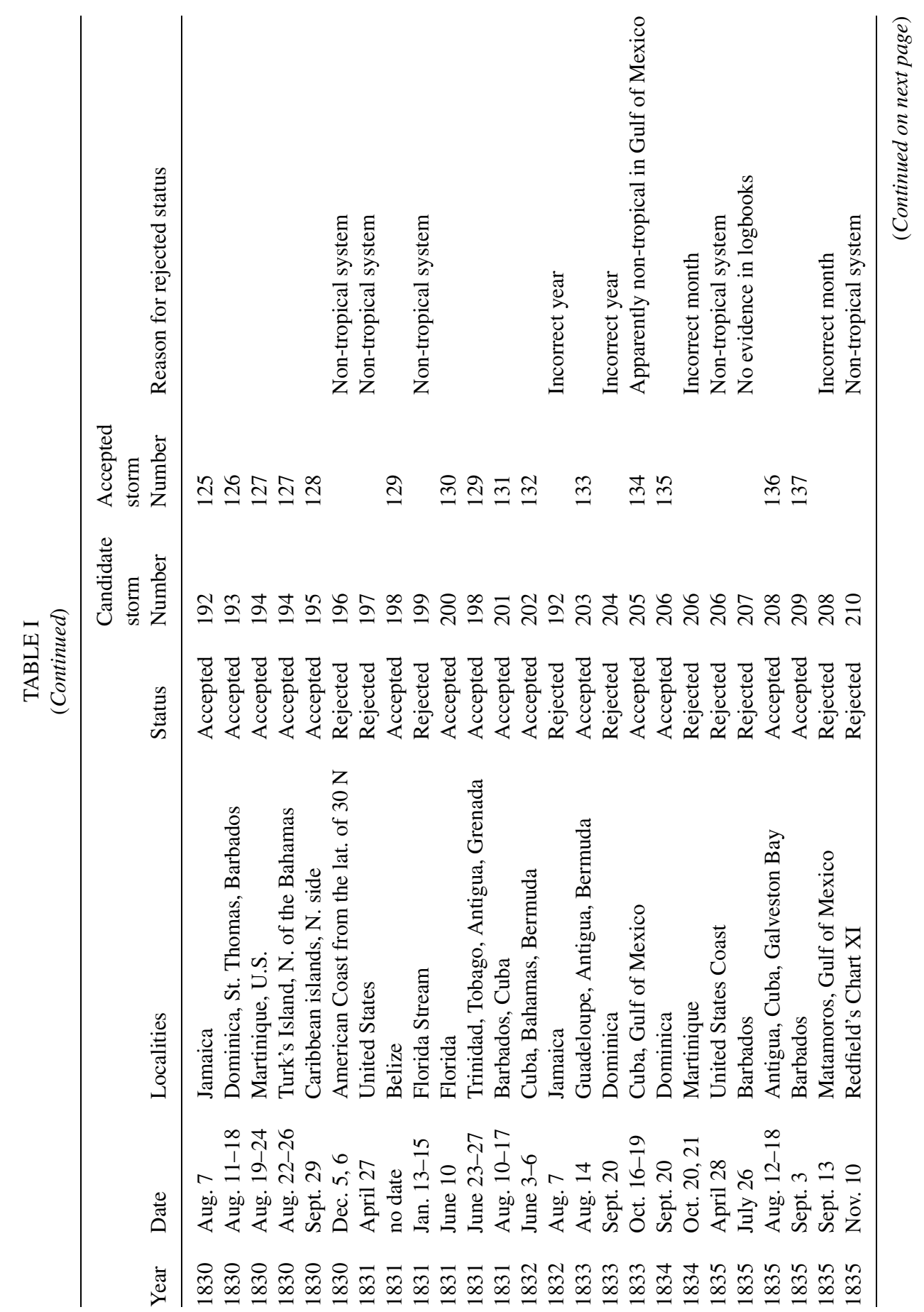


REASSESSMENT OF HISTORICAL ATLANTIC TROPICAL CYCLONES

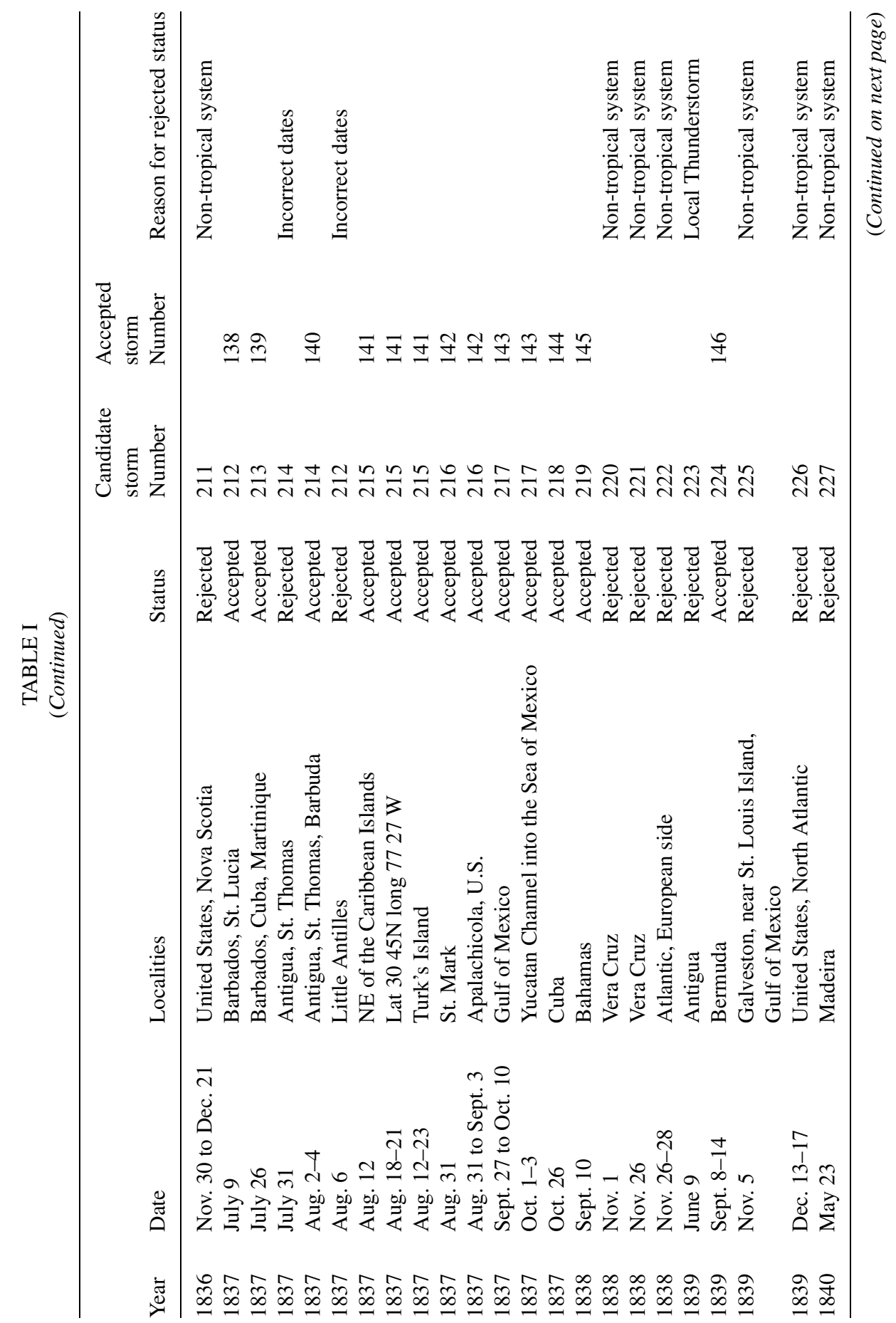


M. CHENOWETH

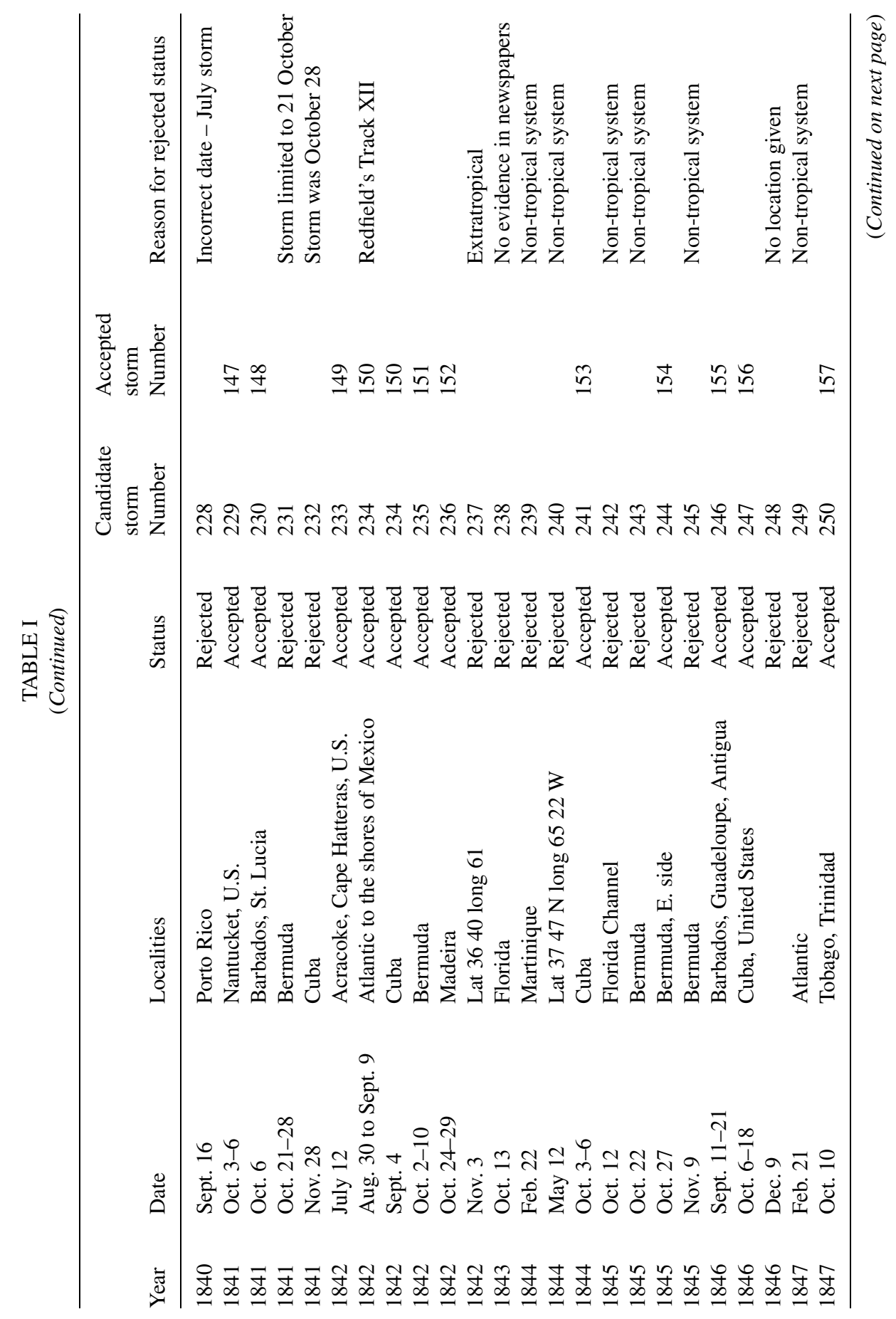


REASSESSMENT OF HISTORICAL ATLANTIC TROPICAL CYCLONES

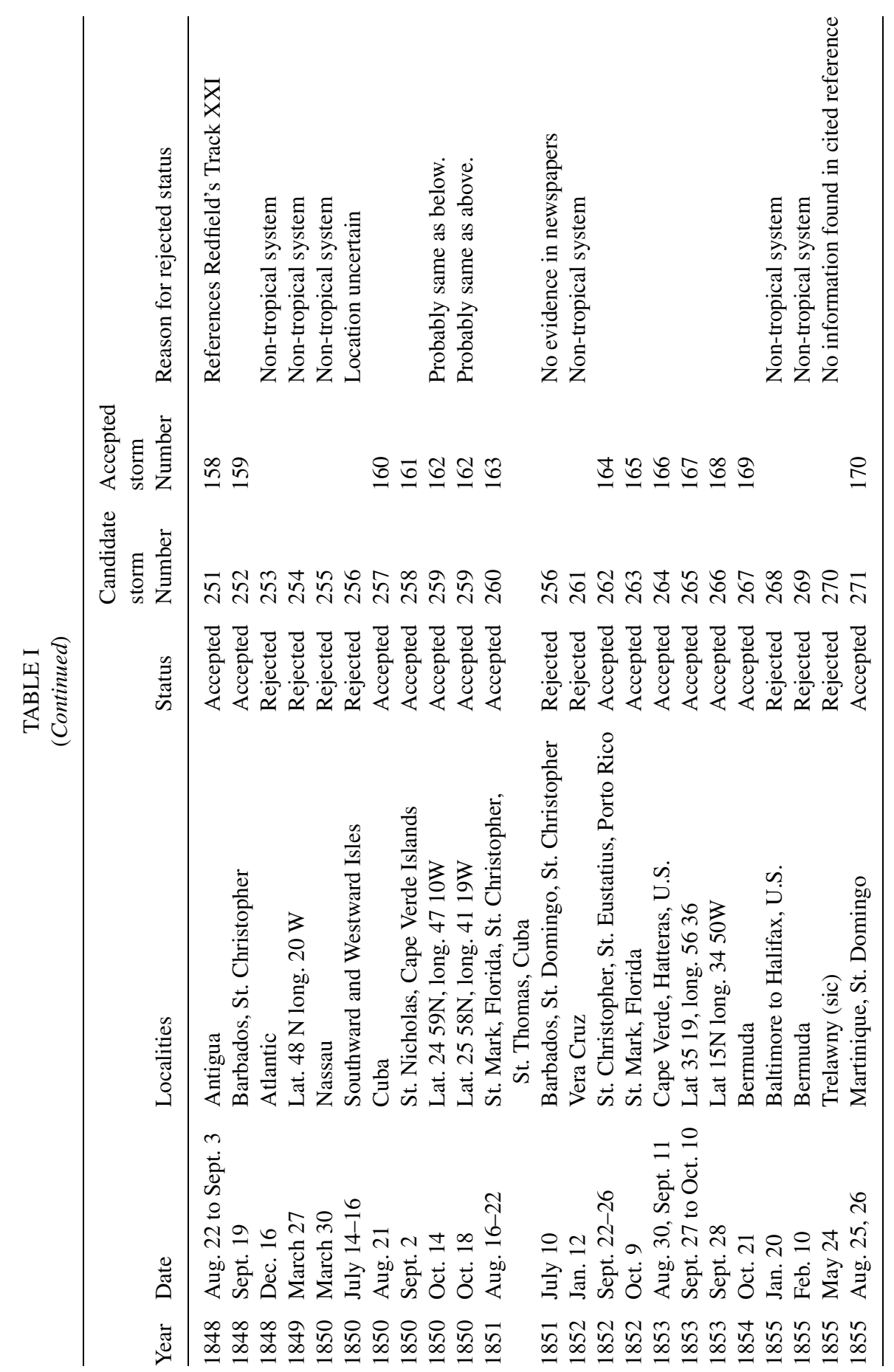


Jamaica). Some entries are rejected because precisely dated primary sources show no evidence for a storm at the cited location.

A number of storm entries in Poey refer to the same storm. The newly gathered reports allowed a number of entries to be linked, thereby reducing the total number of storms that were ultimately accepted. Likewise, the number of rejected entries is actually larger than the actual number of rejected storms, because the year was incorrect and could be connected with a storm the year before or after on the same date at the same location as well as multiple misdated, but otherwise identical, storm reports. A good example of this latter error can be found in the listings for 1785 (Table I).

Determination of the nature of storms and gales require knowledge of modern synoptic meteorology. A discussion of these challenges is provided by Rappaport and Fernandez-Partagás (1995) available at the web site http://www.nhc.noaa.gov/ pastdeadly2.shtml. Methods for locating the approximate center of a tropical cyclone such as that described in Landsea et al. (2004) were used. Criteria for inclusion in the new final compilation included evidence consistent with a tropical storm or hurricane (tropical depressions are not included in this list). The evidence for each storm which can be consistently applied throughout the 1700-1855 period includes one or more of the following: evidence of a closed surface low pressure center; gradual wind shifts consistent with the apparent motion of the storm; sustained gale force or greater winds; description of sea states and coastal storm surges; barometric pressure (when available and reliable); descriptive accounts which are consistent with the features of tropical cyclones (e.g., strong wind squalls interspersed with periods of much lighter winds that are not associated with local thunderstorm activity); the taking of action by the crew of a ship in the furling and reefing of sails, use of anchors, and other protective measures that are consistent with gale force winds; damage reports on land to natural and man-made structures that are caused by wind damage and not solely by the action of flood waters or heavy rains; protective measures taken on land in preparation for what is believed to be an oncoming tropical cyclone. The last point is to emphasize the direct eyewitness reactions to the weather that we can only reconstruct from written records, even if the eyewitnesses were fortunate enough to be by-passed by an anticipated storm. Candidate storms from all months of the year were examined. Most storms in the months of December through May were rejected because they were determined to be extra-tropical in nature, although powerful and producing hurricane force winds in some instances. A good example of such a rejected storm is the storm of 20 January 1855, which was actually a major winter snowstorm that affected the eastern coast of the United States. An example of an accepted out-ofseason storm is that of December 19-20, 1822, which is copiously documented in newspaper accounts of the Lesser Antilles, and probably originated as an extratropical low that moved southward into the region and transformed into a tropical cyclone. 
REASSESSMENT OF HISTORICAL ATLANTIC TROPICAL CYCLONES

TABLE II

Reliability of sources used by Poey to construct his chronology (1700-1855 only)

\begin{tabular}{lrccl}
\hline Authority cited by Poey & Rejected & Accepted & Total & $\begin{array}{l}\text { Ratio of rejected } \\
\text { to accepted storms }\end{array}$ \\
\hline Edwards (1805) & 1 & 17 & 18 & $1: 17$ \\
Southey (1827) & 5 & 30 & 35 & $1: 6$ \\
Warden & 3 & 18 & 21 & $1: 6$ \\
Morreau de Jonnès (1822) & 5 & 29 & 34 & $1: 5.8$ \\
Annual Register (London) & 2 & 11 & 13 & $1: 5.5$ \\
Johnson (1855) & 12 & 54 & 66 & $1: 4.5$ \\
Schomburgk (1848) & 20 & 86 & 106 & $1: 4.3$ \\
Thomson & 2 & 8 & 10 & $1: 4$ \\
Herrera (1847) & 6 & 23 & 29 & $1: 3.8$ \\
Evans (1848) & 23 & 64 & 87 & $1: 2.8$ \\
Cotte (1787) & 4 & 9 & 13 & $1: 2.3$ \\
Redfield (1831-1843) & 29 & 51 & 80 & $1: 1.7$ \\
Tegg's Chronology (1824) & 14 & 23 & 37 & $1: 1.7$ \\
Perrey & 8 & 14 & 22 & $1: 1.7$ \\
Phillip's Barbados Almanac & 11 & 7 & 18 & $1: 0.6$ \\
Totals & 145 & 444 & 589 & $1: 3.1$ \\
\hline
\end{tabular}

Only sources providing ten or more reports are included. The most reliable source is at top, the least reliable at bottom. Later chroniclers frequently used earlier records when building their chronologies which allows for the propagation of errors forward through time. Poey's bibliography entries for Warden, Perrey, Tegg's Chronology, published in London in 1824 and Phillip's Barbados Almanac for 1839 are absent or incomplete and could not be located.

\section{Reliability of Early Hurricane Compilers}

Table II lists the sources cited by Poey in his compilation and the number of storms they included in their accounts that were accepted and rejected based on the new chronology produced by the author. A ratio of rejected to accepted storms is included. Of the 15 sources that provided ten or more separate storms, an average ratio of rejected to accepted storms was 1:3.1. The most prolific source (and user of previous accounts) Schomburgk (1848) had 106 entries, 20 of which were rejected, and 86 accepted. His ratio of 1:4.3 is better than average. Edwards (1805) is the most accurate source, with a 1:17 ratio, while four sources (Redfield, Perrey, Tegg, and the Barbados Almanac) have ratios of 1:2 or worse.

That Redfield should be among the least reliable sources is a surprise. When consideration is made for his research purposes, which involved gathering large amounts of data for all types of storms, both tropical and non-tropical, then the error rate is understandable. Redfield was trying to determine the nature of storms, and being the father of this type of research considerable allowance must be accounted 
for. In addition, Poey chose from the records he was provided by Redfield, which may also skew the numbers.

The records produced by Bryan (1805), Warden (1819), Morreau de Jonnès (1822) and Southey (1827) are the most reliable. Apparently, other compilers consulted them. They include Schomburgk (1848), Evans (1848) and Johnston (1855). Johnston apparently borrowed from Schomburgk, as the original edition of his physical atlas included 50 hurricanes through 1837, but the 1855 edition included 127 hurricanes (Poey, 1855), the exact same number included in Schomburgk's 1848 book. In many instances, the authors do not mention the works they consulted, so it is difficult to determine the source document(s) consulted by the original author.

\section{Results}

\subsection{POEY RECORD}

Of the 348 individual entries for the years 1700-1855 in the original Poey record (Table I), 198 were accepted and 149 were rejected. Of the 198 entries, a total of 170 unique tropical cyclones were derived, since some entries were for locations affected by the same storm. Of the 149 rejected entries, 131 were unique rejected entries, the excess being due to garbled dating of years, and multiple entries of bad data for the supposed same storm. So, the original Poey list of 348 storms (1700-1855) actually consisted of only 271 separate storm/non-storm events.

Of the 170 accepted tropical cyclones, 13 were undated in Poey and are now dated. The entire 156-year period has an average of just over one tropical cyclone per year, or about $10 \%$ of the probable average for the period (assuming modern Atlantic basin seasonal totals of 10 tropical cyclones (Pasch et al., 2004) was also true at this time).

\subsection{MILLAS RECORD}

Until the work of Millás (1968), the sources used by Poey were not critically examined. So, for more than a century many of these errors continued to be carried forward by historians of the region and meteorologists without much investigation to its accuracy. The original list of Poey was culled of its obvious non-tropical origin storms and several of the storms correctly assumed to be part of the same system by Tannehill and his predecessors. As mentioned earlier, the Tannehill (1938) record continues to be used as a reference in most hurricane compilations to this day. Millás makes frequent reference to Tannehill.

Millás (1968) modified the Poey record, even though he also uncritically considered Tannehill, Poey and other compilers as equal authorities. The strength of Millás's work was his re-reading of as many of the secondary sources listed in Poey 
(1855) as he could find, including those in non-English languages. He also emphasized the calendar differences in the sources he consulted and corrected many long-standing dates. His reliance on these secondary sources was also a major limitation to his efforts as the analysis of primary documents now reveals.

Since Millás made adjustments to the pre-1801 portion of the Poey record, it is of importance to document his adjustments for the years 1700-1800. Twelve storms accepted by Millás (1968), and not included in Poey (1855) were confirmed from independent sources but a number are undated or misdated. Other storms accepted by Millás were rejected outright or the date so garbled (even though the source was valid) as to be useless. Some of these dating and location errors for 1750-1786 are documented in Chenoweth (2003). Table III lists the accepted and rejected Millás storms. The new assessment of his record is that 85 storms from 1700-1800 are accepted with 12 not previously known. Ten of the 85 storms were undated or misdated, limiting their usefulness for climatologists. Between Poey and Millás, a total of 100 unique storms were recorded, with 16 undated prior to this study and only one now remaining undated.

\subsection{OTHER WORKS AND A ACOMPREHENSIVE" CHRONOLOGY}

Many storms that pass through the Caribbean eventually make landfall somewhere within the borders of the United States. Tropical systems documented by Ludlum (1963) were also linked with the new chronology of Caribbean storms and appear in a separate column in Table IV. A number of Ludlum's storms are undated but new evidence helps to date the storms exactly, or to narrow the date range down to a narrow range of likely dates.

Since 1982, a number of researchers have gathered new information on previously unknown tropical cyclones. Teachout (1982) identified six new storms affecting Bermuda in the 1710s and 1720s. Rappaport and Fernandez-Partagás (1995) identified a number of new storms in both primary and secondary literature. Fernandez-Partagás and Diaz (1995a) cover the final years of the Poey list and added previously unidentified tropical cyclones. Table IV includes only those storms included in HURDAT that were known prior to the work of FernandezPartagás. For this reason, readers interested in a complete list of Atlantic tropical cyclones need to consult the HURDAT record as will as Table IV. One new storm in Jamaica and the merging of two HURDAT systems are listed in Table IV and have not yet been added to HURDAT. Other researchers have also added to the record of U.S. land-falling tropical cyclones (e.g. Sandrik and Landsea, 2003; Mock, 2004).

Two additional columns in Table IV include the work by Mock (2004) on South Carolina tropical cyclones. His work is based on extensive archival work on sources from South Carolina not previously studied. Garcia-Herrera et al. (2005) have published a list of tropical cyclones from Spanish archive records and include important new details on both new and previously documented storms. 
M. CHENOWETH

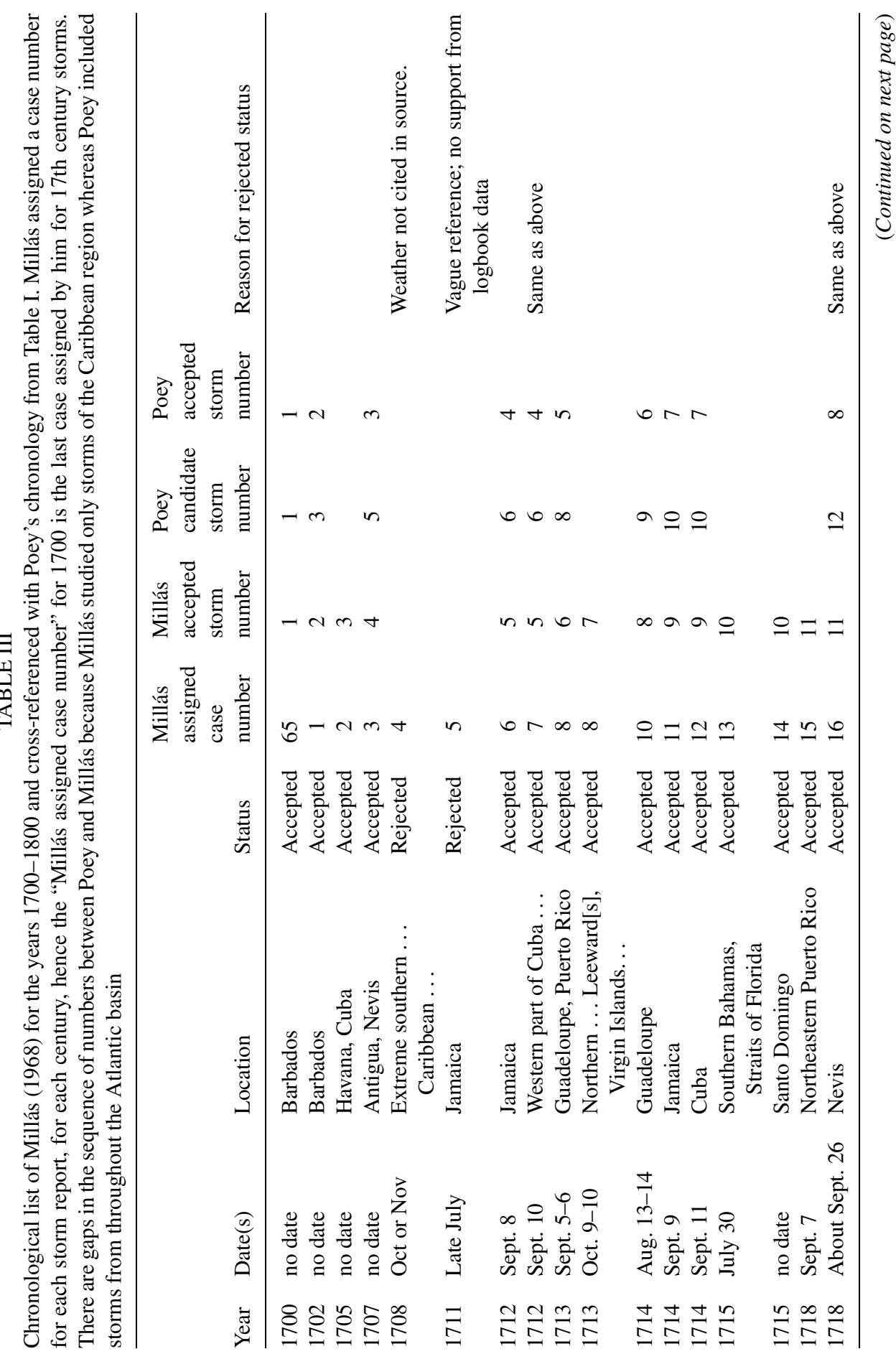


REASSESSMENT OF HISTORICAL ATLANTIC TROPICAL CYCLONES

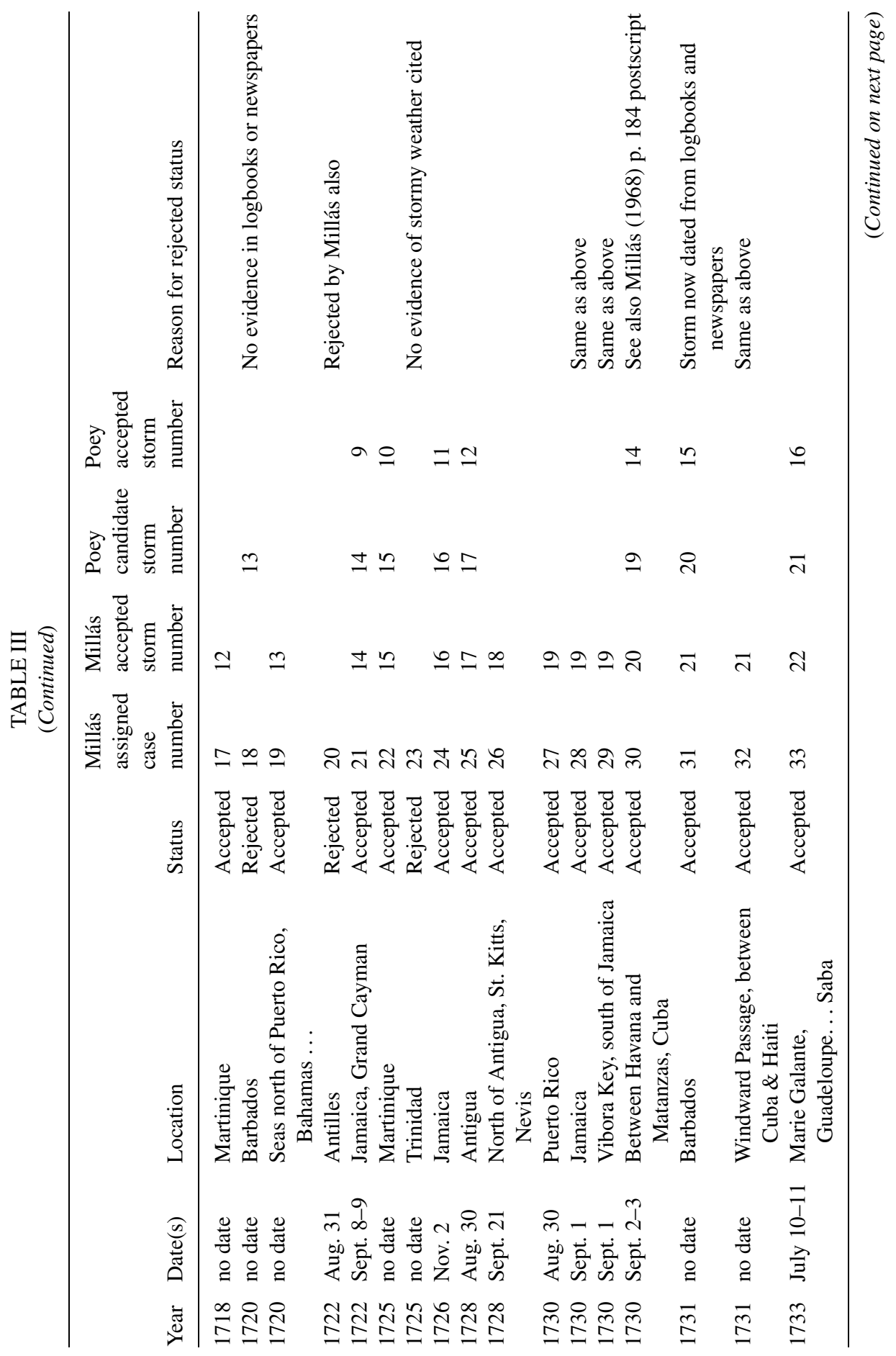


M. CHENOWETH

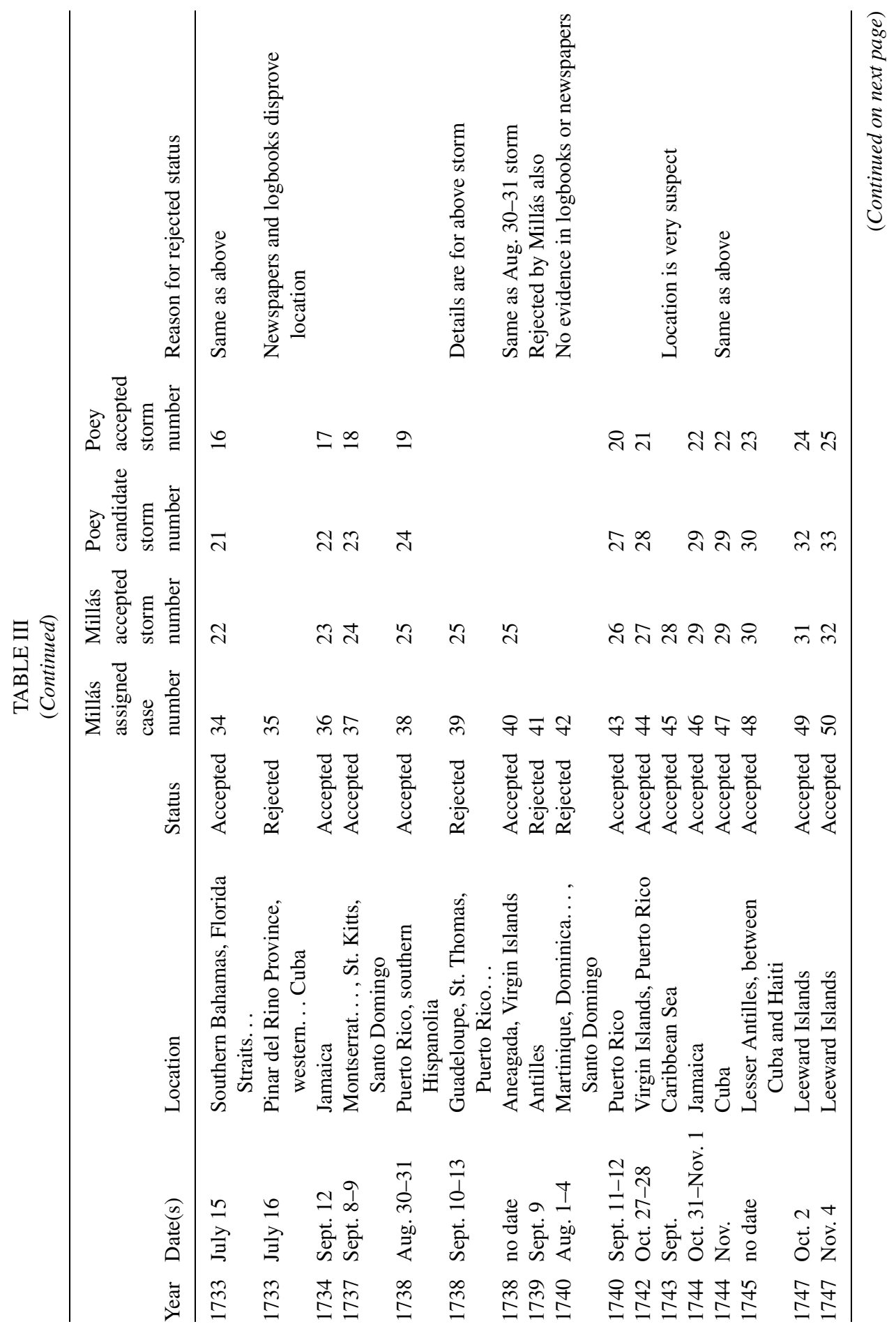


REASSESSMENT OF HISTORICAL ATLANTIC TROPICAL CYCLONES

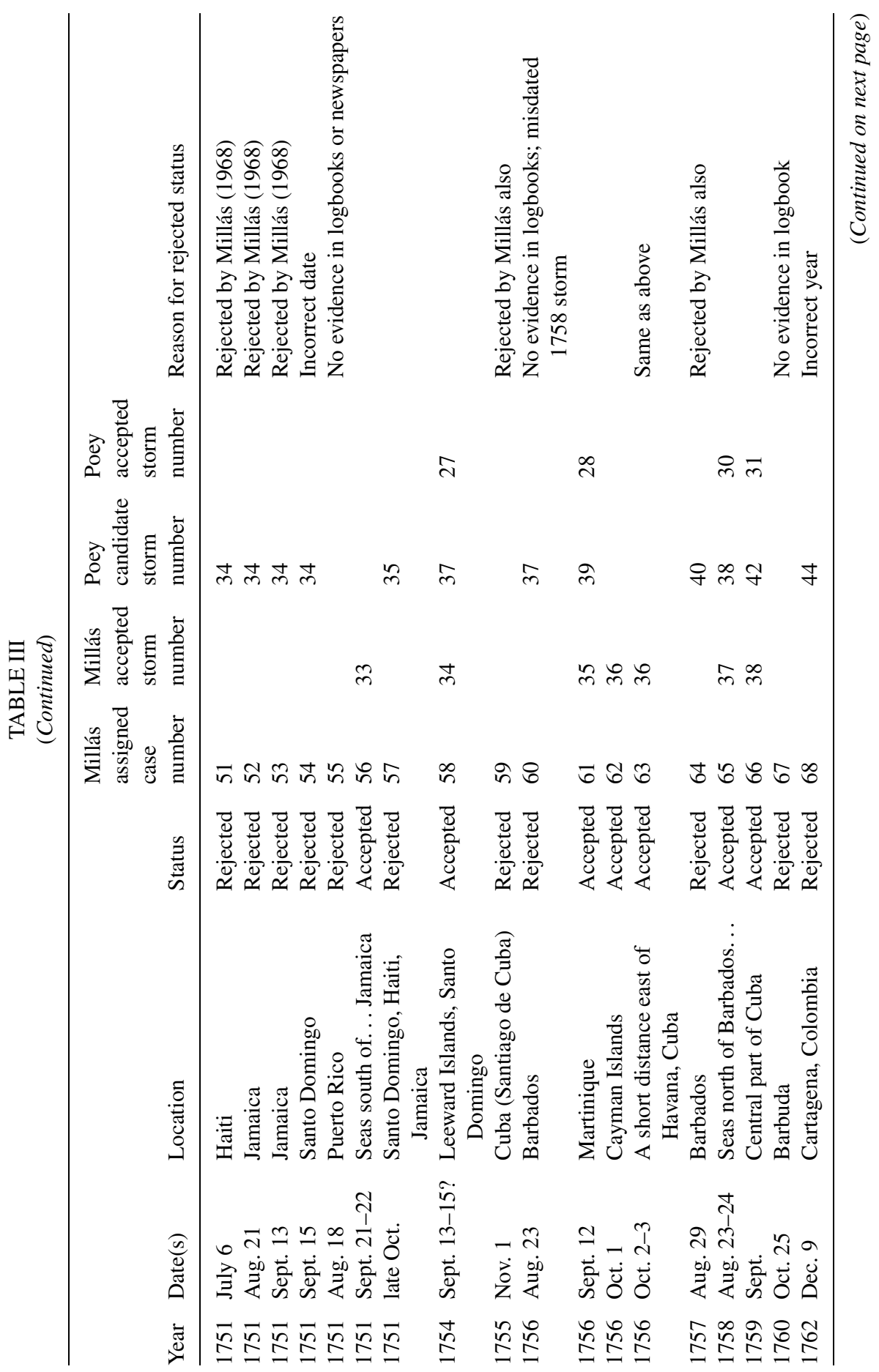


M. CHENOWETH

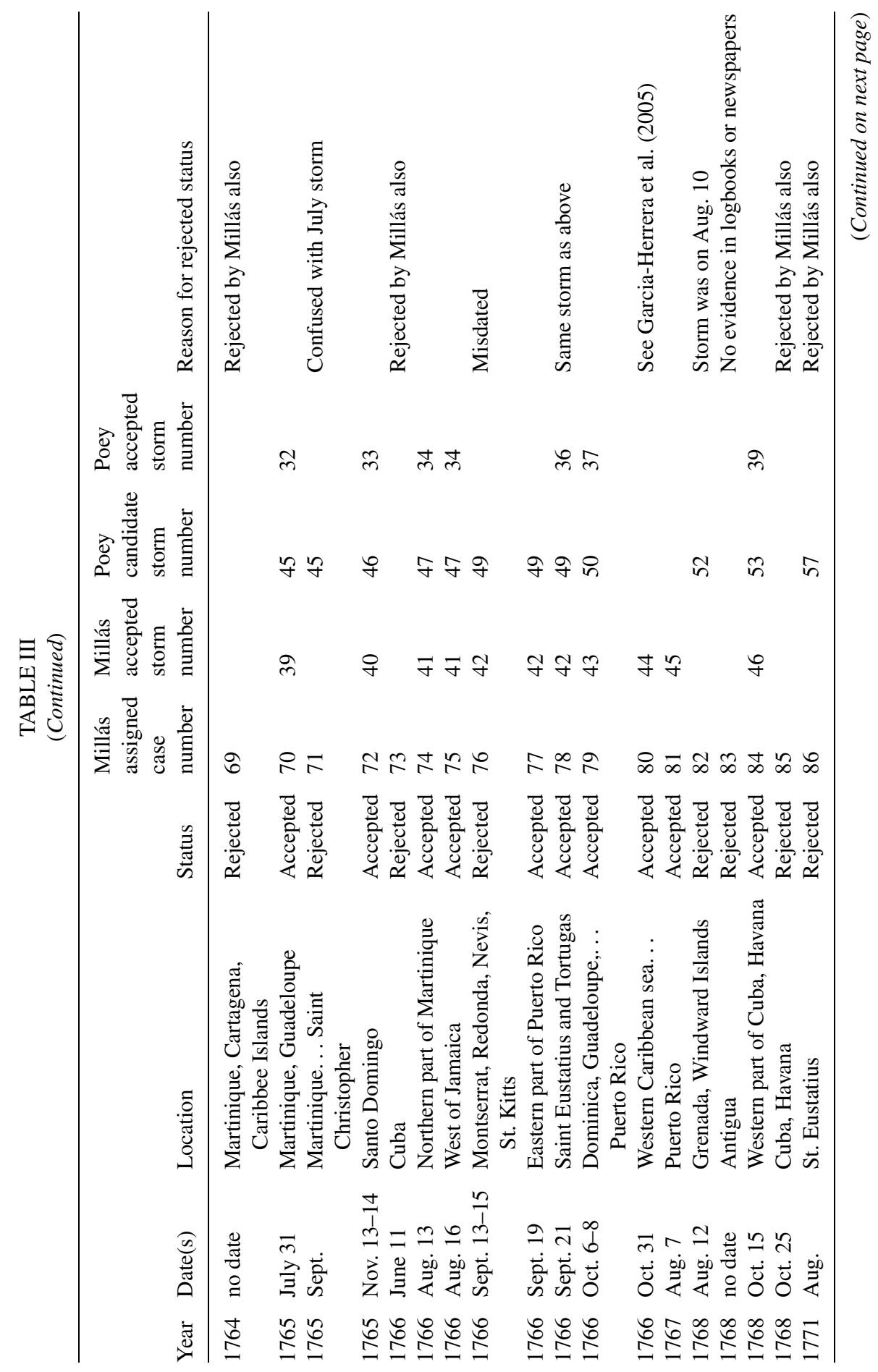


REASSESSMENT OF HISTORICAL ATLANTIC TROPICAL CYCLONES

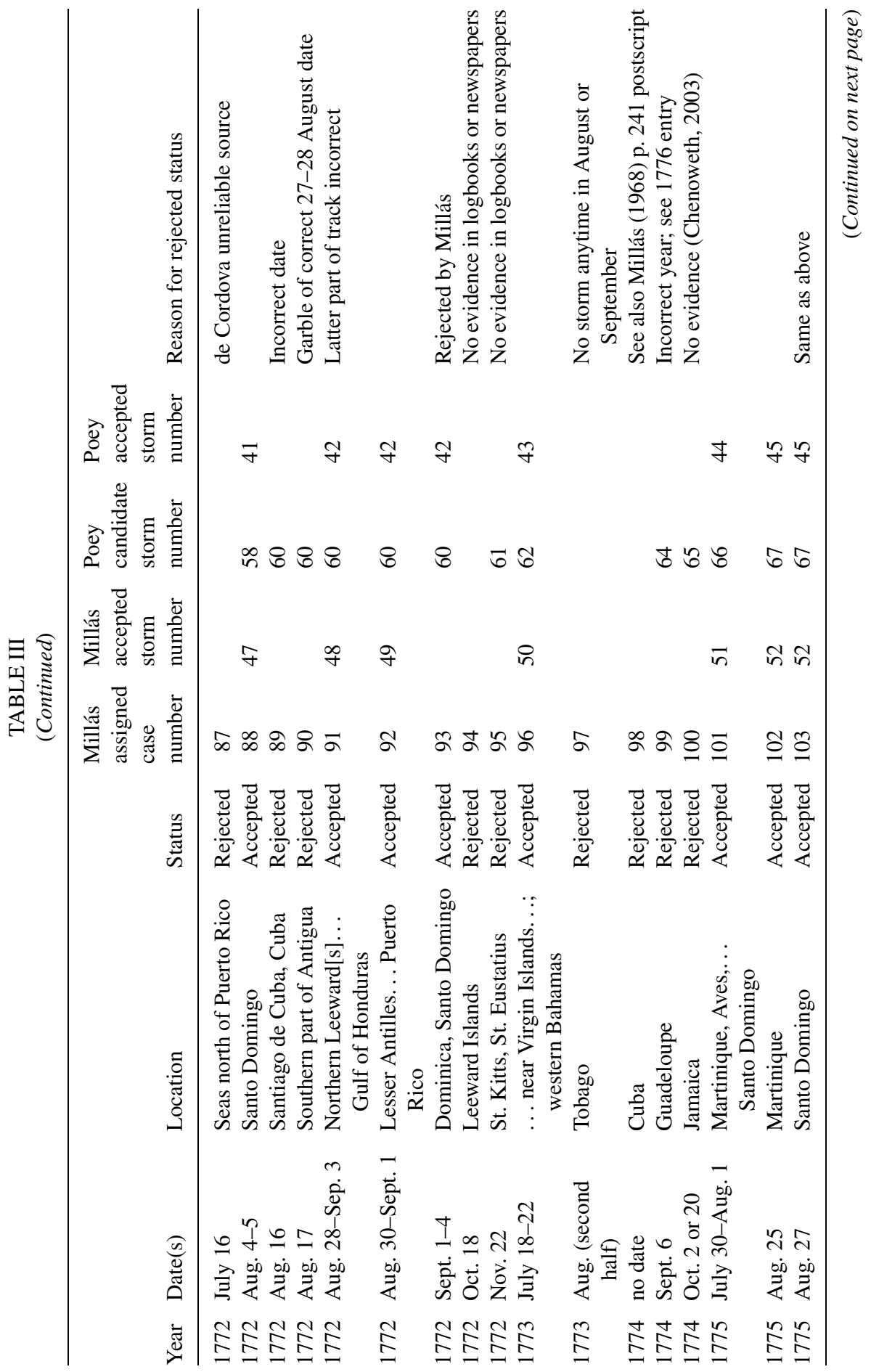


M. CHENOWETH

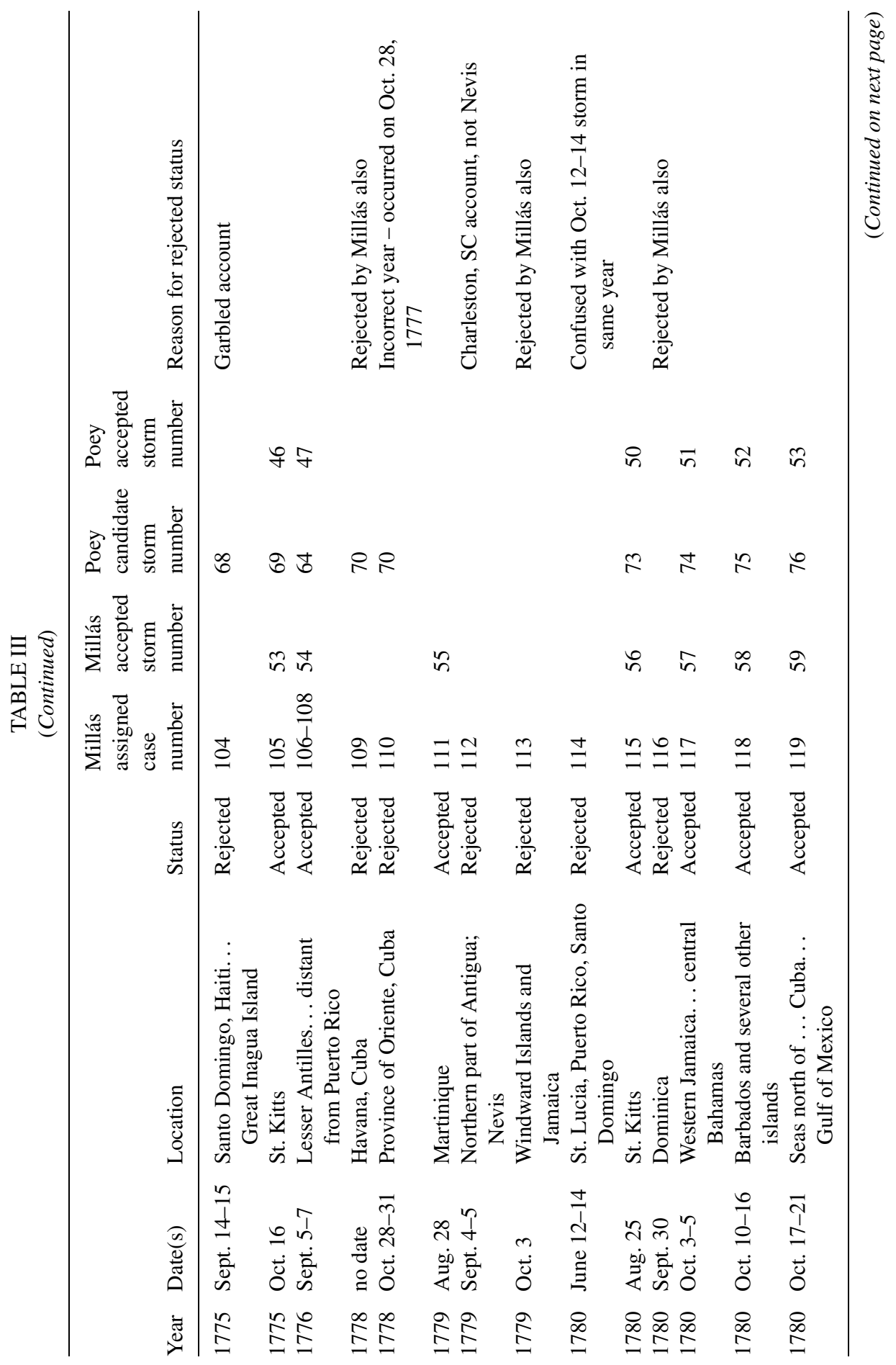


REASSESSMENT OF HISTORICAL ATLANTIC TROPICAL CYCLONES

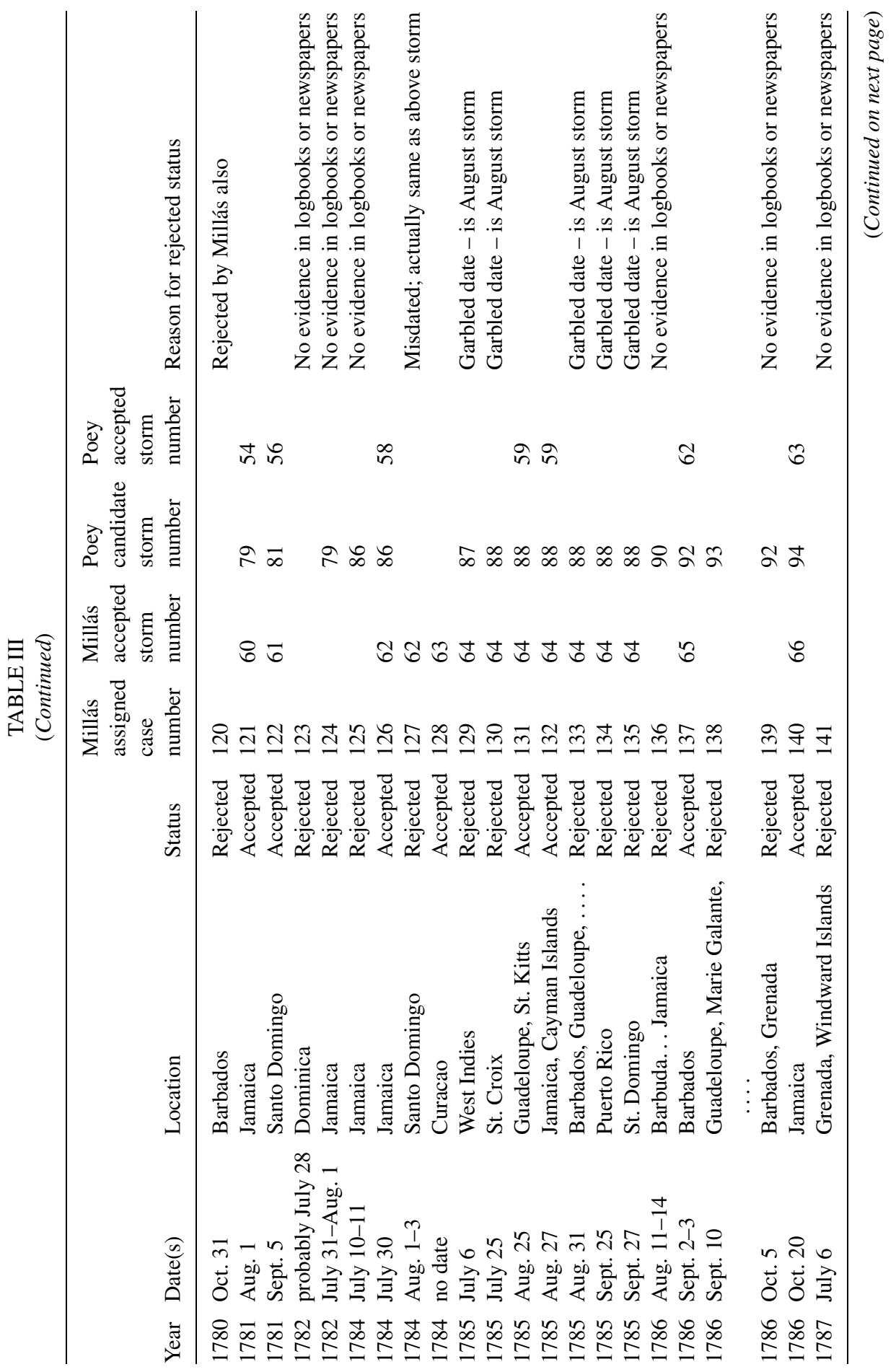




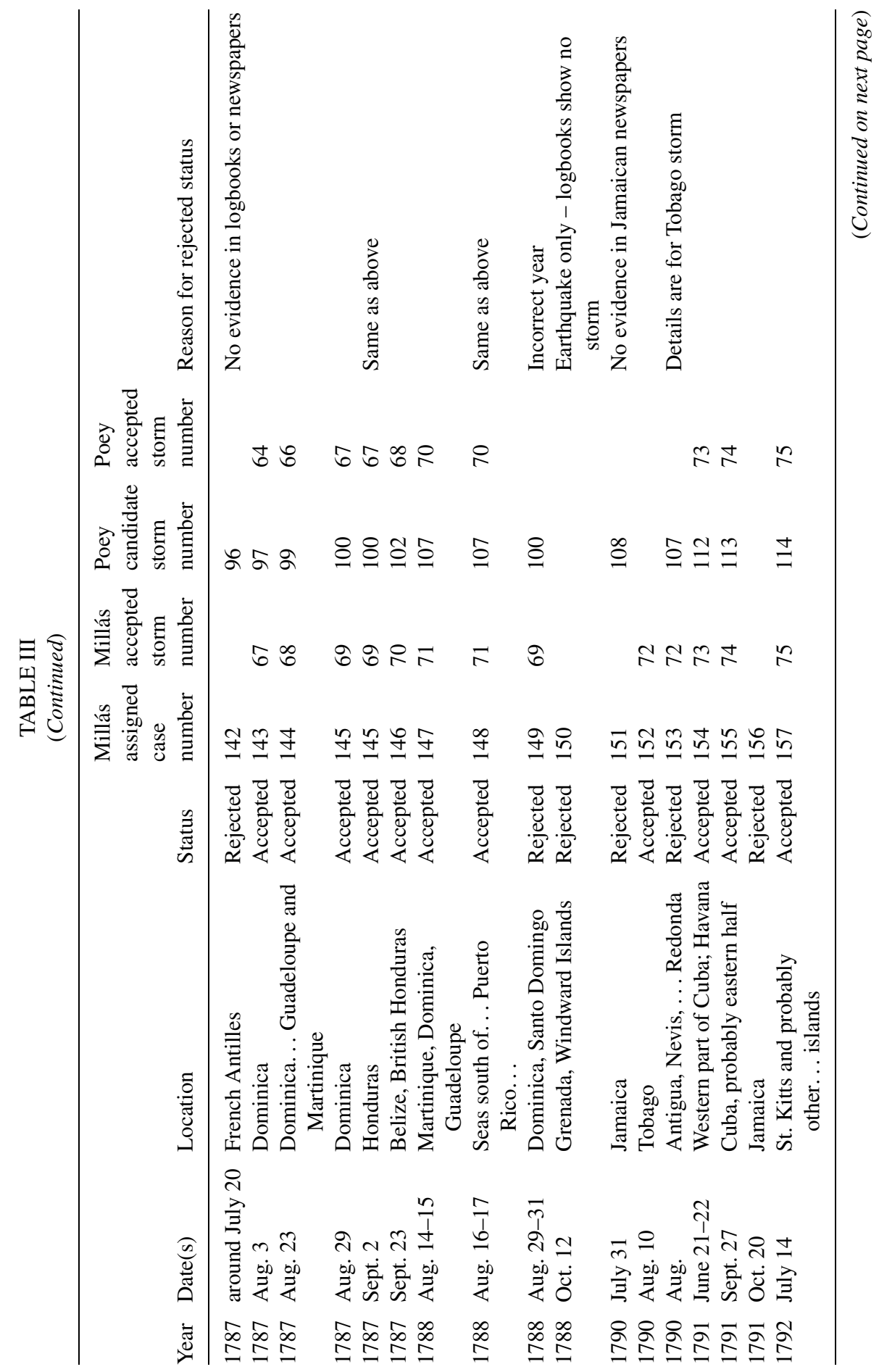


REASSESSMENT OF HISTORICAL ATLANTIC TROPICAL CYCLONES

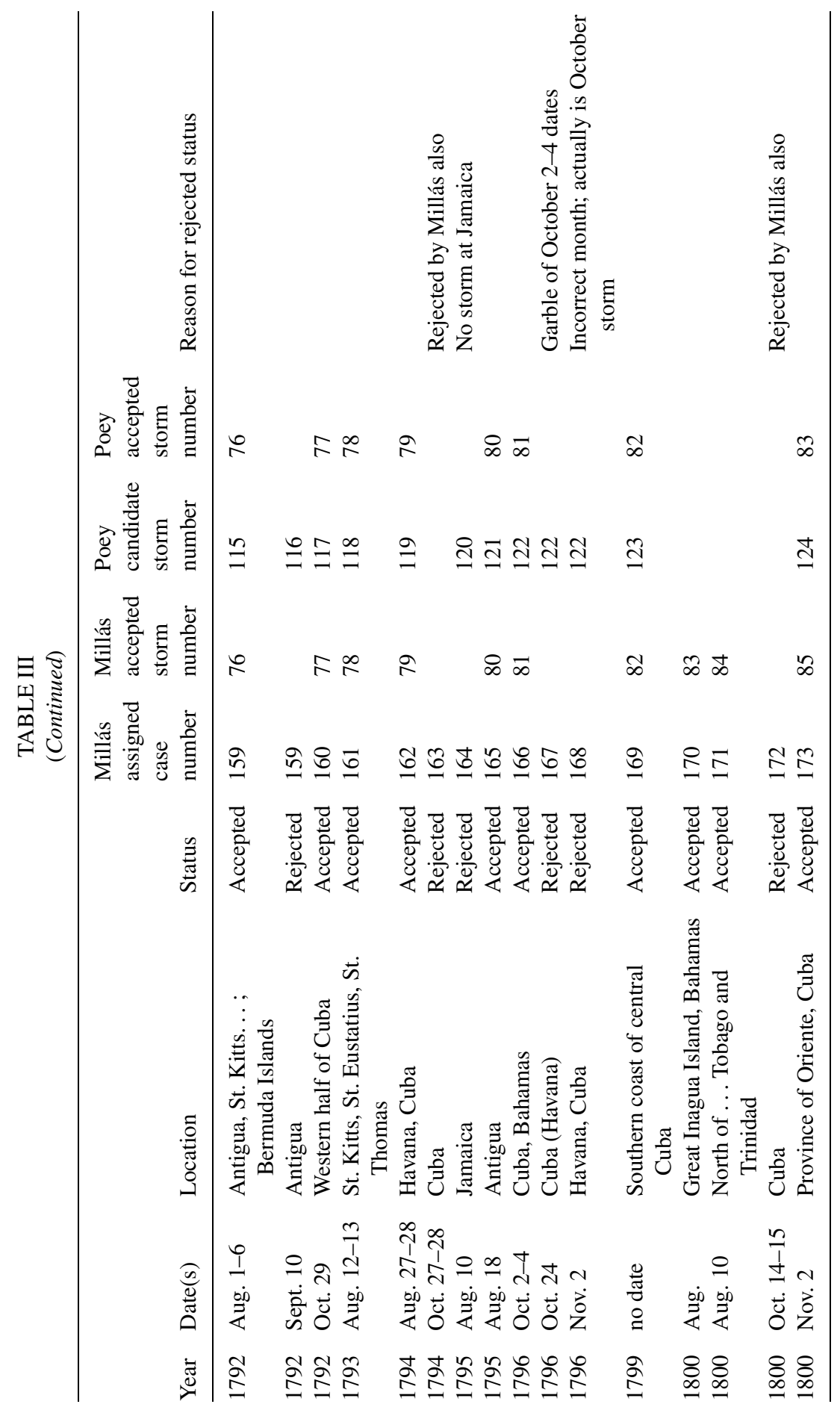


M. CHENOWETH

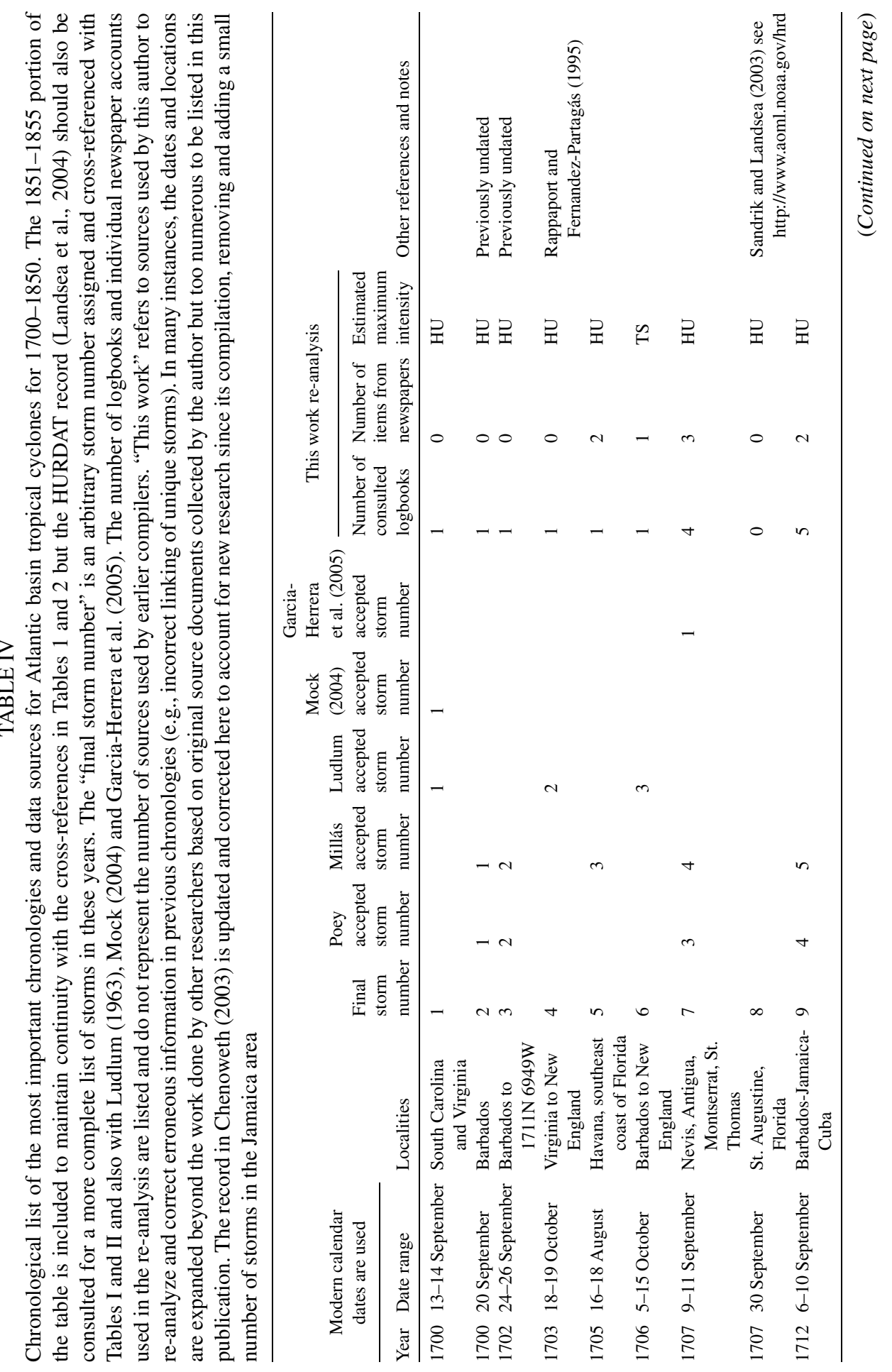


REASSESSMENT OF HISTORICAL ATLANTIC TROPICAL CYCLONES

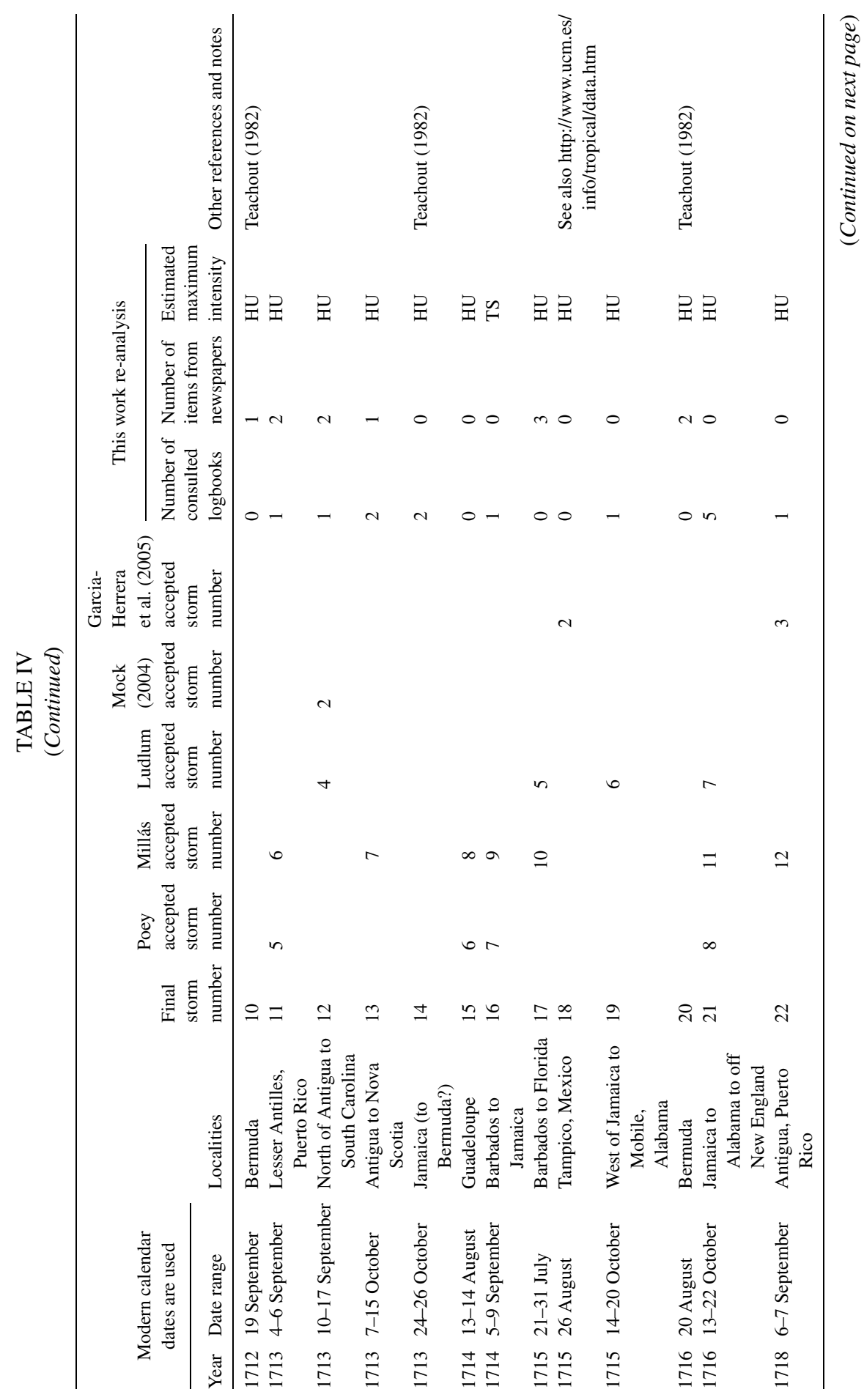


M. CHENOWETH

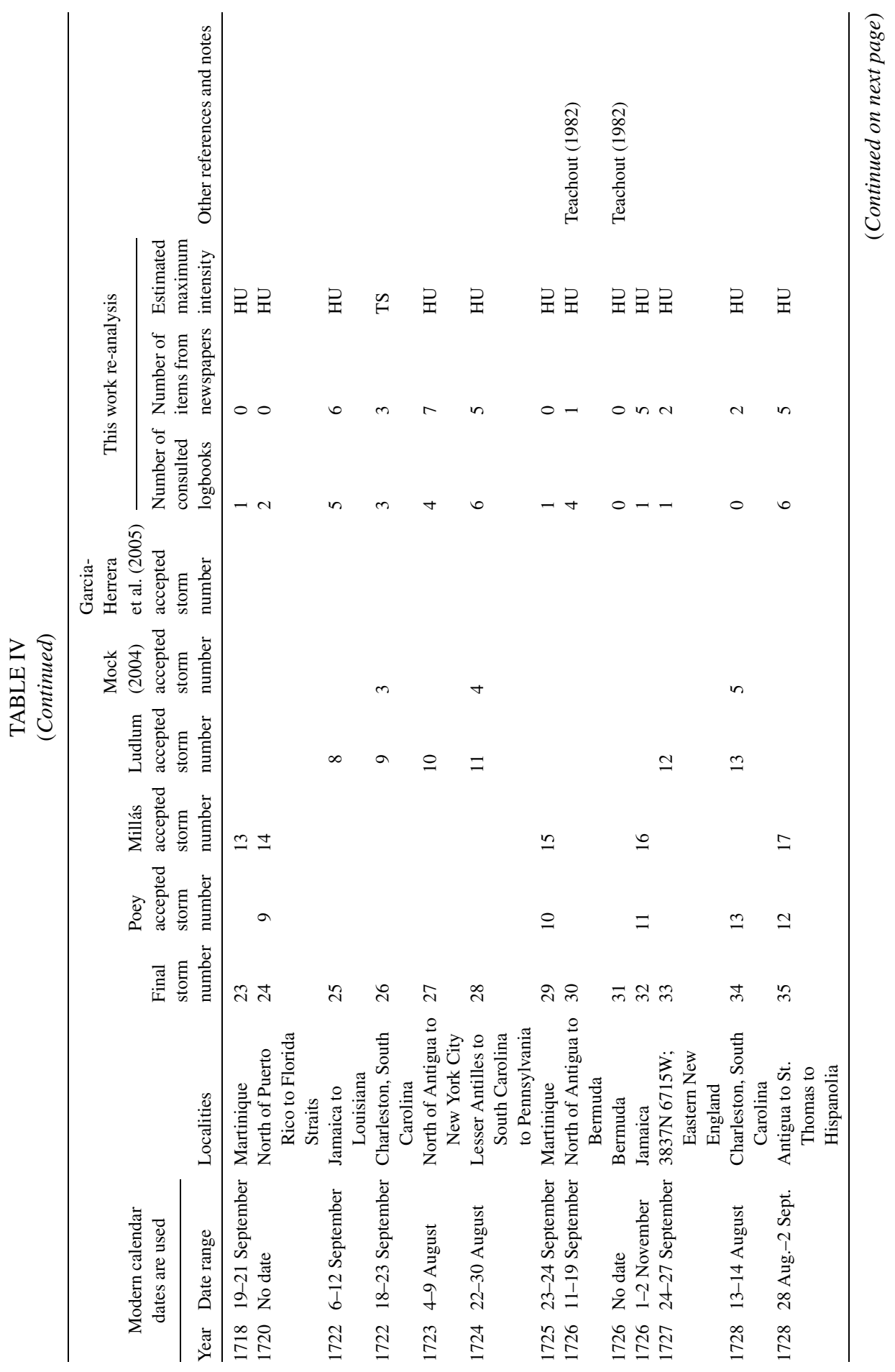


REASSESSMENT OF HISTORICAL ATLANTIC TROPICAL CYCLONES

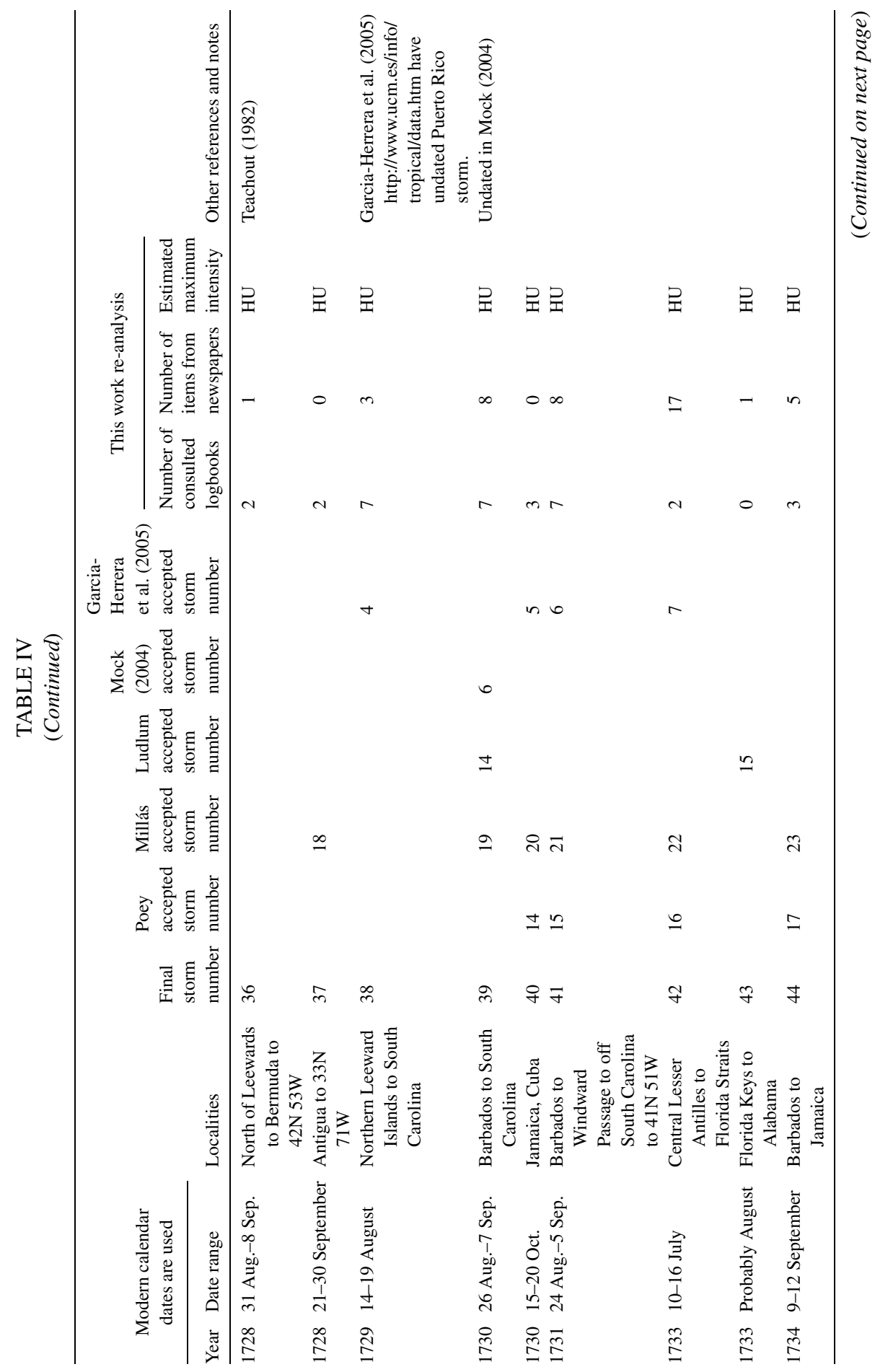


M. CHENOWETH

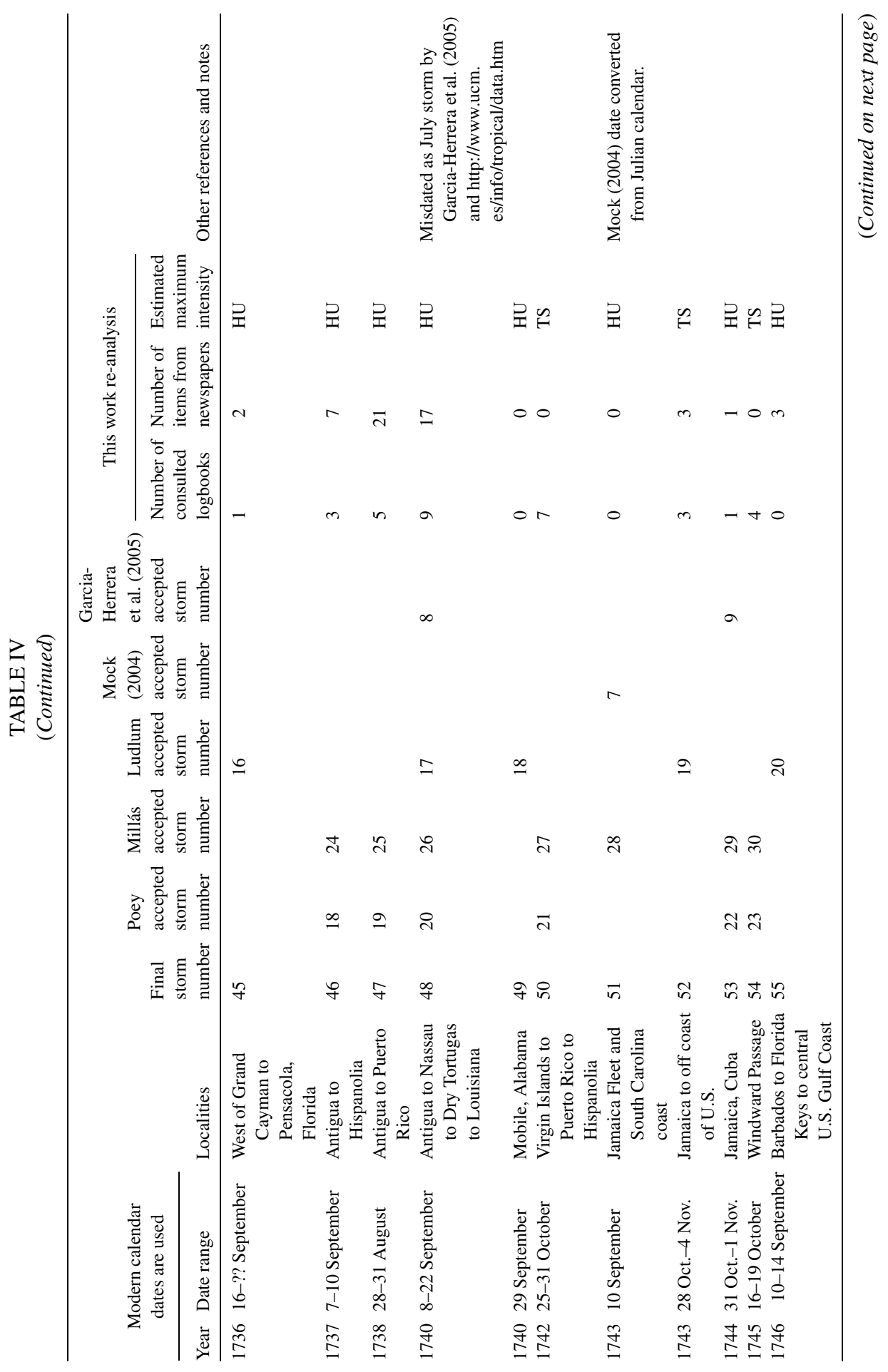


REASSESSMENT OF HISTORICAL ATLANTIC TROPICAL CYCLONES

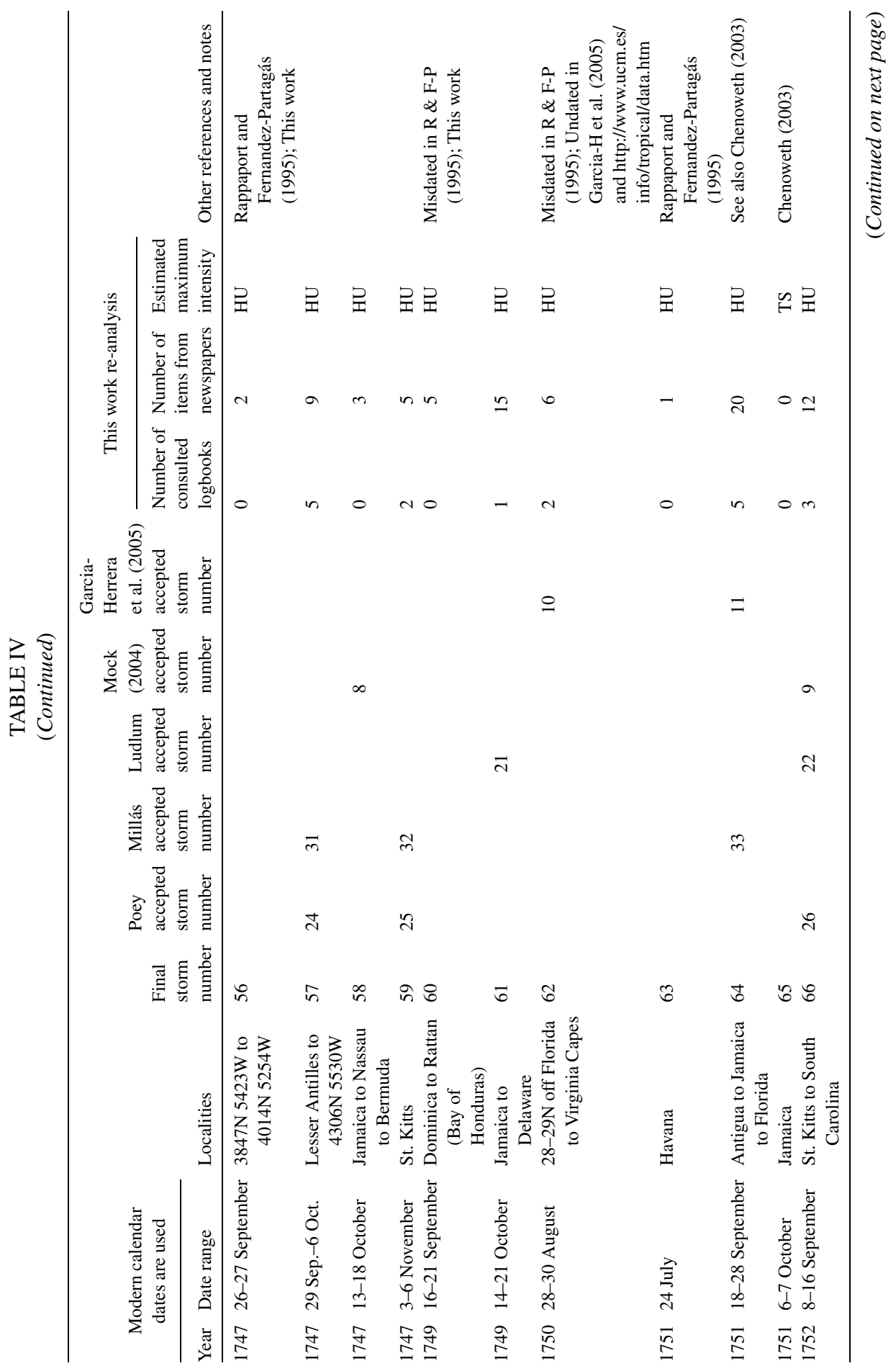


M. CHENOWETH

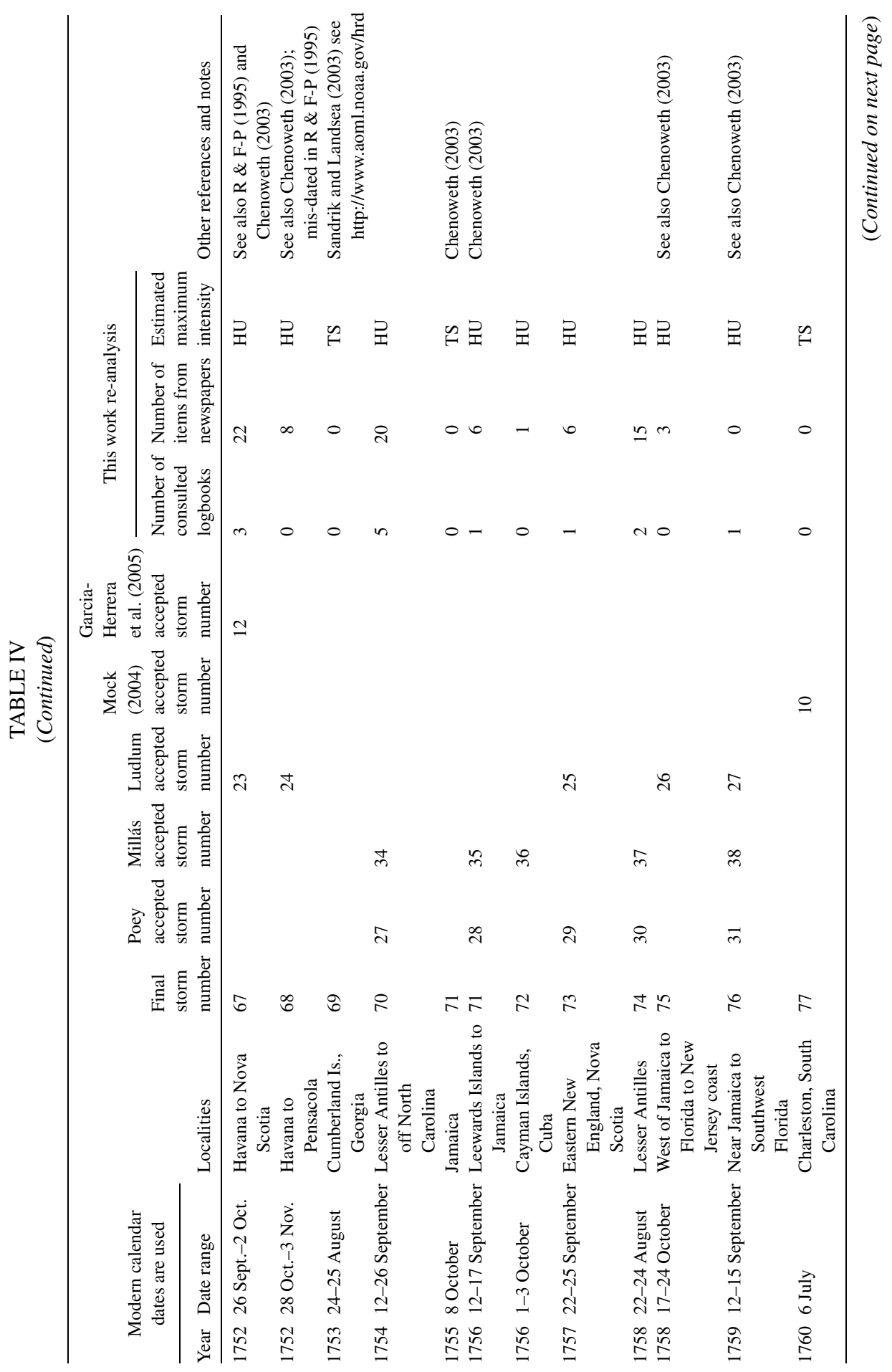


REASSESSMENT OF HISTORICAL ATLANTIC TROPICAL CYCLONES

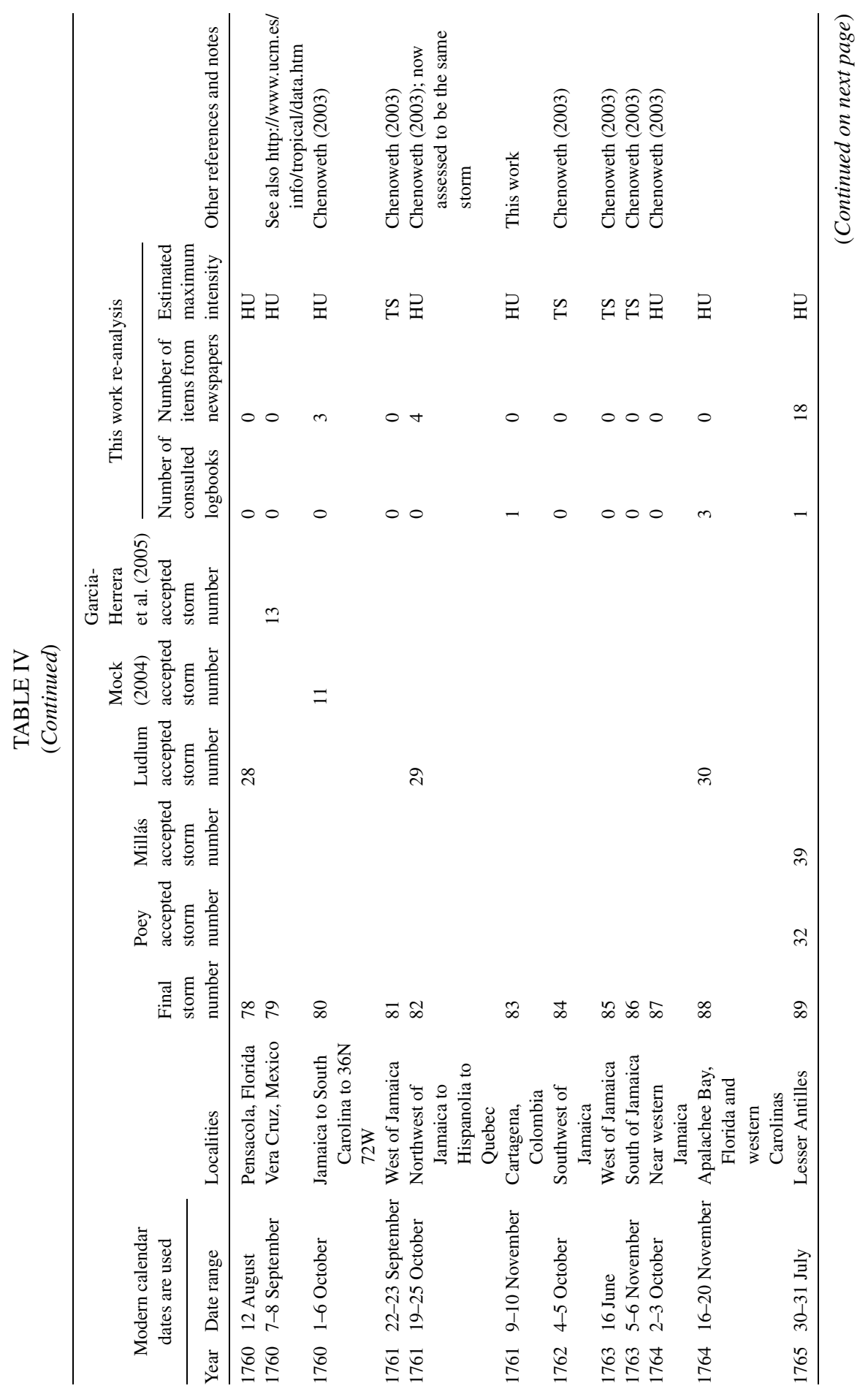


M. CHENOWETH

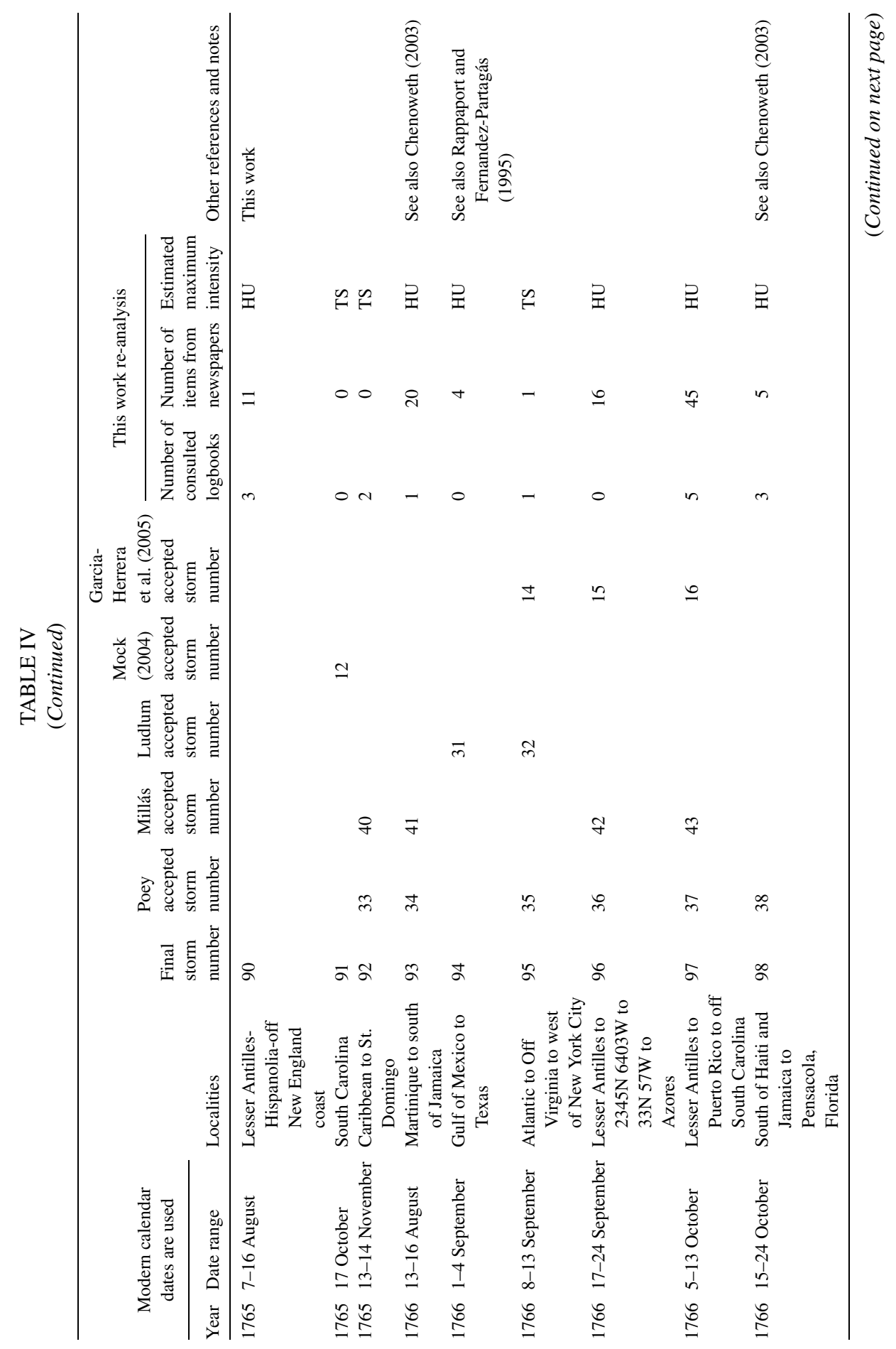


REASSESSMENT OF HISTORICAL ATLANTIC TROPICAL CYCLONES

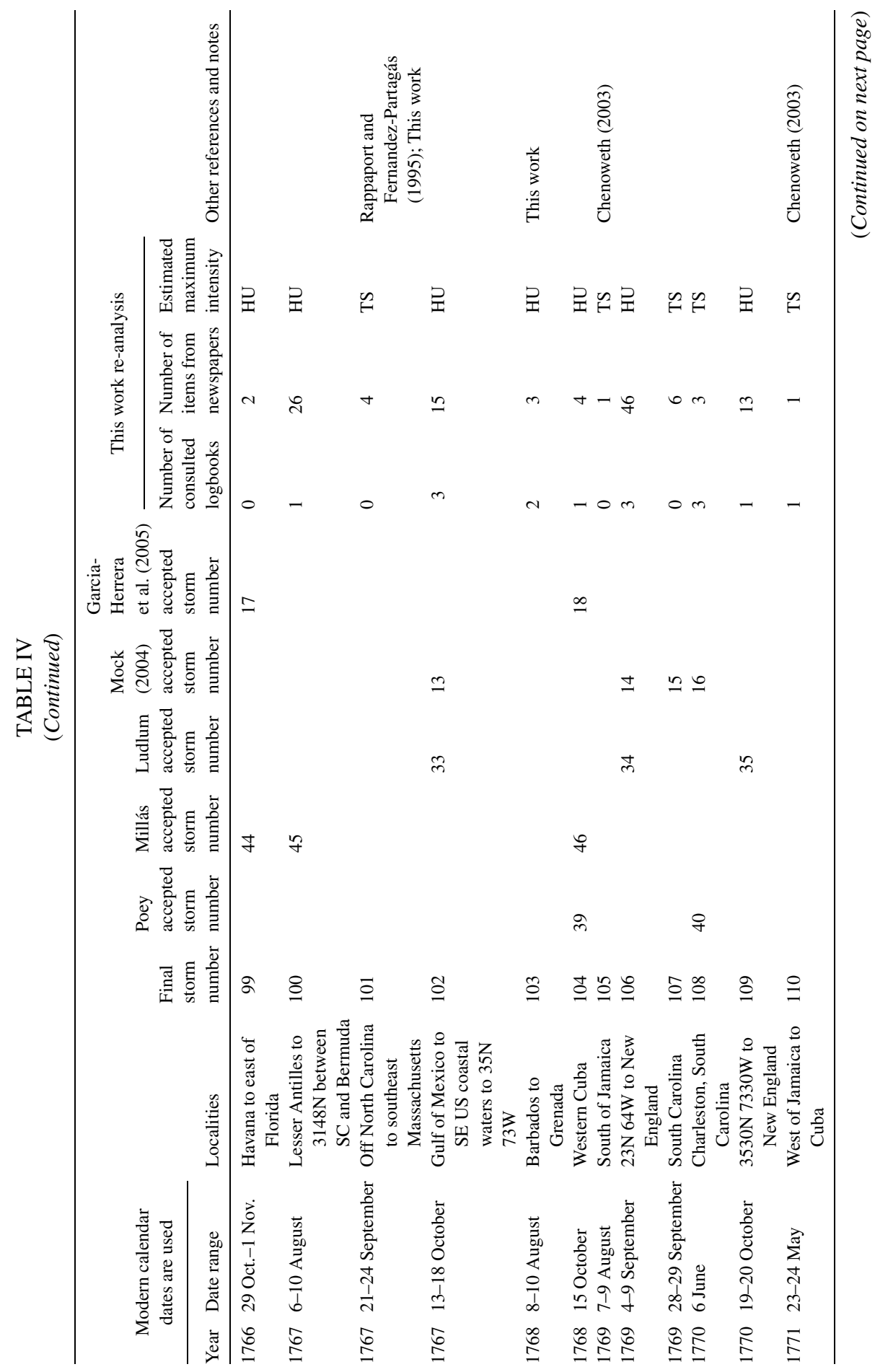


M. CHENOWETH

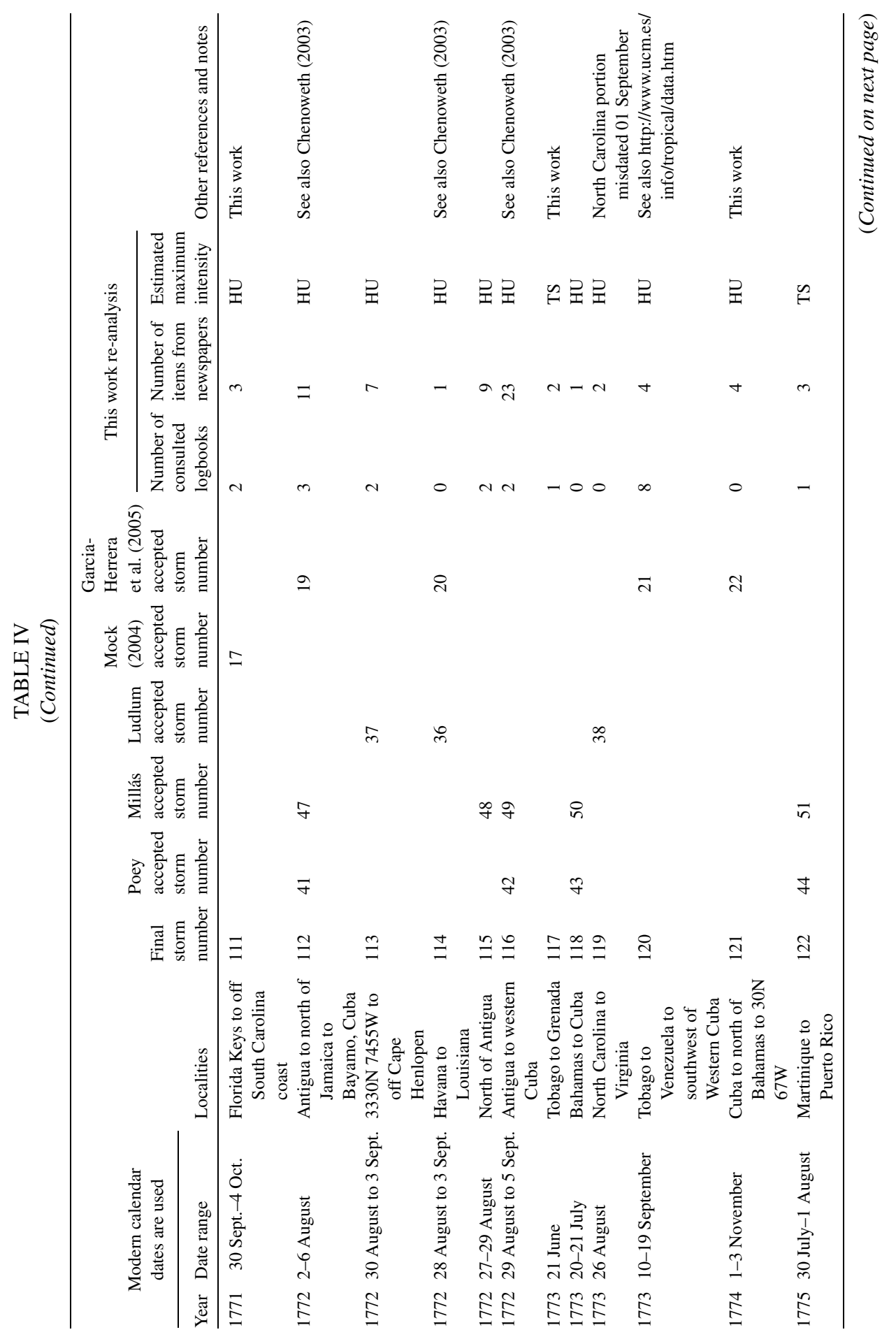


REASSESSMENT OF HISTORICAL ATLANTIC TROPICAL CYCLONES

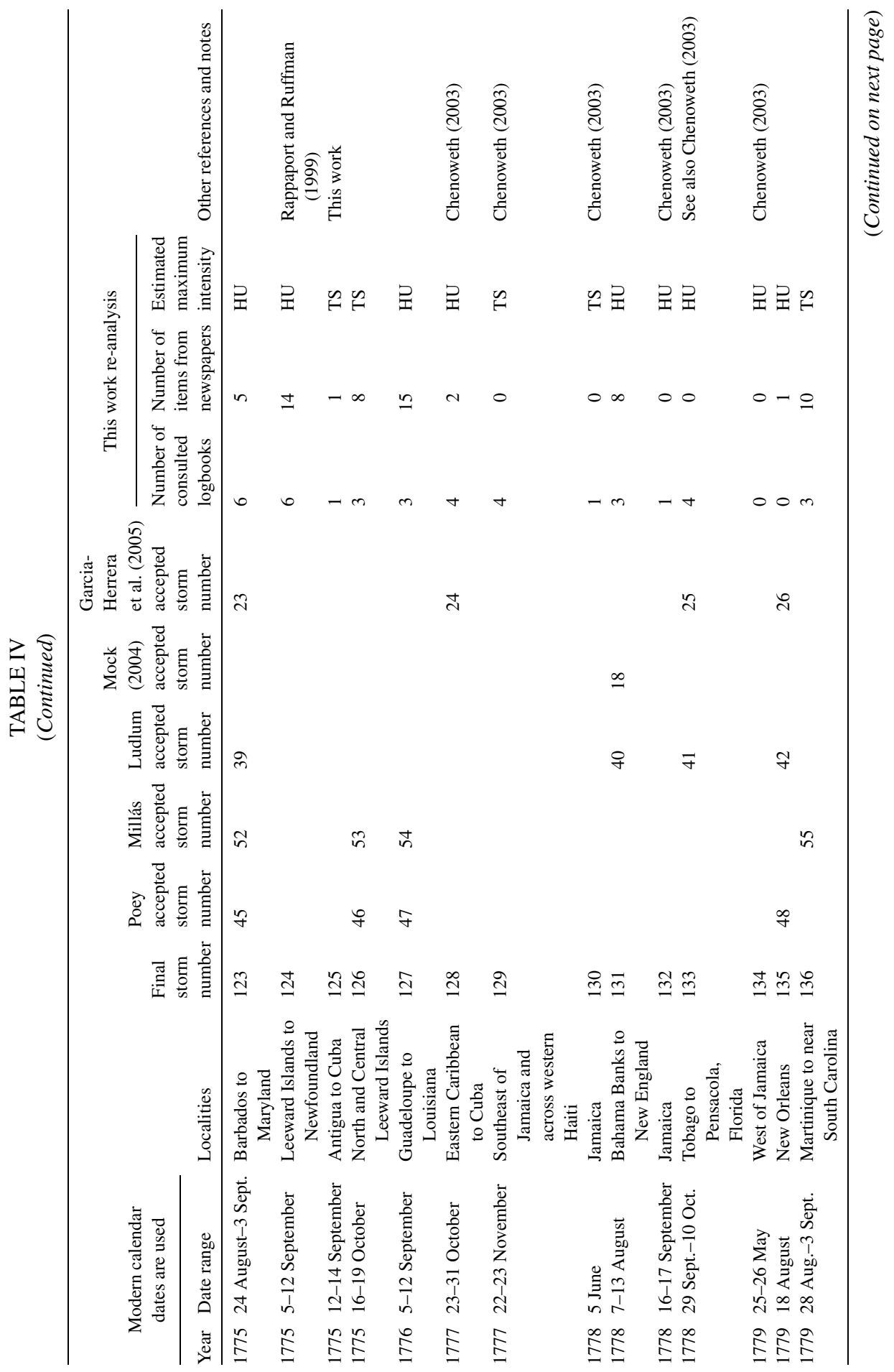


M. CHENOWETH

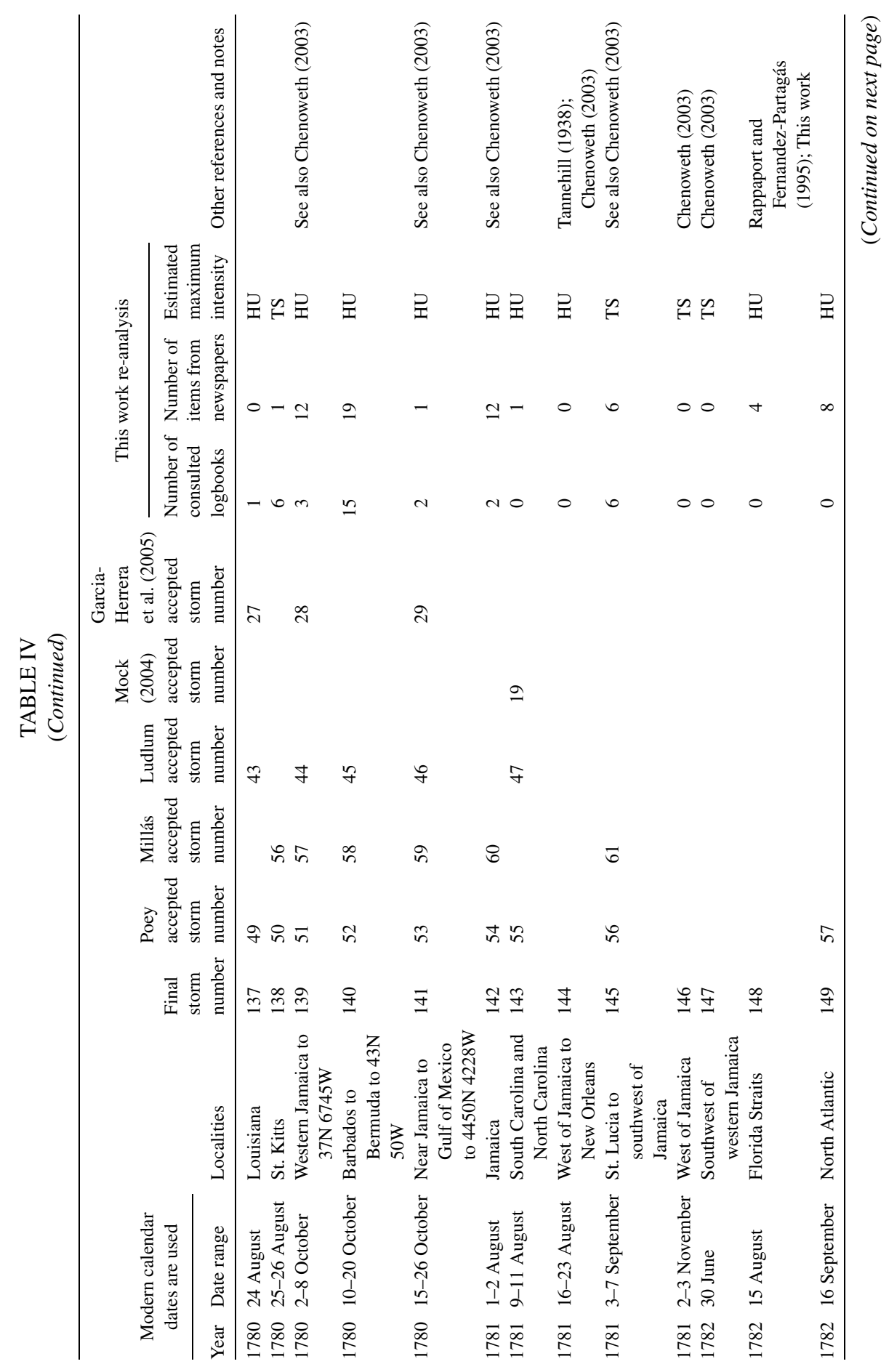


REASSESSMENT OF HISTORICAL ATLANTIC TROPICAL CYCLONES

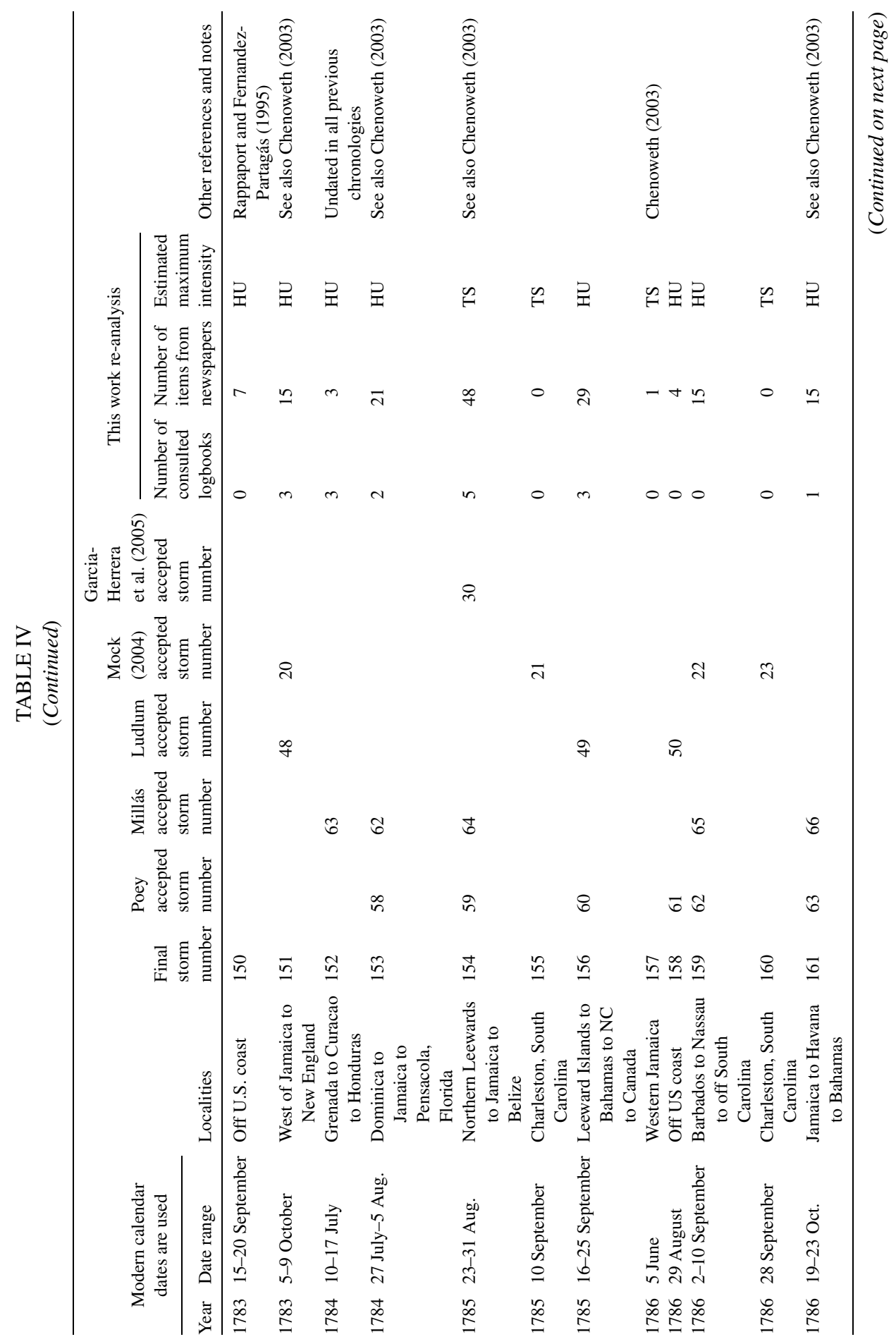


M. CHENOWETH

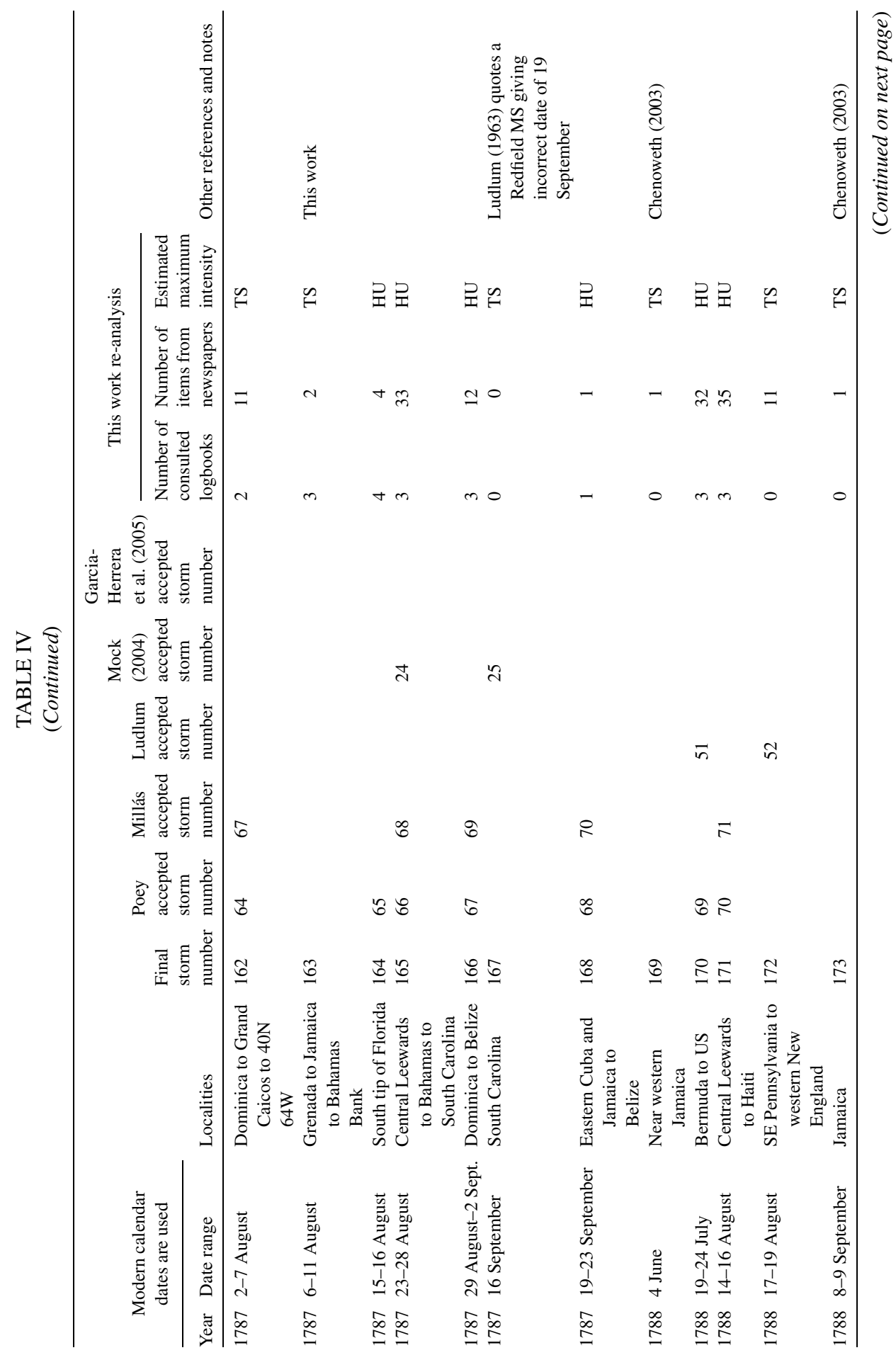


REASSESSMENT OF HISTORICAL ATLANTIC TROPICAL CYCLONES

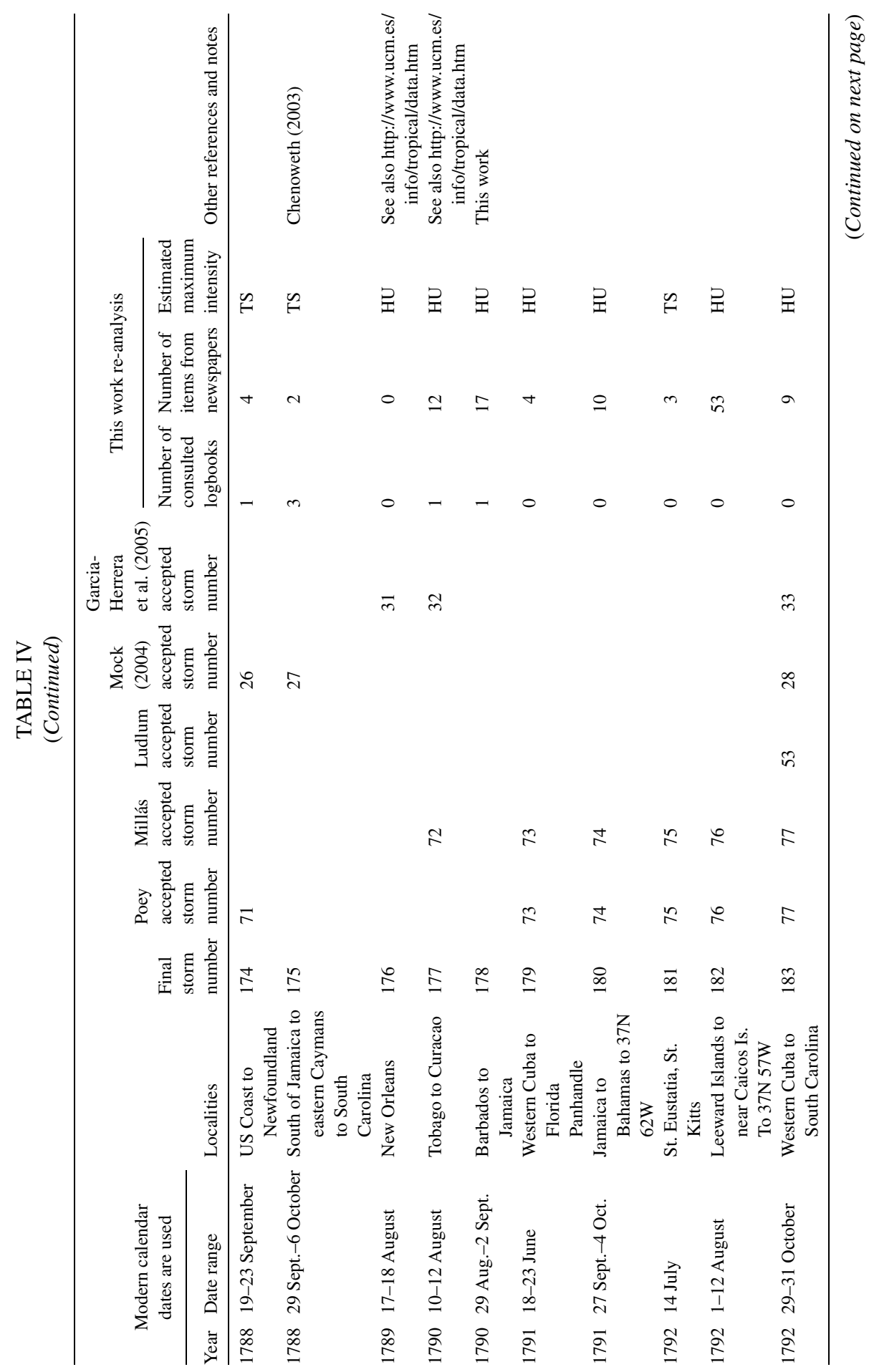


M. CHENOWETH

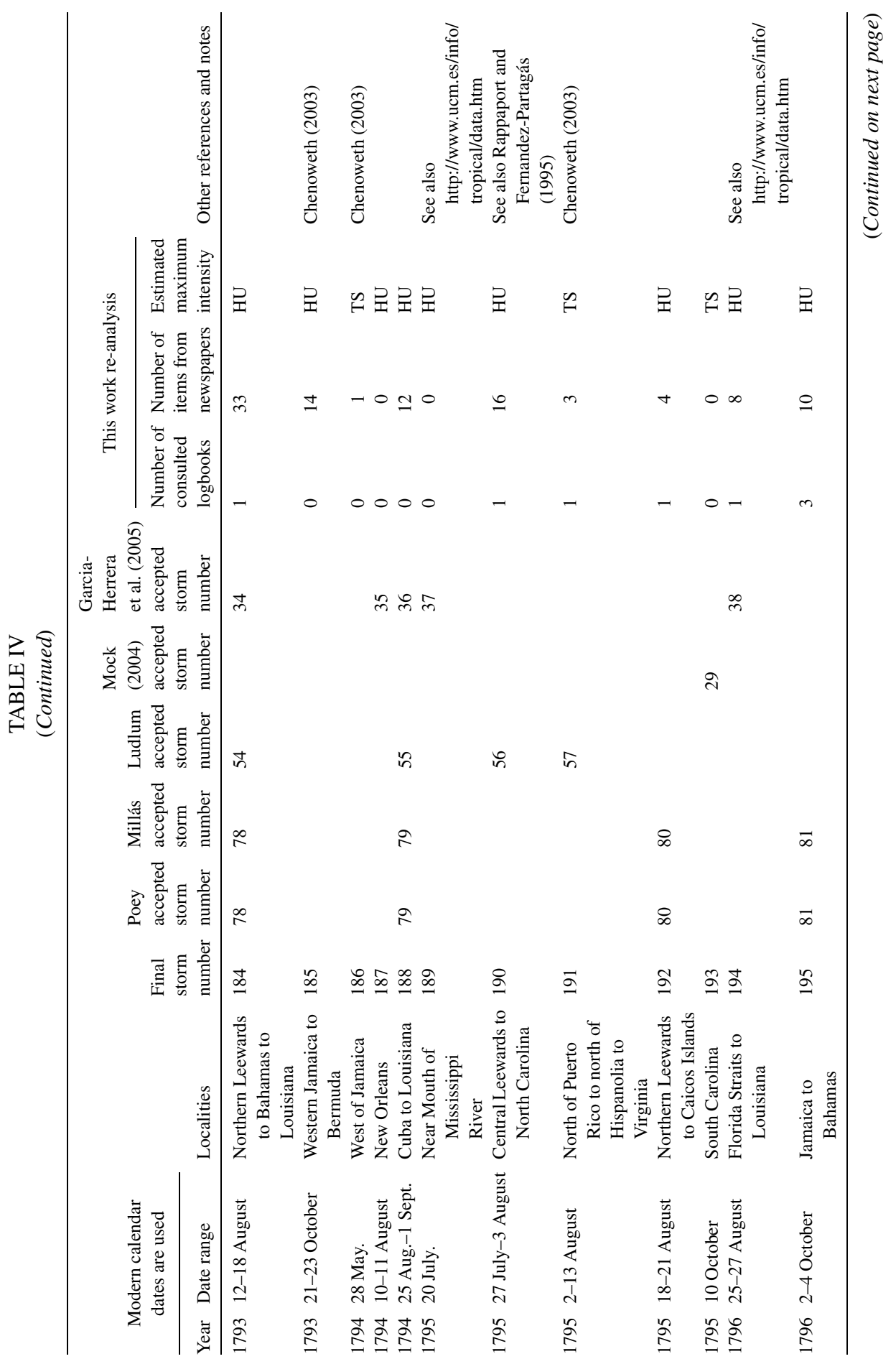


REASSESSMENT OF HISTORICAL ATLANTIC TROPICAL CYCLONES

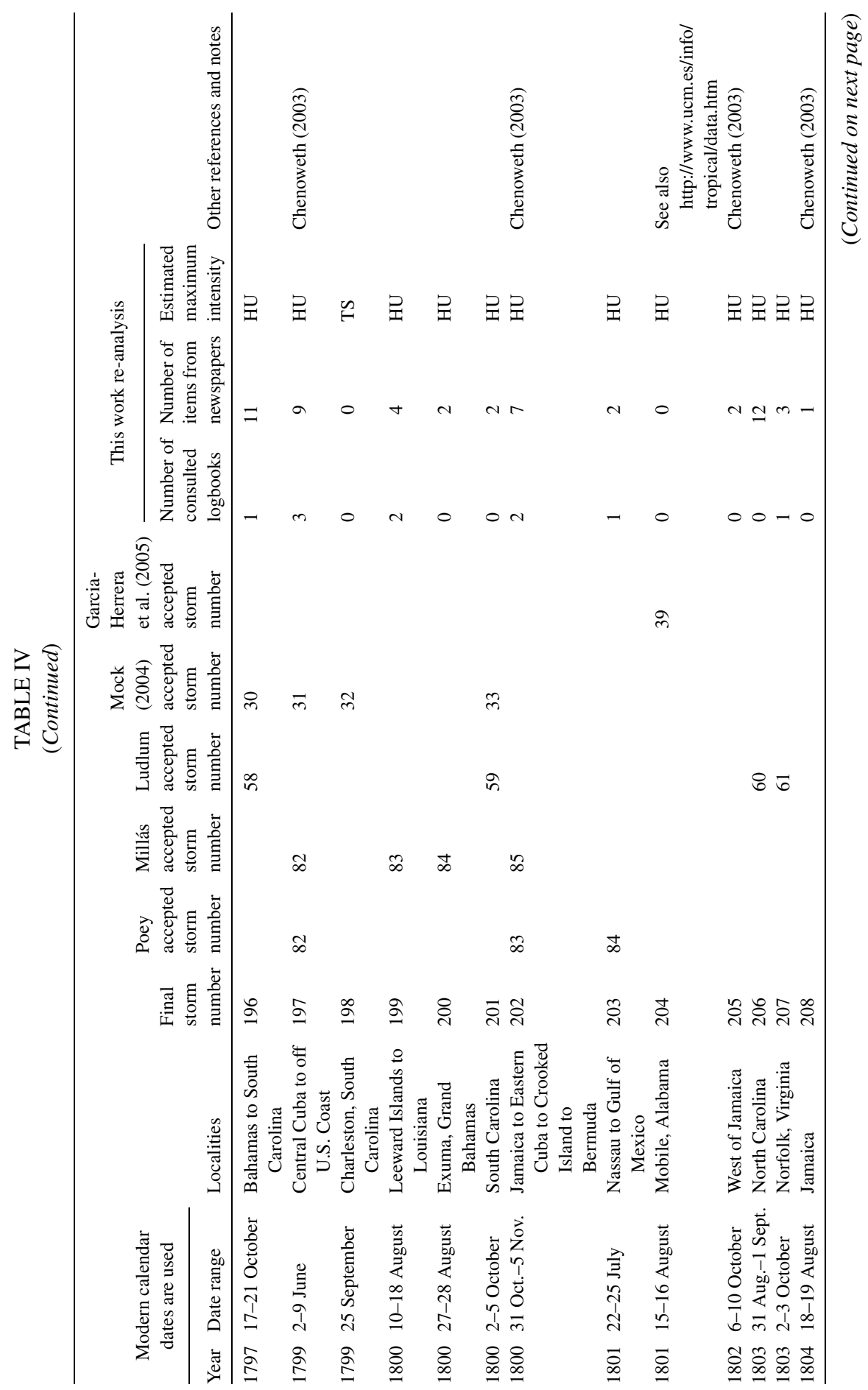


M. CHENOWETH

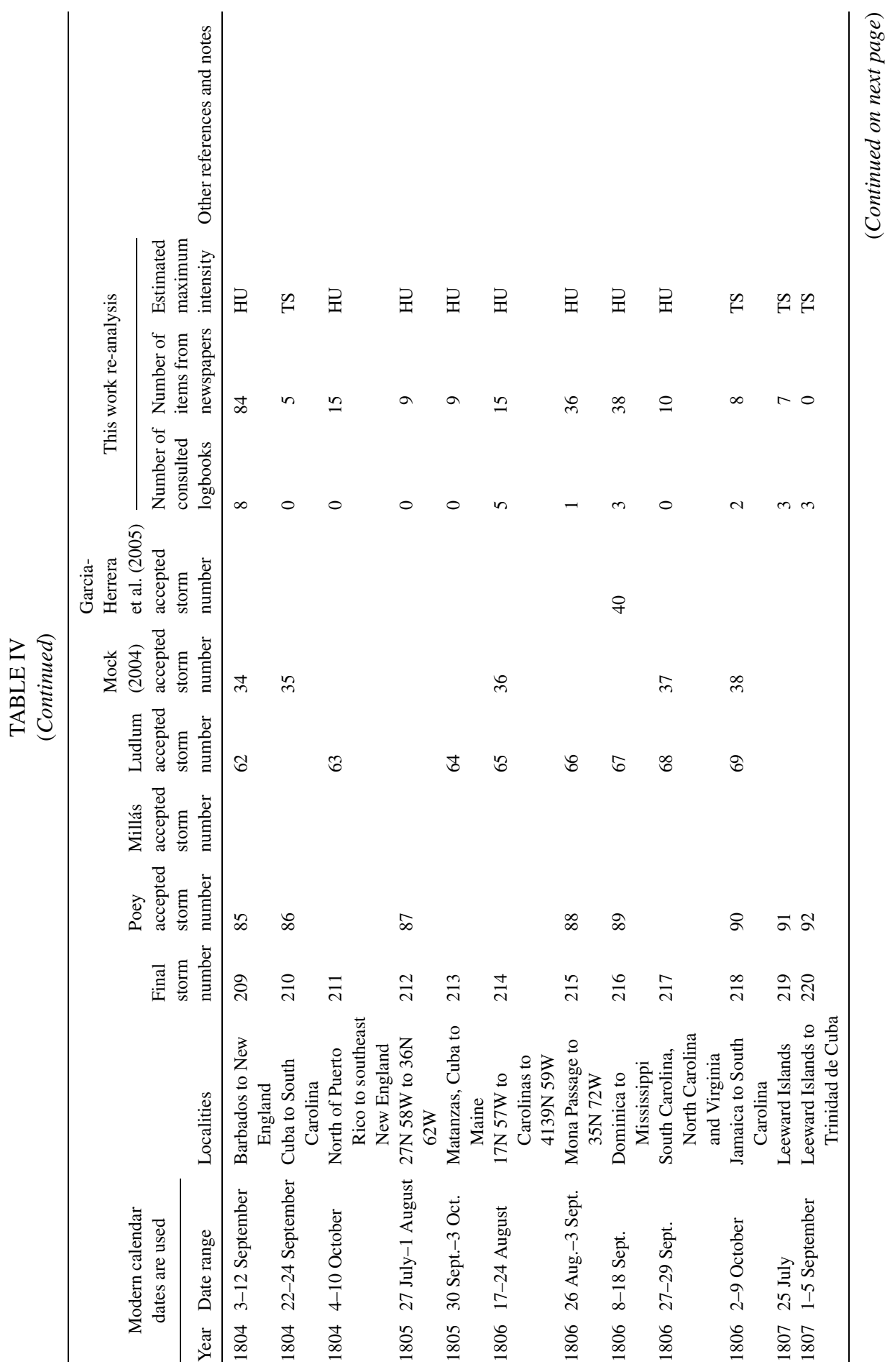


REASSESSMENT OF HISTORICAL ATLANTIC TROPICAL CYCLONES

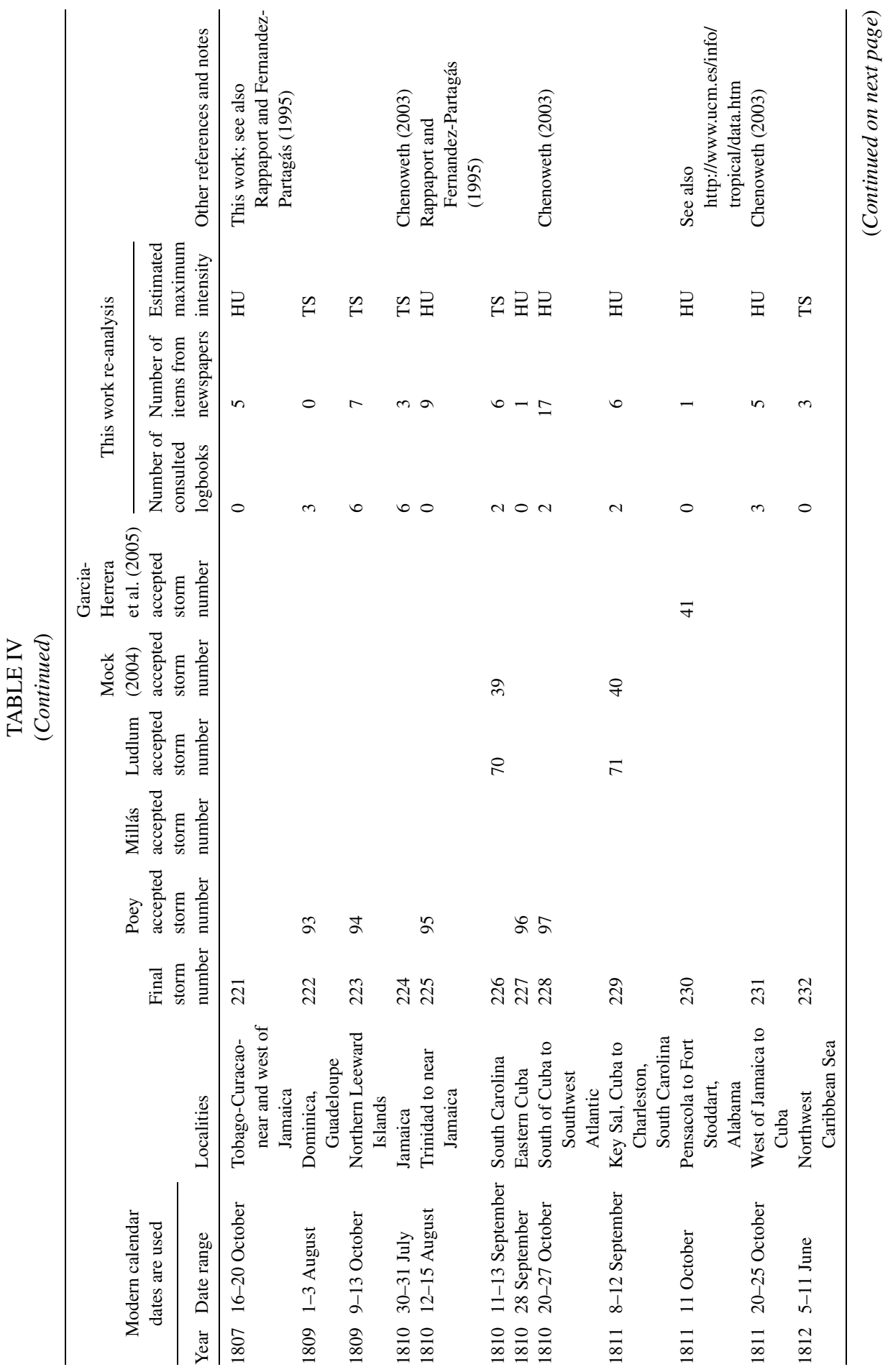


M. CHENOWETH

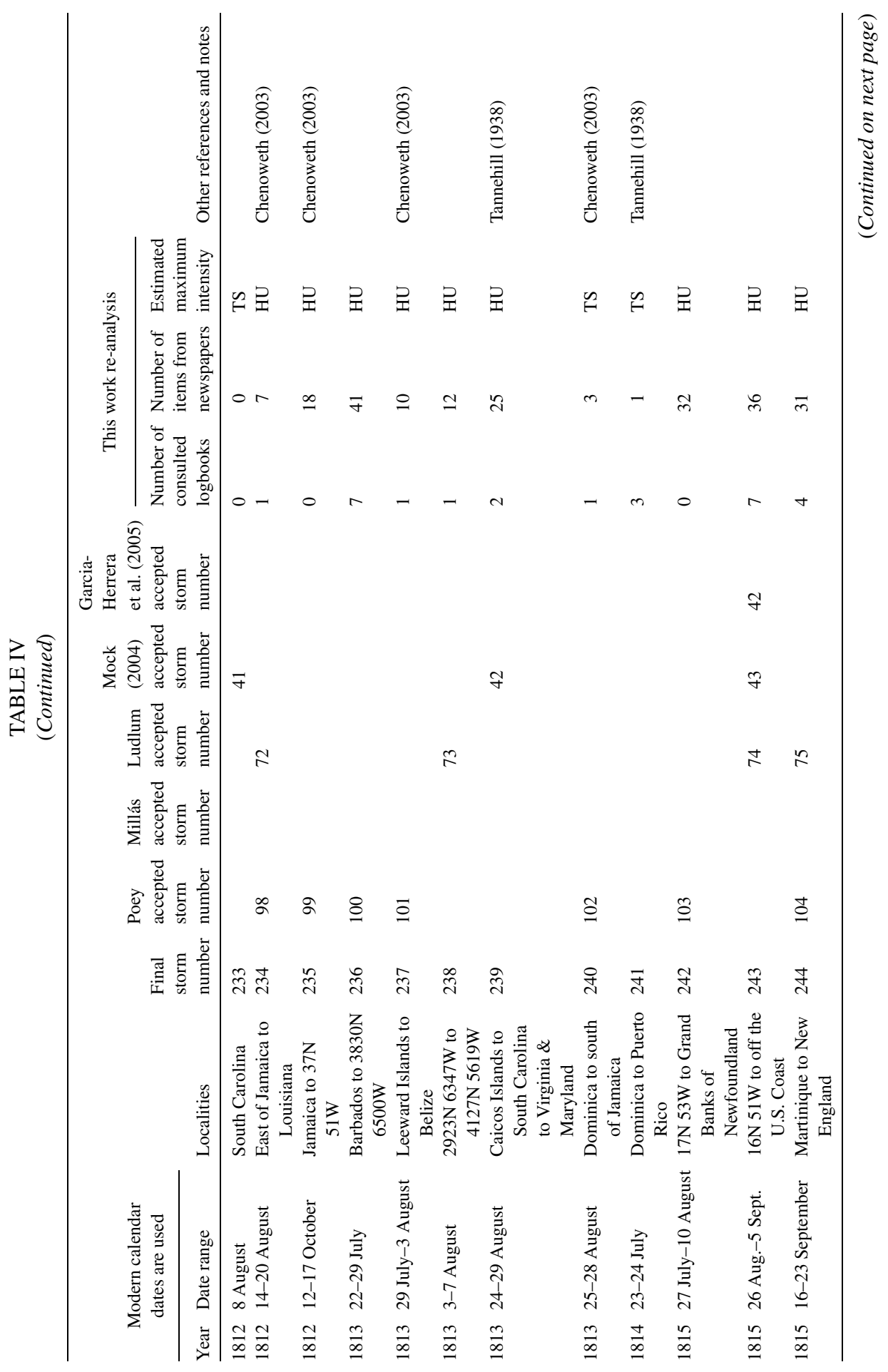


REASSESSMENT OF HISTORICAL ATLANTIC TROPICAL CYCLONES

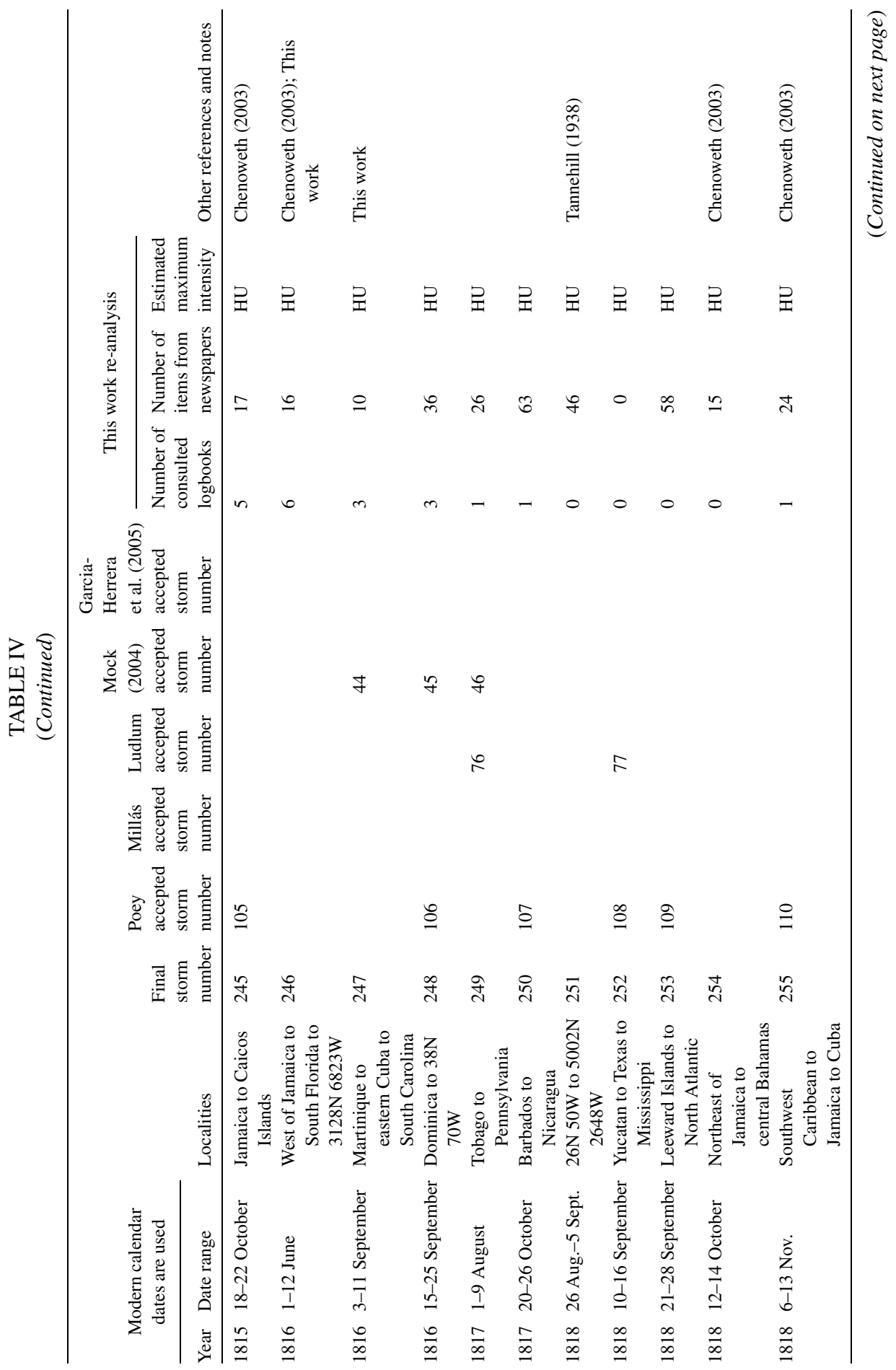


M. CHENOWETH

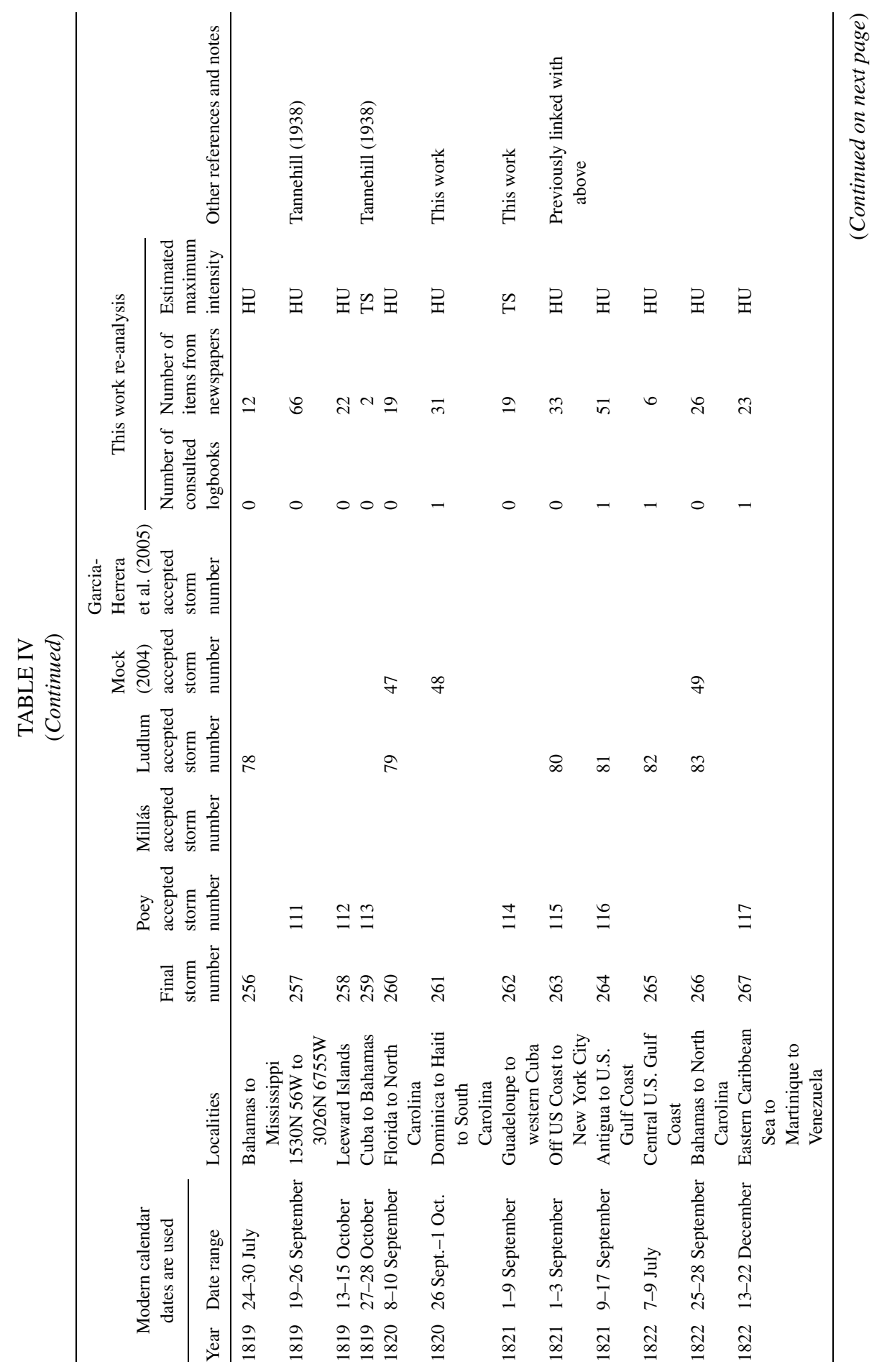


REASSESSMENT OF HISTORICAL ATLANTIC TROPICAL CYCLONES

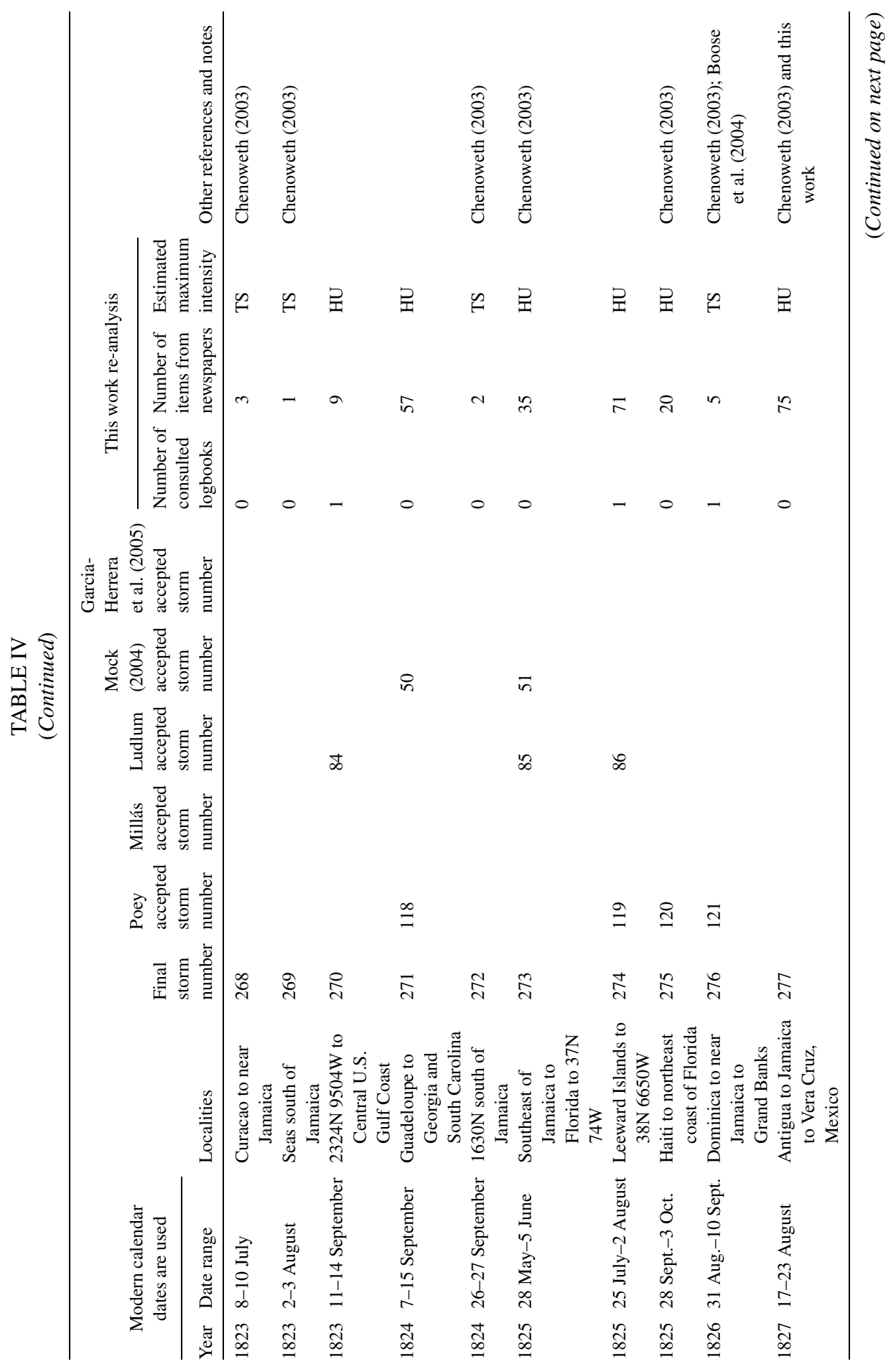


M. CHENOWETH

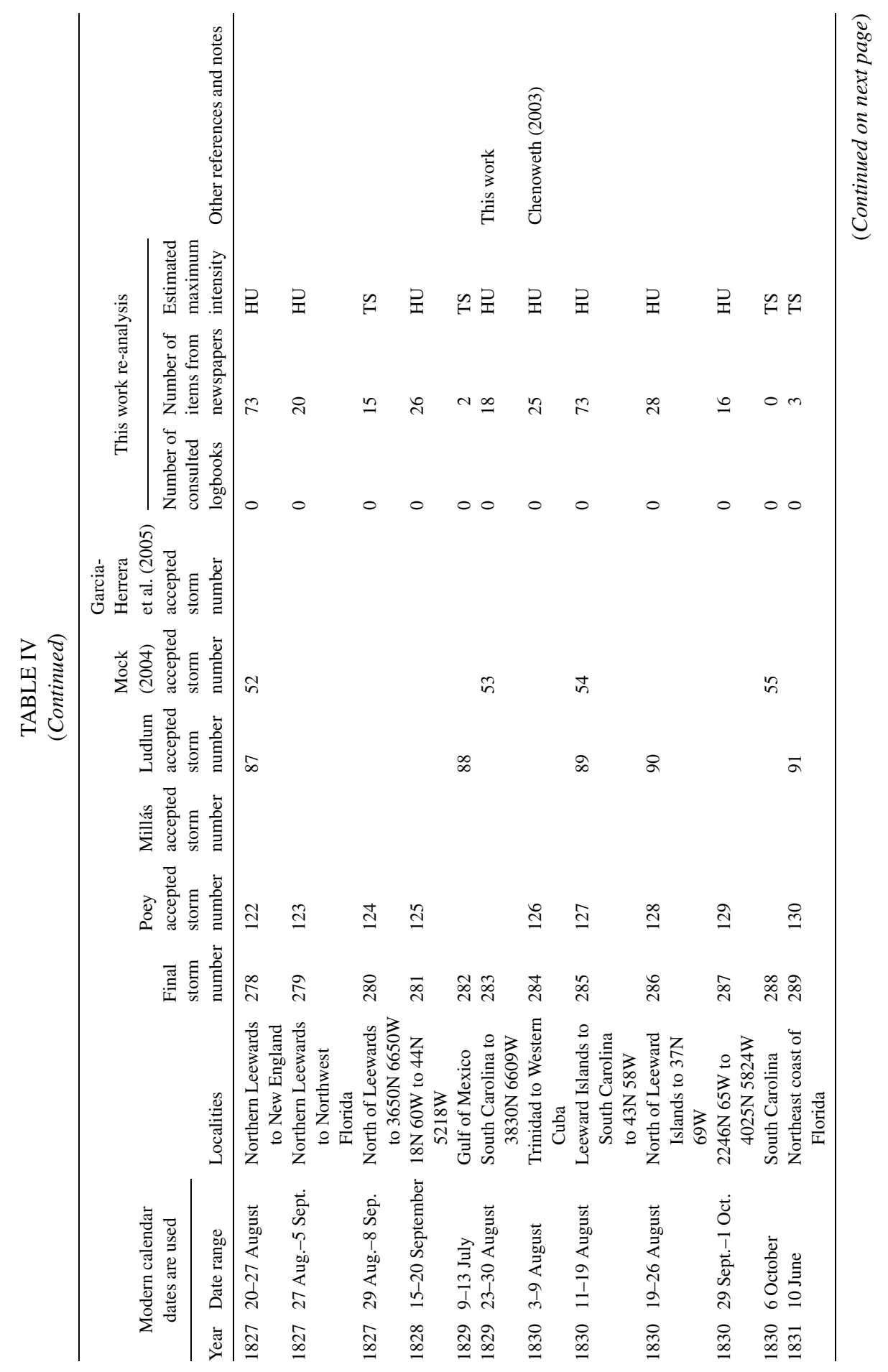


REASSESSMENT OF HISTORICAL ATLANTIC TROPICAL CYCLONES

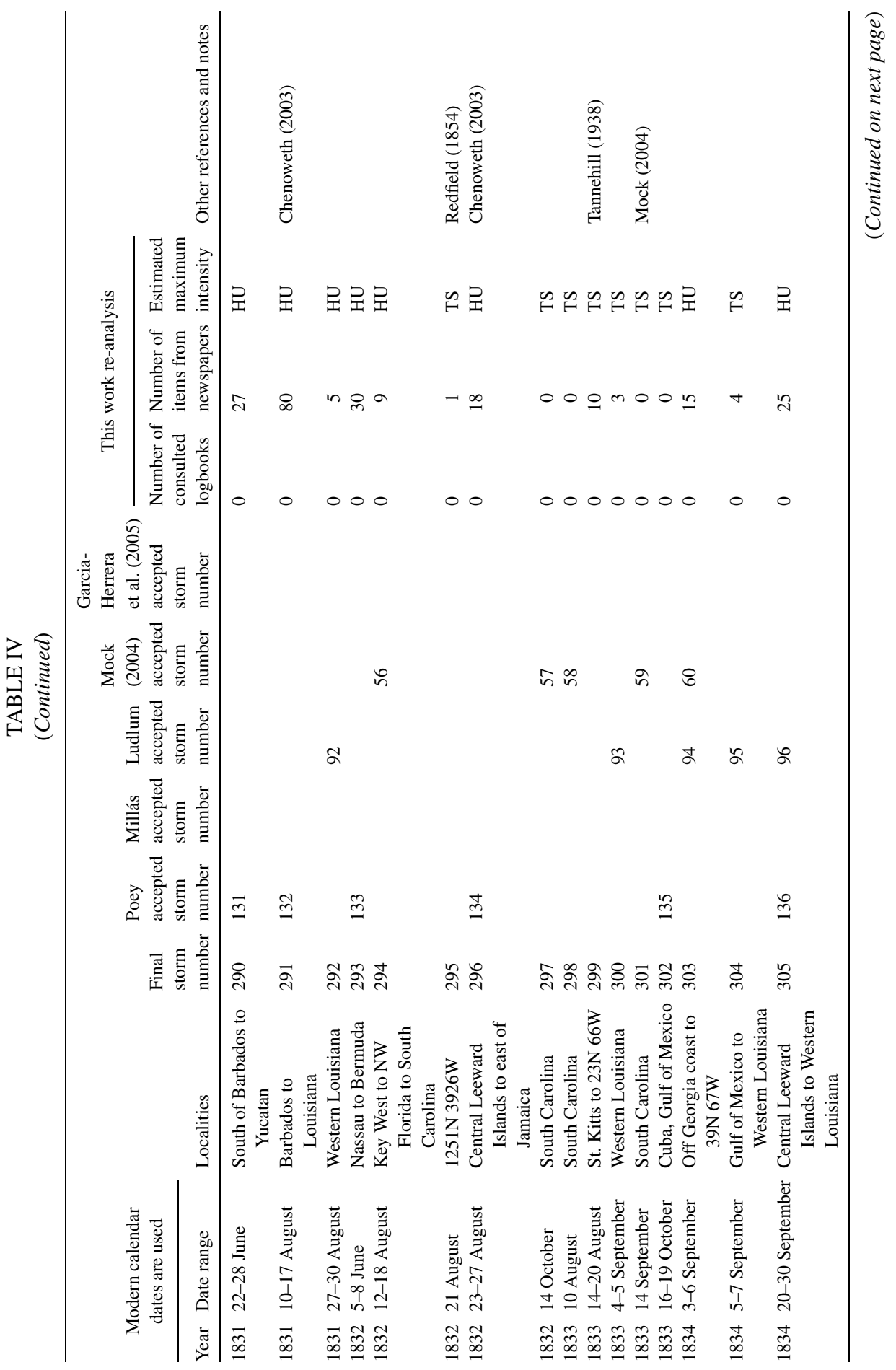


M. CHENOWETH

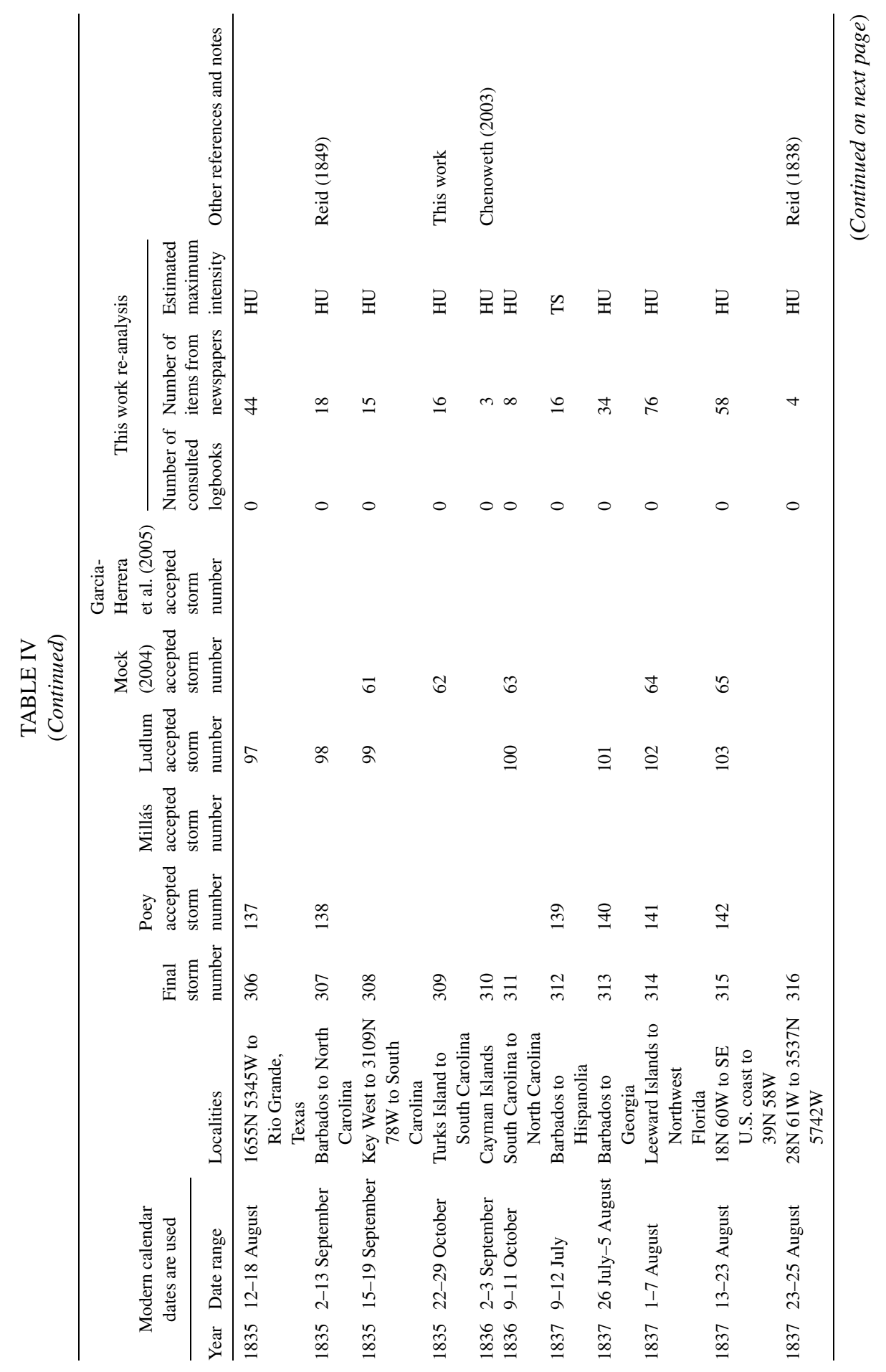


REASSESSMENT OF HISTORICAL ATLANTIC TROPICAL CYCLONES

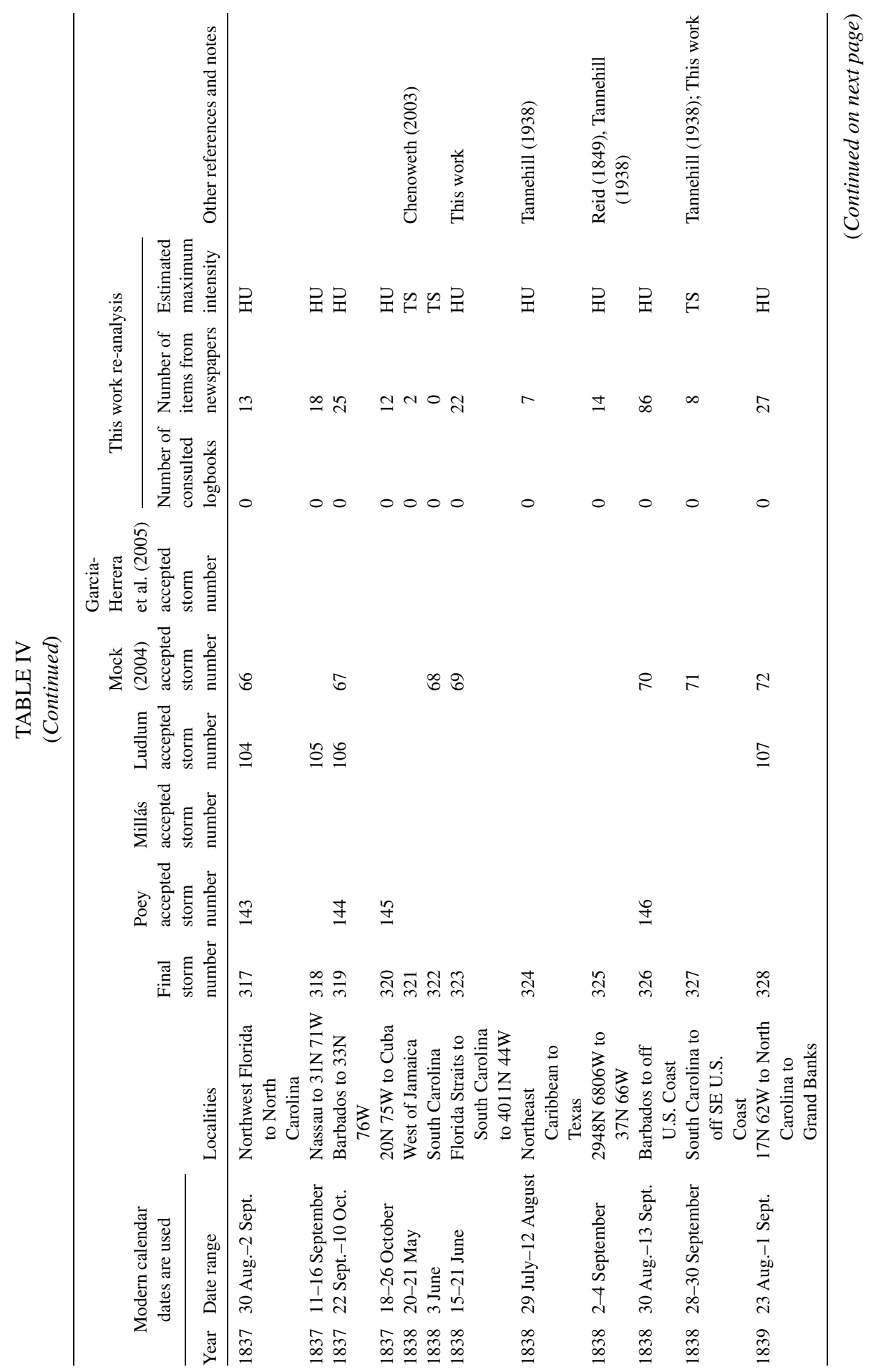


M. CHENOWETH

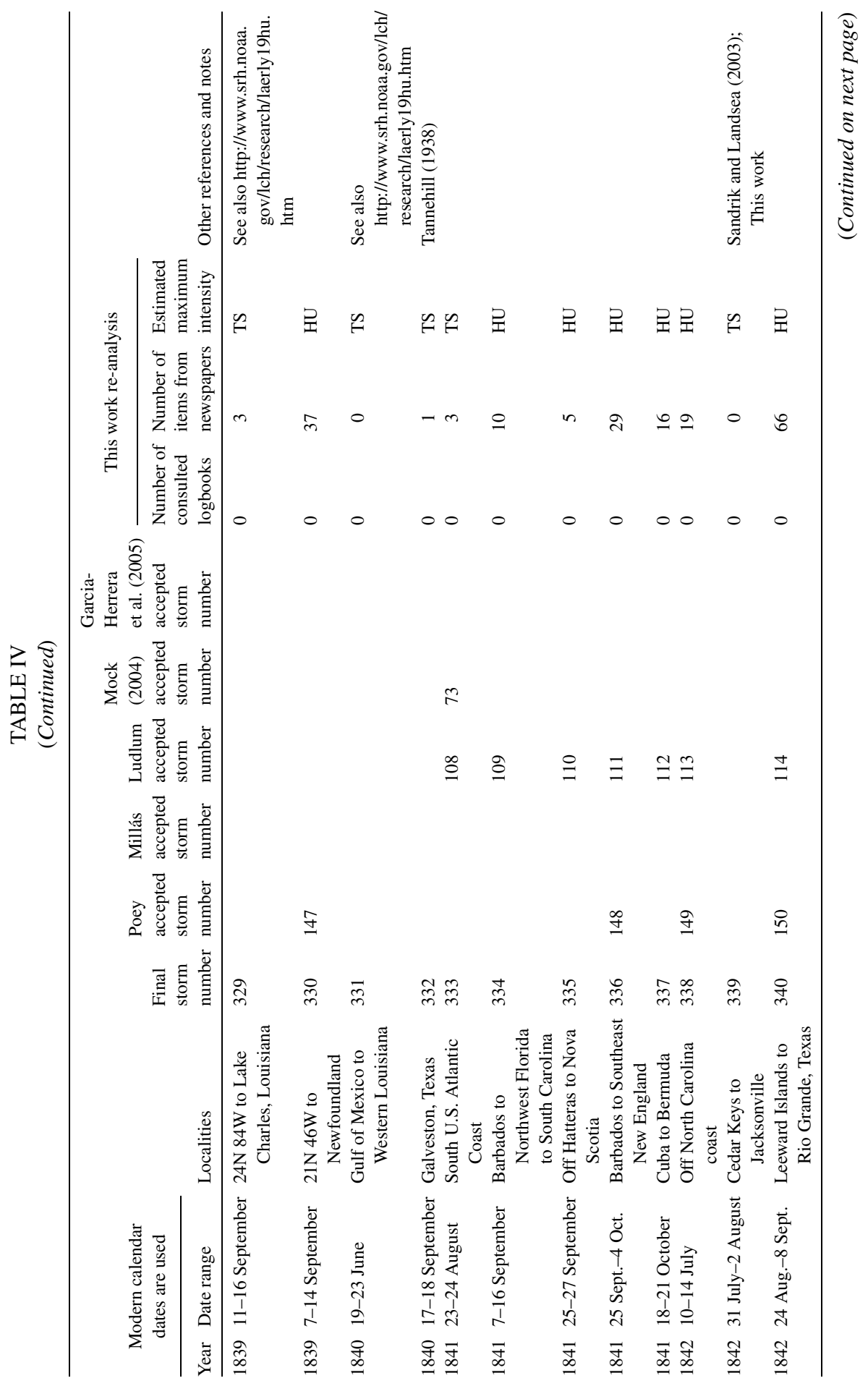


REASSESSMENT OF HISTORICAL ATLANTIC TROPICAL CYCLONES

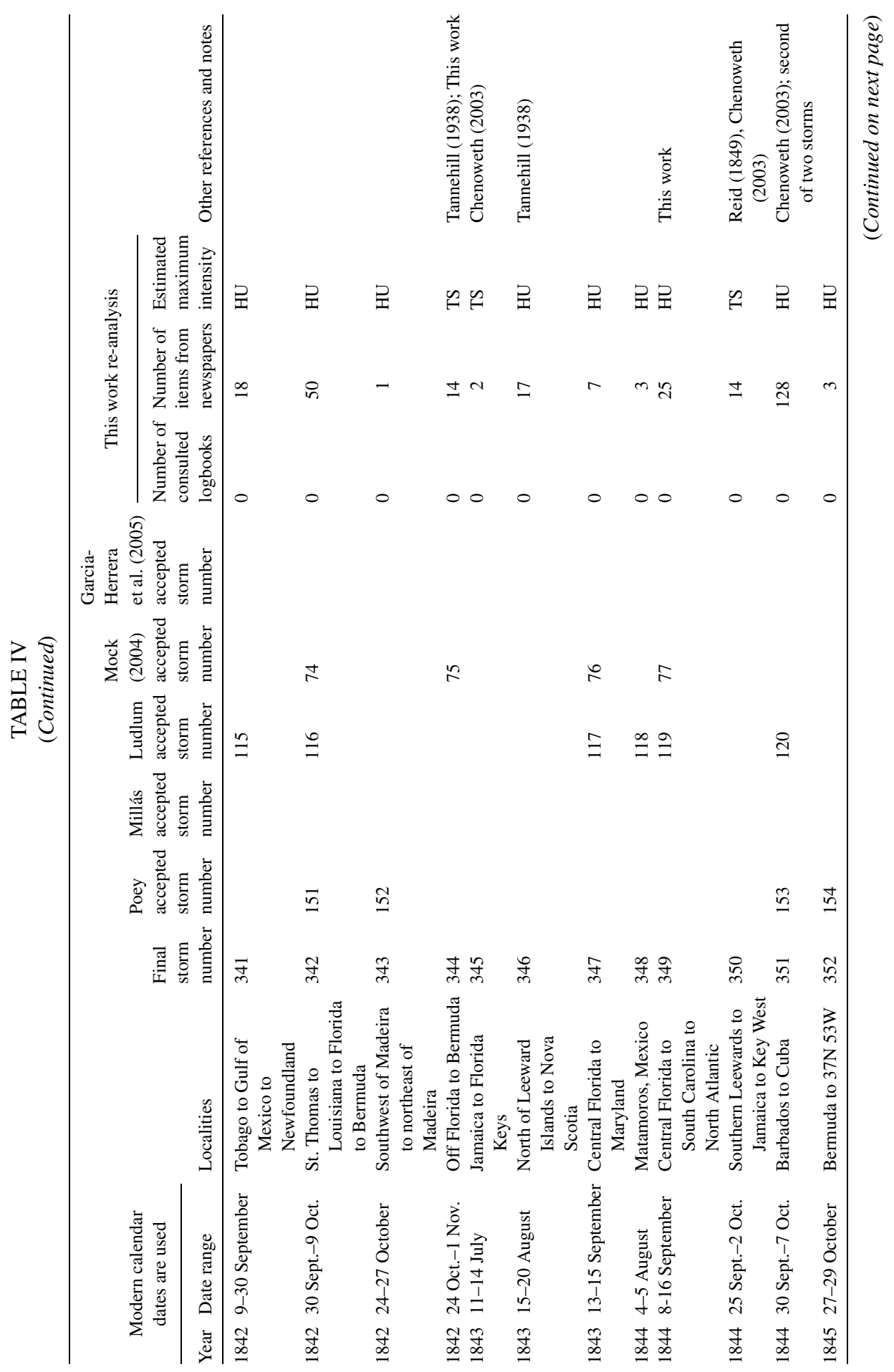


M. CHENOWETH

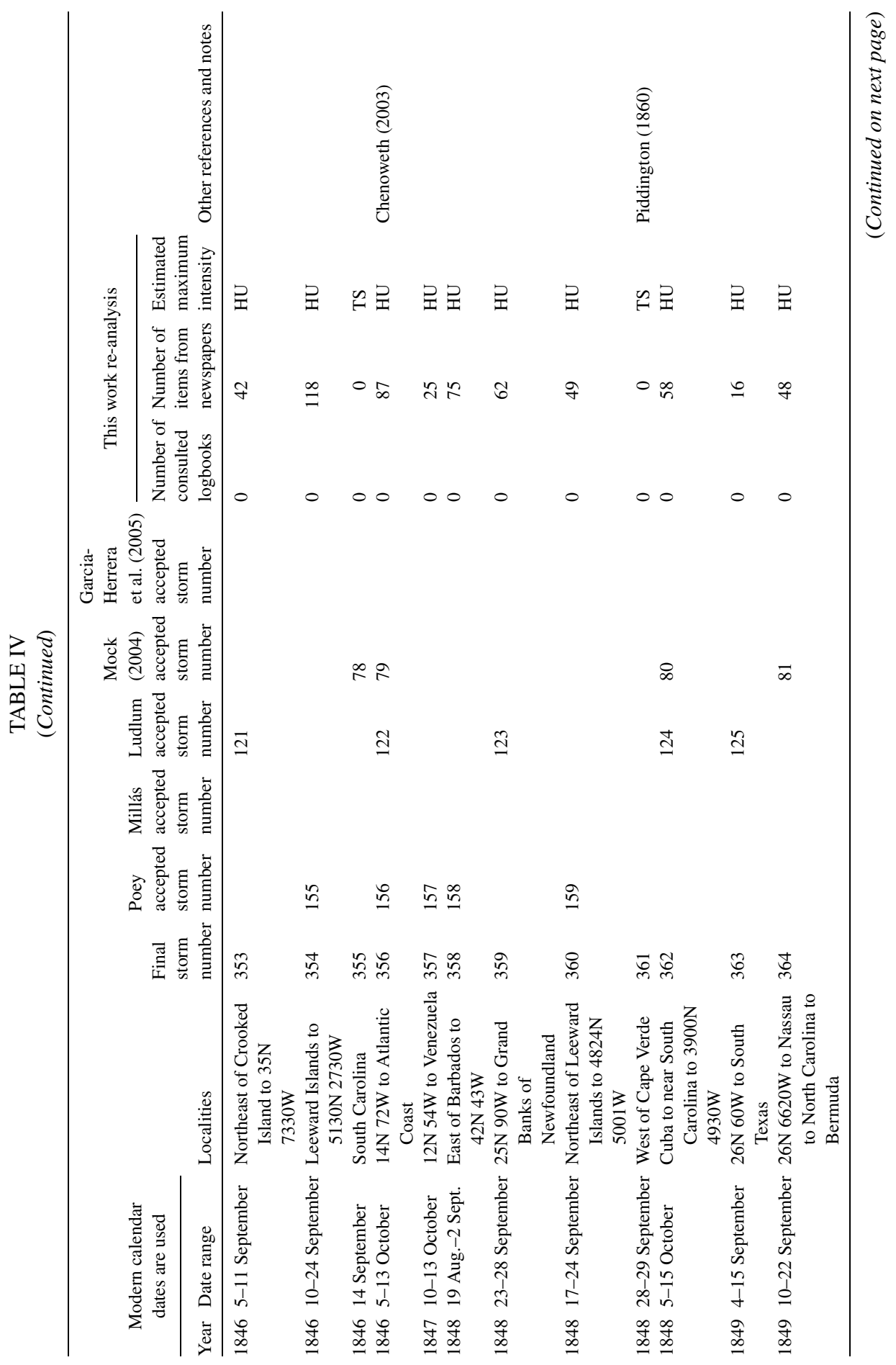


REASSESSMENT OF HISTORICAL ATLANTIC TROPICAL CYCLONES

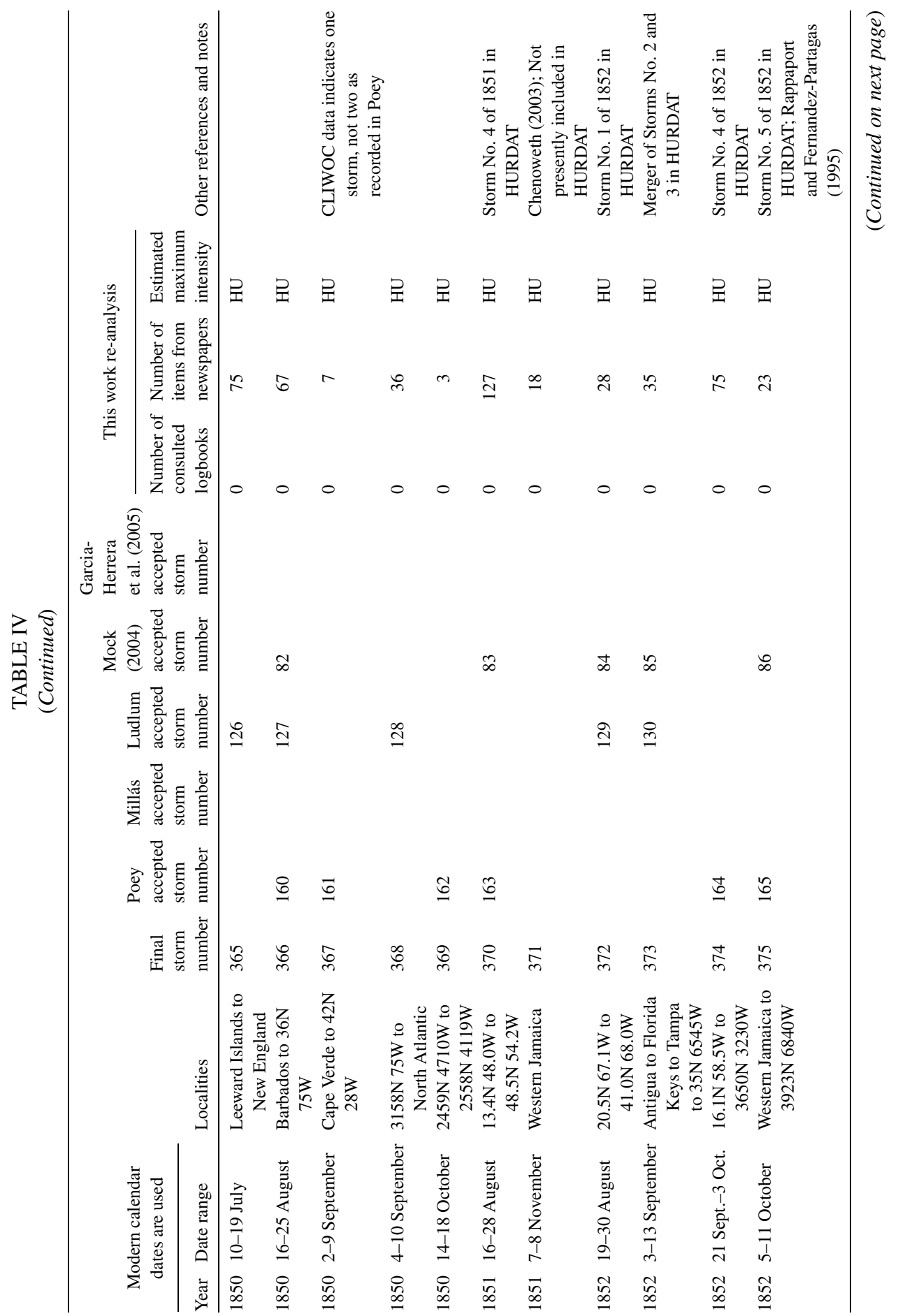


M. CHENOWETH

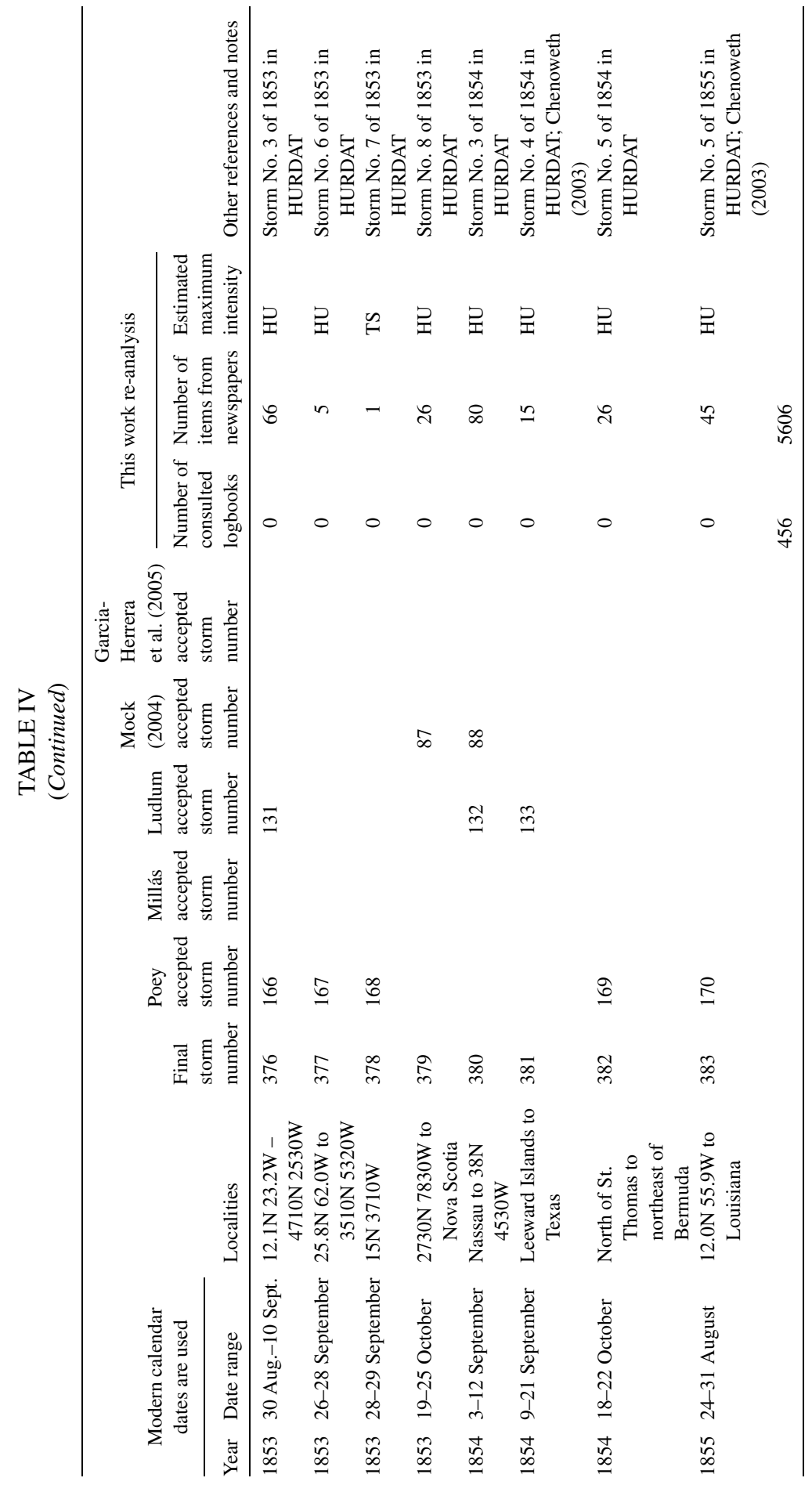


The records of Poey (1855), Millás (1968), Ludlum (1963), Mock (2004) and Garcia-Herrera et al. (2005) in Table IV, along with previous and new work by this author, provides a "comprehensive" chronology of Atlantic basin storms through 1850 and a partial list for 1851-1855 which should be used in combination with the current HURDAT lists for 1851-2004 (Landsea et al., 2004). This final "comprehensive" chronology lists all of the published information available as of 2005 and consists of 383 published, independently-confirmed tropical cyclones for 1700-1855. It should replace all previous hurricane chronologies prior to 1851 . The most complete list of post-1850 Atlantic tropical cyclones is found in HURDAT but Table IV adds to and corrects HURDAT. The "comprehensive" chronology in Table IV should now finally replace Poey's list, and succeeding chronologies published since that time for years prior to 1851. Tables I, III and IV are also included on the author's web site hosted at http://www.aoml.noaa.gov/hrd/hurdat/chenowethcc05.pdf.

\section{Conclusions and Summary}

A new analysis of Atlantic basin tropical cyclones for the period 1700-1855 was compared against the previously published chronology of Poey (1855). Thirty-seven percent of the entries were found to be in error and rejected. Since the Poey record has been used in lists of Atlantic basin tropical cyclones for nearly 150 years, this error rate makes these lists of little use for serious climatological research. Other historical records of tropical cyclones by Millás (1968) and Ludlum (1963) were also compared with the new chronology. Millás was found to have continued to propagate errors from Poey's list, corrected others, and added both new storms and new errors. Ludlum was more successful in correctly dating and identifying tropical cyclones based largely on his use of primary sources, and searching for multiple independent sources before accepting them. Millás, in turn, largely read the secondary literature, which is often flawed. Mock (2004) and Garcia-Herrera et al. (2005) have also made important contributions to the chronology from original documents in archives in South Carolina and Spain.

The new chronology, including 383 unique storms from 1700 through 1855, should now replace all previous compilations of pre-1851 Atlantic basin tropical cyclones, as it is based on the most exhaustive search of primary documents ever done for the basin as a whole. Other research projects, such as that of the Climate of the World's Oceans (CLIWOC) (www.nmm.ac.uk and the CLIWOC homepage at http://www.ucm.es/info(reclido/en/home-en.htm), provide additional information on ships' logbooks and climate reconstruction, that is of interest for tropical cyclone reconstruction. Readers interested in post-1850 records should consult the HURDAT data set (Landsea et al., 2004), Chenoweth (2003) and Mock (2004) as well as Table IV of this work. The inclusion of this data into HURDAT is planned. 


\section{CHENOWETH}

\section{Acknowledgments}

Professor Cary Mock, Department of Geography, University of South Carolina at Columbia generously provided his newly-compiled list of South Carolina historical tropical cyclones for use in this work. The author also acknowledges the three referees who provided valuable suggestions and critical commentary.

\section{References}

Boose, E. R., Serrano, M. I., and Foster, D. R.: 2004, 'Landscape and regional impacts of hurricanes in Puerto Rico', Ecological Monographs 74(2), 335-352.

Chenoweth, M.: 1996, 'Ships' logbooks and "The year without a summer"', Bull. Amer. Meteor. Soc. 77, 2077-2094.

Chenoweth, M.: 1998, 'The early 19th century climate of the Bahamas and a comparison with 20th century averages', Climatic Change 40, 577-603.

Chenoweth, M.: 2003, 'The 18th century climate of Jamaica, derived from the journals of Thomas Thistlewood, 1750-1786', Transactions of the American Philosophical Society 93(2), Philadelphia, 153pp.

Chenoweth, M. and Landsea, C.: 2004, 'The San Diego hurricane of 2 October 1858', Bull. Amer. Meteor. Soc. 85, 1689-1697.

Donnelly, J. P., Smith Bryant, S., Butler, J., Dowling, J., Fan, L., Hausmann, N., Newby, P., Shuman, B., Stern, K., Westover, K., and Webb III, T., 2001: '700 yr sedimentary record of intense hurricane landfalls in southern New England', GSA Bulletin 113(6), 714-727.

Du Tertre, J. B.: 1667, Historie Générale des Antilles habitées par les François, Vol. II, Paris.

Edwards, B.: 1805, The History, Civil and Commercial, of the British Colonies in the West Indies, vol. 1, J. Humphreys, Philadelphia.

Elsner, J. B. and Kara, A. B.: 1999, Hurricanes of the North Atlantic: Climate and Society, Oxford University Press, New York.

Evans, "Stormy Jack", 1848: "A chronological list of the hurricanes which have occurred in the West Indies since the year 1493', Nautical Magazine, pp. 397, 453, 524.

Fernandez-Partagás, J. and Diaz, H. F.: 1995a, A Reconstruction of Historical Tropical Cyclone Frequency in the Atlantic from Documentary and Other Historical Sources, 1851 to 1880. Part I: 1851-1870, Climate Diagnostics Center, Environmental Research Laboratories, National Oceanic and Atmospheric Administration, Boulder, CO. Available at http://www.aoml.noaa.gov/hrd/ hurdat/hurdat_pub.html

Fernandez-Partagás, J. and Diaz, H. F.: 1995b, A Reconstruction of Historical Tropical Cyclone Frequency in the Atlantic from Documentary and Other Historical Sources, 1851 to 1880. Part II: 1871-1880, Climate Diagnostics Center, Environmental Research Laboratories, National Oceanic and Atmospheric Administration, Boulder, CO. Available at http://www.aoml.noaa.gov/hrd/ hurdat/hurdat_pub.html

Fernandez-Partagás, J. and Diaz, H. F.: 1996a, A Reconstruction of Historical Tropical Cyclone Frequency in the Atlantic from Documentary and Other Historical Sources, Part III: 18811890, Climate Diagnostics Center, Environmental Research Laboratories, National Oceanic and Atmospheric Administration, Boulder, CO. Available at http://www.aoml.noaa.gov/hrd/hurdat/ hurdat_pub.html

Fernandez-Partagás, J. and Diaz, H. F.: 1996b, A Reconstruction of Historical Tropical Cyclone Frequency in the Atlantic from Documentary and Other Historical Sources. Part IV: 18911900, Climate Diagnostics Center, Environmental Research Laboratories, National Oceanic and 
Atmospheric Administration, Boulder, CO. Available at http://www.aoml.noaa.gov/hrd/hurdat/ hurdat_pub.html

Fernandez-Partagás, J. and Diaz, H. F.: 1996c, 'Atlantic Hurricanes in the second half of the Nineteenth Century', Bull. Amer. Meteor. Soc. 77, 2899-2906.

Fernandez-Partagás, J. and Diaz, H. F.: 1997, A Reconstruction of Historical Tropical Cyclone Frequency in the Atlantic from Documentary and Other Historical Sources. Part V: 19011908, Climate Diagnostics Center, Environmental Research Laboratories, National Oceanic and Atmospheric Administration, Boulder, CO. Available at http://www.aoml.noaa.gov/hrd/hurdat/ hurdat_pub.html

Fernandez-Partagás, J. and Diaz, H. F.: 1999, A Reconstruction of Historical Tropical Cyclone Frequency in the Atlantic from Documentary and Other Historical Sources. Part VI: 19091910, Climate Diagnostics Center, Environmental Research Laboratories, National Oceanic and Atmospheric Administration, Boulder, CO. Available at http://www.aoml.noaa.gov/hrd/hurdat/ hurdat_pub.html

Garcia-Herrera, R., Rubio, F., Wheeler, D., Hernández, E., Prieto, M. R., and Gimeno, L.: 2004, 'The use of Spanish and British documentary sources in the investigation of Atlantic hurricanes in historical times', in Murnane, R. J. and Liu, K.-B. (eds.), Hurricanes and Typhoons: Past, Present, and Future, Columbia University Press, 149-176.

Garcia-Herrera, R., Gimeno, L., Ribera, P., and Hernández, E.: 2005, 'New records of Atlantic hurricanes from Spanish documentary sources', Journal of Geophysical Research - Atmospheres 110 D03109, doi: 10.1029/2004JD005272.

Johnston, A. K.: 1855, The Physical Atlas of Natural Phenomena, William Blackwood and Sons, Edinburgh.

Landsea, C. W., Anderson, C., Charles, N., Dunion, J., Clark, G., Fernandez-Partagás, J., Hungerford, P., Neumann, C., and Zimmer, M.: 2004, 'The Atlantic hurricane database re-analysis project: Documentation for the 1851-1910 alterations and additions to the HURDAT database', in Murnane, R. J. and Liu, K.-B. (eds.), Hurricanes and Typhoons: Past, Present, and Future, Columbia University Press, pp. 177-221.

Liu, K.-B.: 2004, 'Paleotempestology: Geographic solutions to hurricane hazard assessment and risk prediction', in Janelle, D., Warf, B. and Hansen, K. (eds.), WorldMinds: Geographical Perspectives on 100 Problems, Kluwer, pp. 443-448.

Liu, K.-B. and Fearn, M. L.: 2000, 'Reconstruction of prehistoric landfall frequencies of catastrophic hurricanes in northwestern Florida from lake sediment records', Quaternary Research 54, 238245.

Long, E.: 1774, The History of Jamaica, Vol. III (Arno Press 1972 Reprint Edition of 1774 Original).

Ludlum, D. M.: 1963, Early American Hurricanes, 1492-1870, Boston, American Meteorological Society.

Malmquist, D. L.: 1998, 'ENSO, tropical cyclones, and the insurance industry', ENSO Signal 9, 4-6.

Millás, C. J.: 1968, Hurricanes of the Caribbean and Adjacent Regions, 1492-1800, Academy of the Arts and Sciences of America, Miami.

Mock, C. J.: 2002, 'Documentary records of past climate and tropical cyclones from the southeastern united states', PAGES News 10, 20-21.

Mock, C. J.: 2004, 'Tropical cyclone reconstructions from documentary records: Examples for South Carolina, United States', in Murnane, R. J. and Liu, K.-B. (eds.), Hurricanes and Typhoons: Past, Present, and Future, Columbia University Press, pp. 121-148.

Moreau de Jonnès, A.: 1822, 'Sur les Ouragans des Antilles, avec un tableau chronologique de ceux qui eurent lieu', Histoire Physique des Antilles Francaises 1, 346.

Pasch, R. J., Lawrence, M. B., Avila, L. A., Beven, J. L., Franklin, J. L., and Stewart, S. R.: 2004, 'Atlantic hurricane season of 2002', Monthly Weather Review 132, 1829-1859. 


\section{CHENOWETH}

Piddington, H.: [1848] 1860, The Sailor's Horn-Book for the Law of Storms; Being a Practical Exposition of the Theory of the Law of Storms, and its Uses to Mariners of all Classes in all Parts of the World, Shewn by Transparent Storm Cards and Useful Lessons. 2nd edition, London.

Poey, A.: 1855, 'A chronological table, comprising 400 cyclonic hurricanes which have occurred in the West Indies in the North Atlantic within 362 years, from 1493 to 1855', Journal of the Royal Geographical Society 25, 291-328.

Rappaport, E. N. and Fernandez-Partagás, J.: 1995, The Deadliest Atlantic Tropical Cyclones, 14921995, NOAA Technical Memorandum NWS NHC 47.

Rappaport, E. N. and Ruffman, A.: 1999, 'The catastrophic 1775 hurricane(s): the search for data and understanding', in Preprints, 23rd Conference on Hurricanes and Tropical Meteorology, American Meteorological Society, Boston, MA, pp. 787-790.

Redfield, W.: 1831, 'Remarks on the prevailing storms of the Atlantic coast of the North American States', Amer. J. of Science and Arts 20, 17-51.

Redfield, W.: 1854, 'On the first hurricane of September 1853, in the Atlantic; with a chart; and notice of other storms', Amer. Journ. Sci. 18, 1-18, 176-190.

Reid, W.: 1838, An Attempt to Develop the Law of Storms by Means of Facts, Arranged According to Place and Time; Hence to Point out a Cause for the Variable Winds, with a View to Practical Use in Navigation, John Weale, London.

Reid, W.: 1849, The Progress of the Development of the Law of Storms and of Variable Winds, with the Practical Application of the Subject to Navigation, John Weale, London.

Rogers, P.: 2003, 'Defoe and the great storm of 1703', Times Literary Supplement, July 4, 14-15.

Sandrik, A. and Landsea, C. W.: 2003, 'Chronological listing of tropical cyclones affecting North Florida and Coastal Georgia, 1565-1899', NOAA Technical Memorandum NWS SR224, Southern Region, National Weather Service. Available at http://www.aoml.noaa.gov/hrd/ Landsea/history.

Schomburgk, R. H.: 1848, The History of Barbados, Longman, Brown, Green, and Longmans, London.

Southey, T.: [1827] 1968, Chronological History of the West Indies, Cass Library of West Indian Studies, No. 4, Frank Cass and Co., Ltd., London, Vol. 3.

Tannehill, I.: [1938] 1952, Hurricanes, 8th ed., Princeton University Press, Princeton.

Teachout, T.: 1982, Beware the Hurricane!, Island Press Limited, Hamilton, Bermuda.

Walsh, R. and Reading, A.: 1991, 'Historical changes in tropical cyclone frequency within the Caribbean since 1500', in Glaser, R. and Walsh, R. (eds.), Würzburger Geographische Arbeiten 80, 199-240.

(Received 6 August 2004; in revised form 19 July 2005) 